\title{
Nordic initiatives to abate methane emissions
}

A cathalogue of best practices

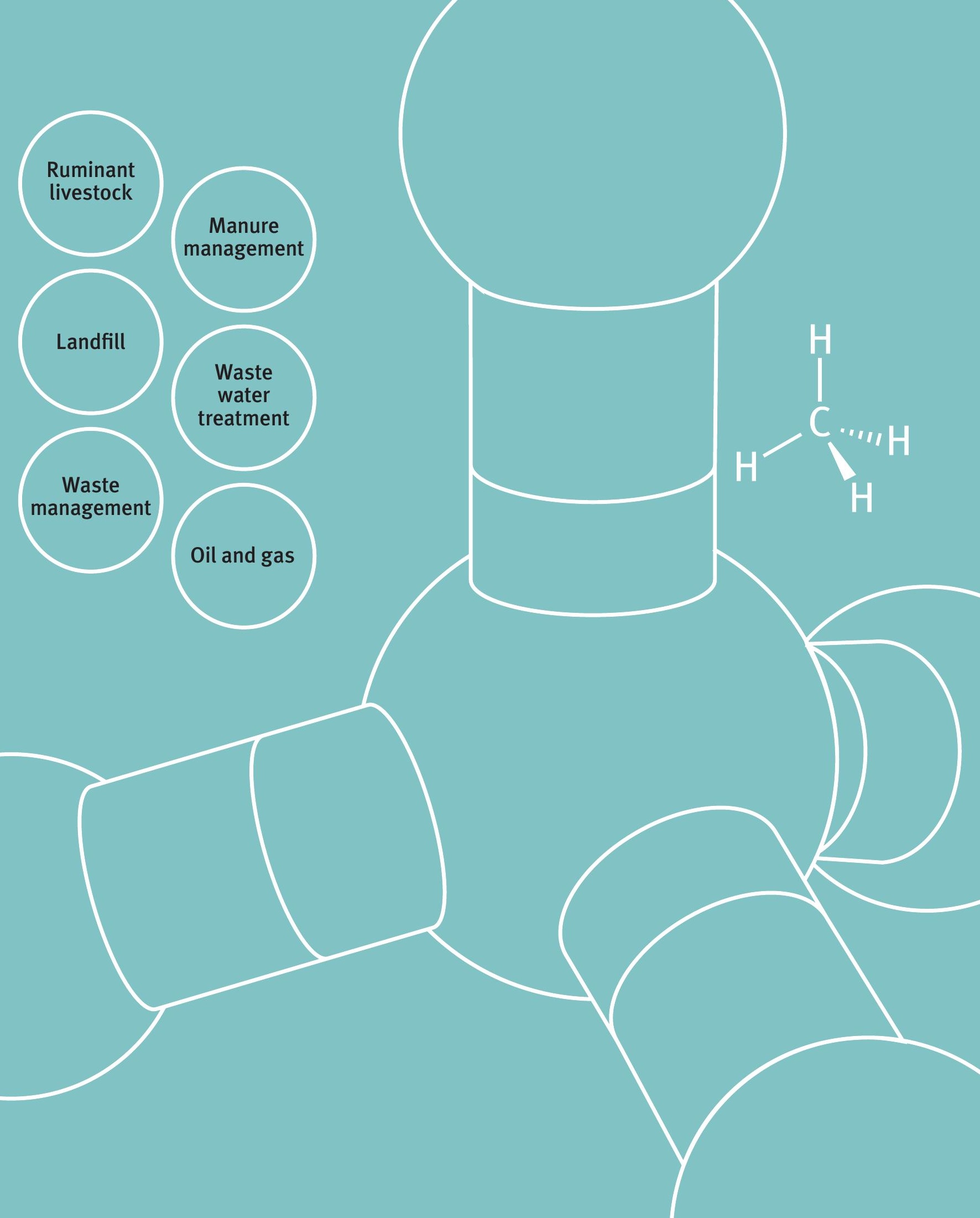

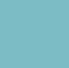




\section{Nordic initiatives to abate methane emissions}

ISBN 978-92-893-3774-8 (PRINT)

ISBN 978-92-893-3775-5 (PDF)

http://dx.doi.org/10.6027/ANP2014-741

ANP 2014:741

(C) Nordic Council of Ministers 2014

Layout: Erling Lynder

Copies: 100

Print: Rosendahl - Schultz Grafisk

Printed in Denmark

This publication has been published with financial support by the Nordic Council of Ministers. However, the contents of this publication do not necessarily reflect the views, policies or recommendations of the Nordic Council of Ministers.

www.norden.org/en/publications

\section{RAMBOLL}

Nordic Council of Ministers

Ved Stranden 18

DK-1061 Copenhagen $\mathrm{K}$

Phone (+45) 33960200

www.norden.org

\section{Nordic co-operation}

Nordic co-operation is one of the world's most extensive forms of regional collaboration, involving Denmark, Finland, Iceland, Norway, Sweden, and the Faroe Islands, Greenland, and Åland.

Nordic co-operation has firm traditions in politics, the economy, and culture. It plays an important role in European and international collaboration, and aims at creating a strong Nordic community in a strong Europe.

Nordic co-operation seeks to safeguard Nordic and regional interests and principles in the global community. Common Nordic values help the region solidify its position as one of the world's most innovative and competitive. 


\section{Nordic initiatives to abate methane emissions}

1. Background and aim 8

1.1 Background 8

1.2 Purpose and aim of the project 9

1.3 Organisation 9

1.4 Method of work 10

1.4.1 Selection criteria $\quad 11$

2. Methane emissions from different sectors 13

2.1 Statistics and categorizing 13

2.1.1 Summary statistics and categorizing 16

2.2 Description of each selected sector and sources of methane emissions $\quad 17$

2.2.1 Ruminant livestock - enteric fermentation $\quad 17$

2.2.2 Manure management 19

2.2.3 Landfill 20

2.2.4 Waste water treatment 20

2.2.5 Waste management 21

2.2.6 Oil and gas systems $\quad 22$

3. Conditions and criteria for calculations 25

3.1 System boundaries and conditions 25

3.2 Cost effectiveness 25

4. The Catalogue 29

4.1 Production of milk and meat with high productivity combined with high environmental awareness. 30

4.2 Large scale biogas production from manure, organic waste and sewage sludge for electricity and heat production 
4.3 Small scale biogas production from manure, potatoes and flour for electricity and heat production 38

4.4 Biogas production from solid horse manure 41

4.5 Small scale local biogas production with gas distribution pipelines to collective upgrading plant $\quad 45$

4.6 Landfill gas collection system and upgrading 50

4.7 Low- tech bio cover system 54

4.8 Micrometeorological methods for efficient recovery of landfill gas and control of emissions 57

4.9 Using landfill gas with low methane content to a further extent with an stirling engine $\quad 60$

4.10 Thermal hydrolyses of sludge for anaerobic digestion 63

4.11 Sealed tanks for digested sludge 66

4.12 Large scale anaerobic digestion and pre-treatment of organic waste from households and slaughter house waste

4.13 Voluntary agreement for anaerobic digestion and gas upgrading plants

4.14 Hydrocarbon blanketing to eliminate VOC emissions from cargo tanks at FPSOs 


\section{Authors preface}

This report aims to direct the reader to some of the many good examples of methane emission abatement measures implemented in the Nordic countries.

The target group is broad, which is why we have included both an easy introduction as well as a more thorough description for the more experienced reader. For more detailed information and questions contact information can be found under each case.

The Nordic Climate and Air Pollution Group (KoL) has recognized that the work with reducing not only carbon dioxide but also other greenhouse gases with shorter lifetime is of great importance in order to minimize negative effects associated with climate change. We would like to thank the Nordic Climate and Air Pollution Group for showing us the confidence to assign this report.

We would like to give a special thanks to all the plant owners, project owners and experts who have contributed with their knowledge and time during the compilation of this catalogue of good examples to abate methane gas emissions.

We are happy and proud to present some of the best mitigation practices to abate methane gas emissions within the Nordic countries. Our hope is that this report will serve as a useful aid in the efforts to reduce emissions of short-lived climate pollutants, in particular methane.

Stockholm, 17 October 2014

Cajsa Hellstedt
Jenny Cerruto
Maria Nilsson
Michael McCann




\section{Summary}

As the effect of climate change become more acute there is growing recognition, within the scientific and policy community that ongoing efforts to address climate change should also focus on near-term actions to reduce short lived pollutants such as methane. Carbon dioxide is still unquestionably the main force for anthropogenic global warming but scientists estimate that substances with shorter atmospheric lifetime, such as methane, account for $30-40 \%$ of the human induced warming to date. Reduction of methane emission is thus recognised to result in important but shorter-term benefits.

In order to spread some knowledge of best practice and efficient technical measures on how to abate methane emission, The Nordic Climate and Air Pollution Group (KoL) recently decided to publish a catalogue of "Nordic initiatives to abate methane emissions". Ramböll received the assignment to compile this catalogue in January 2014.

The target group for the report is wide, ranging from policy makers responsible for a top-level approach to concerned plant and project owners.

The catalogue describes a number of examples of methane abatement measures in six different sectors (Table 1). The selection of the presented measures is based on the following criteria:

- Human-induced methane emission

- Represent one of the sectors considered to be a major source of methane emissions

- Actual implemented measure

- Technical measure, not financial or political instrument

- Measure that can be affected by technical solutions and not by human behaviour

- Case study with available information (published or verbal)

The methane abatement measures are categorized in relevant sectors identified by KoL and confirmed through a emission statistics from the Nordic countries. The six relevant sectors include Ruminant livestock, Manure management, Landfill, Waste water treatment, Waste management and the Oil and gas sector. The amount of emissions from each sector varies among the countries but the predominant sector in all the Nordic countries is agriculture, where both Ruminant livestock and Manure management are included. Norway is the only Nordic country where the Oil and gas sector is a significant contributor to methane emissions. 
Table 1 Measures presented in the catalogue

\begin{tabular}{|c|c|c|c|c|}
\hline Sector & Measure & $\begin{array}{l}\text { Plant/ } \\
\text { Location }\end{array}$ & Country & Why in the catalogue \\
\hline Ruminant livestock & $\begin{array}{l}\text { Production of milk } \\
\text { and meat with high } \\
\text { productivity combined } \\
\text { with high environmental } \\
\text { awareness. }\end{array}$ & Wapnö Farm & Sweden & $\begin{array}{l}\text { Wapnö is a good example } \\
\text { of that it is possible to } \\
\text { engage in a farm with high } \\
\text { environmental awareness, } \\
\text { animal consideration and } \\
\text { at the same time have } \\
\text { profitability. }\end{array}$ \\
\hline \multirow[t]{2}{*}{ Manure management } & $\begin{array}{l}\text { Large-scale biogas } \\
\text { production from manure, } \\
\text { organic waste and sewage } \\
\text { sludge for electricity and } \\
\text { heat production. }\end{array}$ & Måjberg Bioenergy & Denmark & $\begin{array}{l}\text { One of the largest biogas } \\
\text { plants in the world. Good } \\
\text { example of pipeline for } \\
\text { manure and digested sludge } \\
\text { distribution that reduces } \\
\text { the methane slip from } \\
\text { storage and transportation. }\end{array}$ \\
\hline & $\begin{array}{l}\text { Full-scale try-outs with } \\
\text { biogas production from } \\
\text { solid horse manure. }\end{array}$ & Sötåsen and JTI & Sweden & $\begin{array}{l}\text { The possibility to digest } \\
\text { manure from horses } \\
\text { will reduce the methane } \\
\text { emission from this sector. } \\
\text { Handling of horse manure } \\
\text { is in many areas a problem } \\
\text { today and the possibility } \\
\text { of digesting manure from } \\
\text { horses will reduce the } \\
\text { methane emissions from } \\
\text { this sector. }\end{array}$ \\
\hline \multirow[t]{3}{*}{ Landfill } & $\begin{array}{l}\text { Landfill gas collection } \\
\text { system and upgrading. }\end{array}$ & Álfsnes, SORPA & Iceland & $\begin{array}{l}\text { Good example of a } \\
\text { complete efficient system } \\
\text { for collection, upgrading } \\
\text { and use of gas from landfill } \\
\text { sites. }\end{array}$ \\
\hline & $\begin{array}{l}\text { Low- Tech biocover } \\
\text { system. }\end{array}$ & Klintholm losseplads & Denmark & $\begin{array}{l}\text { The technique is a cheaper } \\
\text { alternative to gas collection } \\
\text { system from landfills and } \\
\text { has shown high efficiency. }\end{array}$ \\
\hline & $\begin{array}{l}\text { Micro-meteorological } \\
\text { methods for efficient } \\
\text { recovery of landfill gas } \\
\text { and control of emissions. }\end{array}$ & $\begin{array}{l}\text { Päijät-Häme Waste } \\
\text { Disposal Ltd., Lathi }\end{array}$ & Finland & $\begin{array}{l}\text { The micrometeorological } \\
\text { method for landfill gas } \\
\text { control is a practical tool for } \\
\text { landfill design, operation } \\
\text { and control of emissions. } \\
\text { It has been possible to } \\
\text { develop improved gas } \\
\text { collection strategies, e.g., } \\
\text { increasing the number of } \\
\text { landfill gas recovery wells } \\
\text { and focussing their location } \\
\text { and operation on the basis } \\
\text { of data on emissions. }\end{array}$ \\
\hline
\end{tabular}




\begin{tabular}{|c|c|c|c|c|}
\hline Sector & Measure & $\begin{array}{l}\text { Plant/ } \\
\text { Location }\end{array}$ & Country & Why in the catalogue \\
\hline \multirow[t]{2}{*}{$\begin{array}{l}\text { Wastewater } \\
\text { treatment }\end{array}$} & $\begin{array}{l}\text { Increased biogas } \\
\text { production through } \\
\text { thermal hydrolysis of } \\
\text { sludge for digestion. }\end{array}$ & Fredericia Spildevand A/S & Denmark & $\begin{array}{l}\text { Good example of thermal } \\
\text { hydrolyses to increase } \\
\text { biogas production and } \\
\text { decrease methane } \\
\text { potential in the digested } \\
\text { sludge. }\end{array}$ \\
\hline & $\begin{array}{l}\text { Sealed tanks for digested } \\
\text { sludge. }\end{array}$ & Ryaverket, Gryaab & Sweden & $\begin{array}{l}\text { Good example of an } \\
\text { efficient action at an } \\
\text { existing WWTP. The } \\
\text { methane that previously } \\
\text { was leaking is now } \\
\text { captured and incorporated } \\
\text { into the biogas production. }\end{array}$ \\
\hline \multirow[t]{2}{*}{ Waste management } & $\begin{array}{l}\text { Pre-treatment and } \\
\text { anaerobic digestion of } \\
\text { organic waste. }\end{array}$ & $\begin{array}{l}\text { Uppsala Biogas Plant } \\
\text { Kungsängens gård, } \\
\text { Uppsala }\end{array}$ & Sweden & $\begin{array}{l}\text { Good example of one of the } \\
\text { first plants for anaerobic } \\
\text { digestion of organic } \\
\text { waste from households, } \\
\text { the entire process from } \\
\text { collection of waste to } \\
\text { production of biogas used } \\
\text { as vehicle fuel. }\end{array}$ \\
\hline & $\begin{array}{l}\text { Voluntary agreement for } \\
\text { biogas and upgrading } \\
\text { plants. }\end{array}$ & Several locations & Sweden & $\begin{array}{l}\text { A systematic approach } \\
\text { to quantification and } \\
\text { minimization of methane } \\
\text { emissions. To date } \\
\text { measurements and } \\
\text { calculations have been } \\
\text { performed at } 18 \text { individual } \\
\text { biogas plants and } 29 \\
\text { upgrading plants. }\end{array}$ \\
\hline Oil and gas & $\begin{array}{l}\text { Hydrocarbon blanketing to } \\
\text { eliminate VOC emissions. }\end{array}$ & & Norway & $\begin{array}{l}\text { HC blanketing systems } \\
\text { have successfully been } \\
\text { installed on a number of } \\
\text { Norwegian FPSOs and } \\
\text { have resulted in significant } \\
\text { avoided emissions of } \\
\text { methane and nmVOC from } \\
\text { crude oil storage. }\end{array}$ \\
\hline
\end{tabular}




\section{Background and aim}

\section{1 Background}

Within the scientific and policy communities there is growing recognition that efforts to address climate change should focus not only on reducing carbon dioxide emissions but also on near-term actions to reduce short-lived climate pollutants such as methane.

Though it is well known that carbon dioxide is the main force of anthropogenic global warming, scientists estimate that substances with shorter atmospheric lifetime account for 30 to $40 \%$ of the human-induced warming to date. Methane is one of these short lived climate pollutants, with an atmospheric lifetime of about 10 to 12 years. Reducing emissions of methane would result in important but shorter-term benefits. In addition, it is believed that reductions in methane emissions improve local air quality by reducing groundlevel ozone, which harms agriculture and human health.

Methane gas emissions are generated both from natural and human activity. A number of relevant sectors for anthropogenic methane emissions have been identified by The Nordic Climate and Air Pollution Group (KoL):

- Landfill

- Oil and gas systems

- Manure management

- Wastewater treatment

- Ruminant livestock

- Artificial wetland

The sector artificial wetland was initially identified by KoL but has since been reviewed and found irrelevant for the catalogue and therefore measures from this sector are not included here.

The Nordic Climate and Air Pollution Group (KoL) is a working group under the auspices of the Nordic Council of Ministers. The group decided recently to publish a catalogue of "Nordic initiatives to abate methane emissions" in order to spread the knowledge of best practice and efficient technical measures on how to abate methane emission.

As a part of the KoL initiative in January 2014, Ramböll received the assignment to compile this catalogue of "Nordic initiatives to abate methane emissions".

climate change should focus not only on reducing carbon dioxide emissions but also on near-term actions to reduce short-lived climate pollutants such as methane 


\subsection{Purpose and aim of the project}

The overall purpose of the catalogue is to disseminate information on effective methane reducing measures that can contribute to the further implementation of emission abatement measures by local authorities and businesses in the Nordic countries and in neighbouring countries.

The target group for the report is wide, ranging from policy makers, responsible for a top-level approach, to concerned plant and project owners accounting for emissions of methane e.g. municipalities, associations of local authorities, farmers, farmers associations, oil companies and agricultural authorities.

\subsection{Organisation}

The Ramböll organisation of the project included representatives from Ramböll Sweden, Denmark and Finland. The organisation consisted of a project management team that carried out the work, and a number of experts within Ramböll, who were consulted in specific matters.

Project management team

Cajsa Hellstedt - Project Manager

Jenny Cerruto - Assistant Project Manager

Maria Nilsson - Project Engineer

Ramböll experts

Michael McCann - Reviewer and expert gas techniques

Katarina Starberg - Expert biogas, wastewater treatment

Kai Sormunen - Expert waste and landfill

Will van Well - Expert gas process

Ligija Samuelsen - Expert landfill

Per Haugstedt Petersen - Expert landfill

Søren Knudsen -Environmental expert related to the petrol industry

\section{External experts}

An external group of representatives from each sector was formed. This group was given the opportunity to review both the interim report and the final report and had the opportunity to contribute with input regarding the selection of measures and other expert advice. The group consisted of representatives from:

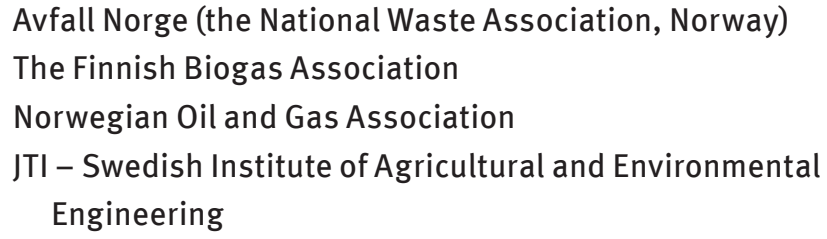


The Swedish Gas Association

Foreningen for Danske Biogasanlaeg (Association for Danish

Biogas Plants)

SLU Swedish University of Agricultural Science

The Federation of Swedish Farmers LRF

The work was also regularly communicated with the client, The Nordic Council of Ministers' Climate and Air Pollution Group (KoL), with Anna-Maria Gran as Coordinator.

\subsection{Method of work}

The implementation of the project was divided into four parts.

1. Screening and selection of relevant measures - interim report Information regarding the quantity of methane emissions from the different sectors in each Nordic country was collected and compiled. Selection criteria for the screening of relevant measures were defined and the screening carried out. A presentation of the screening was presented to $\mathrm{KoL}$ and to the external reference group in an interim report and discussed.

\section{Primary collection of information}

After feedback on the interim report from KoL and the external reference group, the selection criteria were formed as presented in chapter 1.5.1. and the final measures to be included in the catalogue were chosen to represent "good examples". Information about each measure was collected during interviews with representatives of the measures. In addition, information was gathered through published information and through discussions with a number of researchers and experts in each area.

3. Processing of data and calculations

The collected data was processed and calculations, mainly on methane emission and quantity of reduction, were carried out.

4. Compilation of the catalogue

The collected and processed information for each selected measure is presented in this catalogue. Based on the Nordic Council of Ministers guidelines and in dialogue with the graphic artist from the Nordic Council of Ministers, a draft of the catalogue was produced. The draft was reviewed by KoL after which a final version of the catalogue was completed. 


\subsubsection{Selection criteria}

These criteria have been used to select interesting methane abatement measures to be presented in this report.

Main selection criteria:

- Human induced methane emission

- Represent one of the identified relevant sectors of methane emission

- Actual implemented measure

- Technical measure, not economic or political instruments

- Measure that can be affected by techniques and not by human behaviour

- Case studies with available information (published or verbal)

The selection criteria above were defined and communicated with KoL-group through the interim report.

The main screening was performed using internal expertise at Ramböll in Sweden, Denmark, Norway and Finland together with external contacts in addition to internet references and published reports. The selection was performed mainly together with experts at Ramböll but also in dialogue with external experts to obtain each sector's assessment of good examples. 



\section{Methane emissions from different sectors}

This chapter is a general orientation of large and small methane emitting sectors and serves as background information to the selection of relevant sectors.

Statistics from national environmental agencies and national statistical bureaus in each Nordic country has been studied to obtain an overview of the methane emissions from different sectors. The level of detail and the categorisation differ somewhat among the countries but have been adjusted as far as possible to achieve comparability.

\subsection{Statistics and categorizing}

The total amount of methane emissions per year in the Nordic countries is in total about 900,000 tonnes of methane. The distribution is shown in Figure 1 below.

\section{Methane emissions, total in the Nordic countries}

Figure 1 Distribution of total methane emission in the Nordic countries

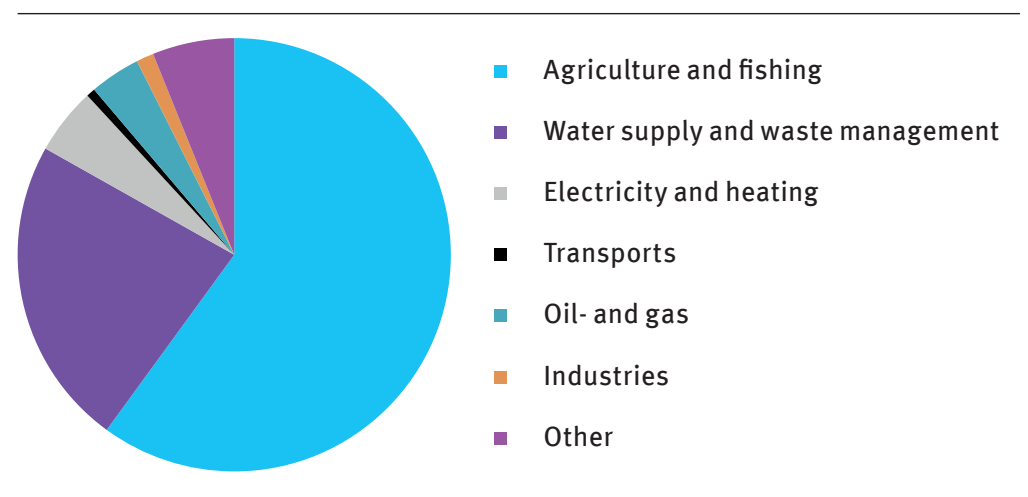

In all countries, the agricultural sector is the largest contributor, responsible for about $60 \%$ of the methane emissions. Waste management, including wastewater treatment, contributes with almost $25 \%$.

The following graphs in this chapter show the distribution within the main contributing sectors for each Nordic country. 
Figure 2 below shows the distribution of methane emissions in Sweden 2011 as published by the Swedish Environmental Protection Agency.

Methane emissions in Sweden 2011

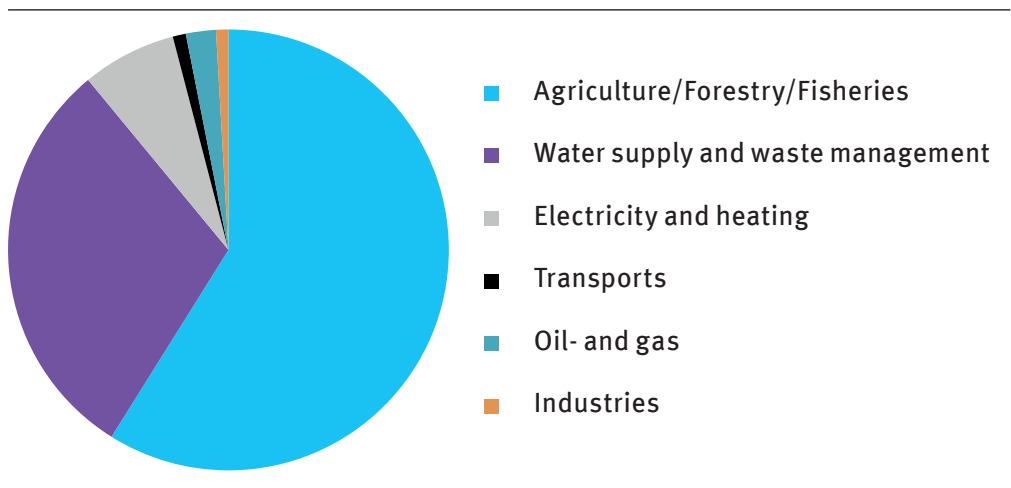

The total methane emissions during 2011 in Sweden amounted to 236,000 tonnes of which approximately $60 \%$ originated from the agricultural sector and about $30 \%$ from waste management (including wastewater treatment).

In Figure 3, methane emissions from different sectors in Norway during 2012 are presented. The data is published by Statistic Norway.

Methane emissions in Norway 2012

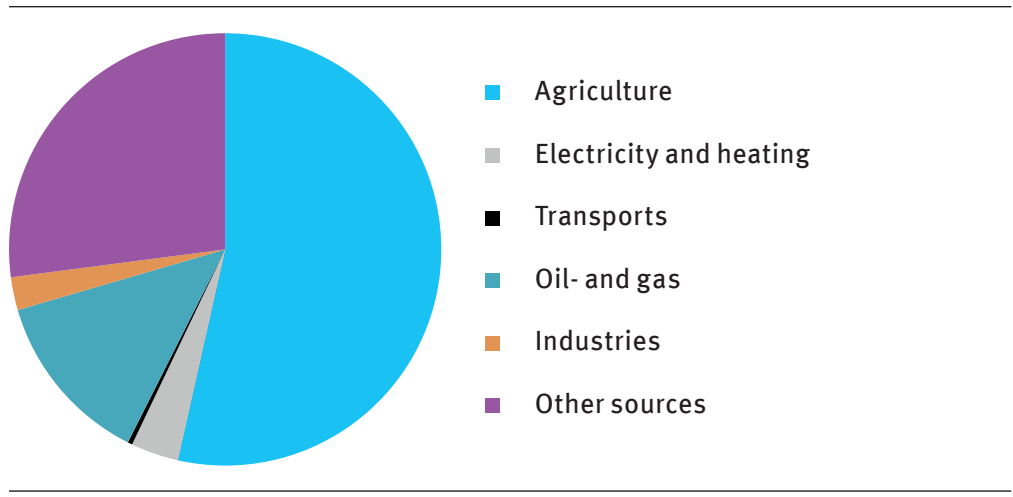

Figure 2 Distribution of main methane emissions in Sweden 2011. (Swedish Environmental Protection Agency, 2013)

Figure 3 Distribution of main methane emissions in Norway 2012 (Statistisk sentralbyrå, 2014)

The total methane emissions in Norway 2012 were 207,000 tonnes. The agricultural sector is responsible for more than $50 \%$ of the emissions and the oil- and gas sector about $10 \%$. In the Norwegian statistics, the waste sector (including wastewater treatment) contributes with about $30 \%$ of the total emissions. 
Figure 4 below shows the distribution of the Finnish methane emissions during 2011. The information is published by the Statistics Finland.

\section{Methane emissions in Finland 2011}

Figure 4 Distribution of main methane emissions in Finland 2011. (Statistics Finland, 2014)
Figure 5 Distribution of main methane emissions in Denmark 2011 (Statistics Denmark, 2014)

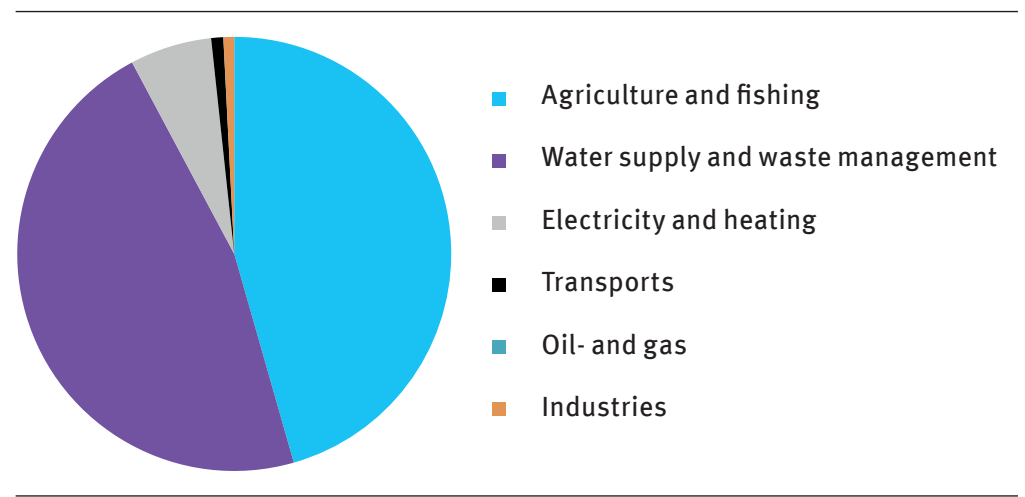

The total methane emissions in Finland were 200,000 tonnes in 2011. Agriculture and waste management each account for about $45 \%$ of the total emissions, thus together representing a total of approximately $90 \%$ from those two sectors.

The methane emissions from Denmark 2011 are shown in Figure 5 below. The data is published by Statistics Denmark.

\section{Methane emissions in Denmark 2011}

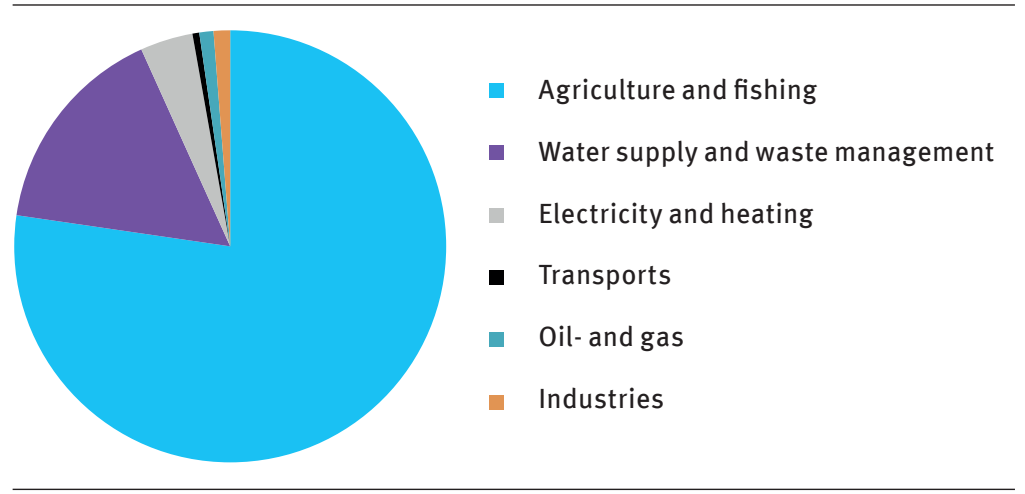

The total emissions of methane in Denmark 2011 was 257,000 tonnes, of which almost $80 \%$ (nearly 200,000 tonnes) originates from the agricultural sector and less than $20 \%$ from waste management. 
The methane emissions from Iceland 2011 are shown in Figure 6 below.

Methane emissions in Iceland 2011

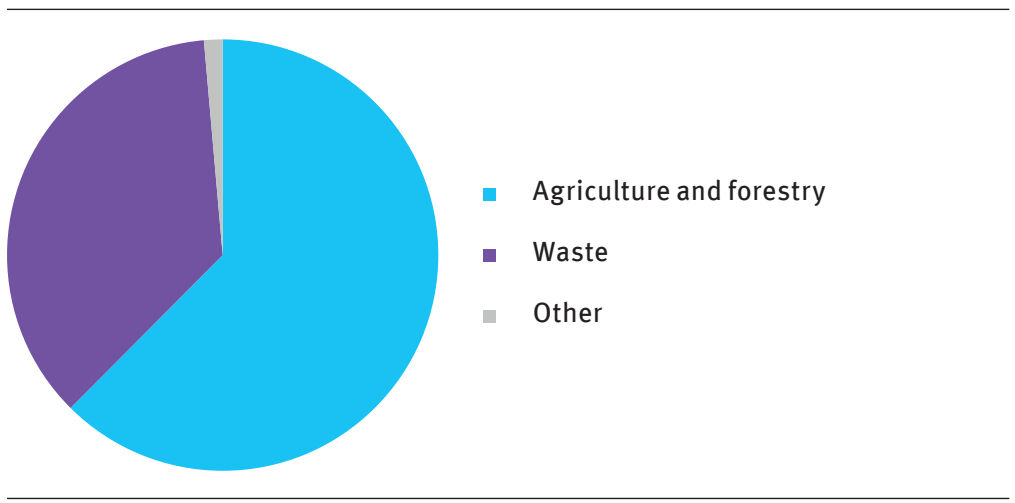

Figure 6 Distribution of main methane emissions in Iceland 2011. (Environment Agency of Iceland, 2013)

The total emissions of methane in Iceland 2011 were 24,000 tonnes of which more than $60 \%$ is from the agricultural sector and about $35 \%$ from waste management. The rest comes from other smaller sources.

\subsubsection{Summary statistics and categorizing}

The predominant sector for methane emissions in each Nordic country is agriculture. For some countries, the actual activities involved in this sector are not specified, but for example in Sweden, the agricultural sector is divided into subgroups (not shown in the figures above) and include enteric fermentation from livestock which contributes to almost $90 \%$ of the total methane emission from the agricultural sector. The other $10 \%$ is mainly from manure management.

The following list summarizes the range of methane emissions from each of the main sectors in the Nordic countries:

Agriculture $50-80 \%$ (average 60\%)

- Enteric fermentation $90 \%$ of emissions from the agriculture sector (approximately $40-50 \%$ of total methane emission in the Nordic countries)

- Manure management $10 \%$ of agriculture sector (approximately $5-10 \%$ of total the Nordic methane emissions)

Waste management (including waste water treatment) $20-50 \%$

(average 23\%)

- Landfill $80 \%$ of this sector (approximately $25 \%$ of total Nordic methane emission)

- Wastewater handling $20 \%$ of emissions (approximately $5-10 \%$ of total Nordic methane emission) 
Oil and gas $2-13 \%$ (average $4 \%$ ), large sector in Norway but not in the other countries

Electricity and heating 4-7\% (average 5\%)

- Main contributors are residential heating and electricity and heat production.

Based on the statistics from each of the countries relevant subsectors are stated as below:

- Ruminant livestock

- Manure management

- Landfill

- Waste water treatment

- Waste management

- Oil and gas (focus Norway only)

Measures of methane emission abatement are primarily investigated within these sectors.

\subsection{Description of each selected sector and sources of methane emissions}

Below, each selected sector is presented along with the initially identified measures from each sector. The finally selected measures are presented in chapter 4 .

\subsubsection{Ruminant livestock - enteric fermentation}

The agriculture sector contributes to the largest amount of methane gas emissions and represents between $50-80 \%$ of the Nordic countries total methane gas emissions. The vast majority of these emissions (90\%) come from enteric fermentation were cattle produce more methane emissions than other ruminants. Emissions associated with the production of animal forage are not taken into account.

Measures for abatement of methane emissions from ruminant enteric fermentation include:

- Reduce the number of ruminants (this includes increasing the productive life time of ruminants)

- Forage optimization - adjusting of the forage mix or use supplements effective to reduce the production of methane gas.

- Increase production efficiency - produce more output, e.g. milk or meet per digested amount of forage or used amount of energy.

- Genetics - breeding animals with lower methane gas emissions or use genetic manipulation to reduce the formation of methane gas during the food processing. 
Recently a report was published by the FAO (Food and Agriculture Organization of the United Nations) on technical solutions to mitigate emissions of Green House Gases (GHG), excluding carbon dioxide, from livestock. The techniques identified are listed in the Table 2.

\begin{tabular}{|c|c|c|}
\hline \multicolumn{3}{|c|}{ Mitigation practices to abate non- $\mathrm{CO}_{2}$ GHG emissions globally } \\
\hline \multirow[t]{16}{*}{ Enteric fermentation } & Feed supplements & Inhibitors \\
\hline & & Electron receptors \\
\hline & & Ionophores \\
\hline & & $\begin{array}{l}\text { Plant bioactive compounds } \\
\text { (PBAC) }\end{array}$ \\
\hline & & Dietary lipids \\
\hline & & Exogenous enzymes \\
\hline & & Direct-fed microbials \\
\hline & & Defaunation \\
\hline & & $\begin{array}{l}\text { Manipulation of rumen } \\
\text { archaea and bacteria }\end{array}$ \\
\hline & Feeds and feeding & Effect of feed intake \\
\hline & & Concentrate inclusion \\
\hline & & $\begin{array}{l}\text { Forage quality and } \\
\text { management }\end{array}$ \\
\hline & & Feed processing \\
\hline & & $\begin{array}{l}\text { Mixed rations and feeding } \\
\text { frequency }\end{array}$ \\
\hline & & $\begin{array}{l}\text { Precision feeding and feed } \\
\text { analyses }\end{array}$ \\
\hline & & $\begin{array}{l}\text { Mitigation options for } \\
\text { production systems based on } \\
\text { low-quality feeds }\end{array}$ \\
\hline \multirow[t]{4}{*}{ Animal husbandry } & $\begin{array}{l}\text { Enhancing animal } \\
\text { productivity }\end{array}$ & $\begin{array}{l}\text { Recombinant bovine } \\
\text { somatotropin (rbST) }\end{array}$ \\
\hline & & Animal genetics \\
\hline & & Animal health and mortality \\
\hline & Animal fertility & \\
\hline
\end{tabular}

Table 2 Overview of mitigation practices to abate methane (non CO2 GHG) emissions globally (Gerber et al. 2013 revised by Ramböll 2014).

Most measures are under development or practiced only as experimental measures. Very few of the measures to reduce methane gas emissions from ruminant livestock have been implemented in full scale (Bertilsson, 2014), (Lövendahl 2014), (Paulsson 2014), (Eksvärd 2014). In the European countries, usages of forage supplements are restricted and the legislation does not allow most of these substances to be used routinely in forage (Bertilsson 2014).

One of the few measures that actually has been implemented, with a natural economic incentive for the farmer, is to increase productivity. The selected case study described in this report is a farm with a high productivity and a documented high level of environmental awareness. No cases with the specific purpose of reducing methane gas emissions have been found. The reduction in emissions has nevertheless been a significant and positive side effect of efficient farming. 


\subsubsection{Manure management}

Manure management is a large contributor to methane emissions in the agricultural sector. Anaerobic digestion of manure, followed by utilization of biogas for the production of electricity and heating and/ or upgrading to vehicle fuel, is the main methane abatement measure.

The measures presented in this report are an assortment of biogas plants representing different plant sizes, digesting of different kinds of manure as well as different techniques for handling the gas implemented in the Nordic countries. Four different plants are presented in chapter 4 as good examples:

- Large-scale biogas production at Måjberg Bioenergy, Denmark

- Small-scale biogas production at Lövsta, Sweden

- Full-scale tests with digestion of solid horse manure at Sötåsen, Sweden

- Small-scale local biogas production with gas distribution pipelines to a common upgrading plant at Biogas Brålanda, Sweden

The digestion of manure is here assumed to mainly contribute to the reduction of methane emissions by replacing energy from fossil sources with biogas.

It has been a common idea that digesting manure would reduce the amount of methane released from the manure when stored and used as fertilizer compared to non-digested manure. Recently, some new studies have compared the greenhouse gas emissions from digested and non-digested manure (Rodhe et. al., 2013). These studies show a large variation between the level of emissions in summer and winter and states that the methane emission from non-digested manure is lower than from digested manure in the summer but the other way around during winter. In both cases the methane emissions were much higher during summer than during winter, as expected.

To be able to reduce the methane emission from digested manure it is important to ensure proper digestion, e.g. long digestion time with post-digestion and/or collecting gases in gas-tight storage.
Methane emission from manure is thus very dependent of how the manure is stored, cooled and how far-reaching the anaerobic degradation of organic content in manure is. However, it is indisputable that manure digested in a biogas plant has a lower content of organic matter and thus a lower methane gas potential.

The conclusion from the study and from discussions with scientists is that it is not possible to quantify a general standard emission value to calculate the change in methane emission when digesting manure. To be able to reduce the methane emission from digested manure it is important to ensure proper digestion, e.g. long digestion time with post-digestion and/or collecting gases in gas-tight storage. 


\subsubsection{Landfill}

In the Nordic countries, with the exception of Iceland, where reliable data have not been found, methane emissions from landfills contribute to approximately $25 \%$ of the total methane emissions based on background data to the statistics presented in figures $2-5$. This makes emissions from landfills the second largest source of methane emissions, after the agricultural sector.

Landfill depositing of organic waste is prohibited in all the Nordic countries. Methane emissions from this sector will therefore slowly decrease over the years as the remaining organic content in the landfills decomposes and methane gas is formed. Over time the organic content will be too low and methane emissions will naturally cease without any further actions. Nevertheless, landfills contribute to large contemporary methane emissions and there is a need to implement methane reduction measures for landfills. Table 3 below shows the number of landfill sites with biogas recovery systems in the Nordic countries (except Iceland) today.

\begin{tabular}{lcc}
\hline & Number of sites & $\begin{array}{c}\text { Biogas production, raw biogas } \\
\text { (GWh/year) }\end{array}$ \\
\hline Denmark & 30 & 83 \\
Finland & 39 & 312 \\
Norway & 85 & 270 \\
Sweden & 55 & 254 \\
\hline
\end{tabular}

Table 3 Number of Landfill sites with biogas recovery systems (IEA BIOENERGY, 2014)

Four different measures for methane abatement measures from landfills have been selected as good practice. These are as follows (see also chapter 4):

- Landfill gas collection and upgrading at Álfsnes, Iceland

- Low-tech biocover system at Klintholm losseplads, Denmark

- Micrometerological methods for efficient recovery of landfill gas and control of emissions at Päijät-Häme Waste Disposal Ltd., Finland

- Using landfill gas with low methane content to a further extent with an stirling engine

\subsubsection{Waste water treatment}

Methane emissions from wastewater treatment plants originate mainly from sludge handling. The issue with greenhouse gas emissions from wastewater treatment plants has come into focus recently and there are currently several ongoing projects to measure methane emissions from different parts of the plants. 
Table 4 Number of waste water treatment plants with biogas production (IEA BIOENERGY, 2014)
Digestion of sludge and upgrading plants is the most efficient way to collect the produced methane from waste water treatment. Table 4 shows statistics of wastewater treatment plants in the Nordic countries with biogas production (except Iceland).

\begin{tabular}{lcc}
\hline & Number of sites & $\begin{array}{c}\text { Biogas production, raw biogas } \\
\text { (GWh/year) }\end{array}$ \\
\hline Denmark & 65 & 220 \\
Finland & 15 & 135 \\
Norway & 25 & $164^{*}$ \\
Sweden & 135 & 660 \\
\hline 2008 & &
\end{tabular}

Digestion of sludge is currently a very well implemented technique in the Nordic countries but there are ways to optimize the biogas production and to reduce the leakage of methane from the digested sludge. One implemented measure for more efficient digestion and reduction of methane leakage of methane from digested sludge has been selected and one measure for reducing methane leakage from storing of digested sludge. These two measures are presented in chapter 4:

- Thermal hydrolysis of sludge for digestion at Fredericia WWTP, Denmark

- Sealed storage tanks for digested sludge at Ryaverket WWTP, Sweden

\subsubsection{Waste management}

Handling of organic waste is a large contributor to methane emissions. In the past organic waste has been deposited at landfills. These methane emissions were addressed in chapter 2.2.3. Currently most organic waste, in the Nordic countries, is treated in waste fired combustion systems, via anaerobic digestion or compost handling.

Combustion of organic waste completely eliminates methane emissions. Although anaerobic digestion of organic waste can lead to small levels of methane emissions the gas can play an important role in replacing fossil fuels as an energy source. Thus anaerobic digestion of organic waste may be considered a powerful measure for methane abatement. Many countries have a goal to reduce the combustion of organic waste and instead digest or compost the organic waste fractions. The main reason is to recycle nutrients to farming. Anaerobic digestion is one of the few ways to both recover the energy content and recycle nutrients to the agricultural production systems. 
Two measures have been selected and are presented further in chapter 4:

- A system of pre-treatment, anaerobic digestion and upgrading of gas at Uppsala Biogas, Sweden

- The Swedish voluntary agreement for AD and upgrading plants at 18 individual biogas plants and 29 upgrading plants, Sweden

\subsubsection{Oil and gas systems}

Seen in a global context the oil and gas sector represent more than $20 \%$ of the world's anthropogenic methane emissions. Within the Nordic countries Norway is the only country where the oil and gas sector is a significant emitter of methane gas. According to the Norwegian Oil and Gas Association (2013) the largest sources of methane emissions within the oil and gas sector are cold venting and fugitive emissions from flanges, valves and various processing equipment.

The same source states that the total emissions of methane from the offshore oil and gas sector in Norway in 2012 were approximately 25,600 tonnes. Distributed on sources $71 \%$ was reported amounts of methane from both diffuse emissions and cold venting, $11 \%$ was from loading, $1 \%$ was from storing and finally $16 \%$ was emissions from other sources. Emissions from other sources are derived mainly from fugitive emissions (also cold venting) when burning gas in flare, motor or boiler and when exploring oil and testing the quality of wells. Traditionally methane emissions from loading have been significant but over the years these emissions have gone down (Norwegian Oil and Gas Association 2013).

Diffuse emissions are difficult to measure and are dependent on many factors. Reported amounts of methane from both diffuse emissions and cold venting are to a large extent based on standard emission factors related to equipment or produced volumes (mostly on standard emission factors from the Norwegian Oil and Gas Association).

The methane emissions from cold venting and diffuse emissions are also aggregated in environmental reports. Therefore, there are uncertainties both in actual emission volumes and how the share of diffuse emissions and cold venting respectively allocates (Norwegian Environment Agency 2013).

A detailed study on methane emissions from the oil and gas offshore industry is planned for 2014 and 2015, i.e. gas venting and fugitive emissions (Sissel Sandgrind on the Norwegian Environment Agency 2014). This study will, among others, focus on the following elements: 
- Improvements of monitoring and calculation methods

- Emission reduction techniques (BEP and BAT)

- Evaluation of further mitigation options

- Maintenance strategies and leak detection programs

The results from this study will most certainly contribute to the further implementation of best practice (BEP) to abate emission of methane and also to the continuous development of best available technique (BAT). Already today several techniques to abate emissions of methane are implemented in Norway. In the report Best practices for reduction of methane and black carbon from arctic oil and gas production (2012), Carbon Limits has described several abatement measures considered to be best practice today. Some of the best practices with a potentially high emission-reducing effect are listed below.

\section{Cold Venting}

- Flare instead of vent

- Utilization of the gas (recycling the gas back to the low pressure part of the processes or to the fuel gas system)

\section{Fugitive emissions}

- Directed Inspection and Maintenance

- Subsea leakages detection and repair

\section{Storage and loading of hydrocarbon products}

- Reduce operating pressure upstream

- Increase tank pressure

- Change geometry of loading and pipes

- Vapor Recovery Unit - Gas compression

- Vapor Recovery Unit - Ejector

- Vapor Recovery Unit - VOC condensation \& gas recovery

In chapter 4 a selected case study concerning VOC emissions (volatile organic compounds both methane and other VOC) from cargo tanks is presented in more detail. 



\section{Conditions and criteria for calculations}

This chapter presents an overview of the methane reduction calculation for each measure.

The level of detail involved in each of the calculations varies greatly due to the fact that varying levels of data were available for each case.

Data has been collected according to the following priority order (were the first indicates the highest level of detail and accuracy of case specific conditions):

- Actual measured emission values from the plant owner or project owner. No standard emission values were needed in this case.

- Using case specific facts such as power and heat production, fuel production and amount of energy replaced combined with standard emission values to calculate actual emissions.

- Assumed conditions of how much energy is produced and what energy is replaced in combination with standard emission values.

Implicit system boundaries were defined when using standard emission values in order to fit better with the specific case.

It is important that the methane emission values, and cost efficiencies presented in this report are not compared between different case studies without specific regard to the varied conditions under which these values have been developed.

\subsection{System boundaries and conditions}

To perform the calculations, system boundaries were defined for each measure. In order enable calculations to be carried out, a number of assumptions were made in each case and these assumptions, based on known facts as much as possible, are presented in the description of each case in chapter 4. One particular challenge was due to the fact that the level of detail varied widely between the different measurements. This complicates further any attempt to compare methane reduction values between the different measures.

\subsection{Cost effectiveness}

In many of the calculations, standard emission values for calculations of methane reductions are taken from the Environmental fact report (Miljöfaktaboken 2011, uppskattade emissionsfaktorer för bränslen, el, värme och transporter. Värmeforsk). This report compiles standard emission values for most fuels, power production, heat and transport. 
When electricity is produced from biogas instead of from fossil fuel the standard value for methane emission of Nordic power production is used in the calculations of emission reduction (see list below). Production of heat from biogas is often used to heat the digestion process and this heat is not included in the net emission reduction. The surplus of heat produced is however replacing usage of heat from other sources and emission change is thus calculated using standard emission values accordingly. The case specific assumptions on which heat replaced in each case study is specified in each case description in chapter 4. When the biogas is upgraded to vehicle fuel it is assumed biogas replaces diesel for busses since this is a common fact in many cases.

The key factors for emissions used are:

Combustion of wood chips, small scale
Efficiency of bio boiler
Nordic power mix
Production and utilisation of diesel, busses
Natural gas

$0.0017 \mathrm{~g} \mathrm{CH}_{4} / \mathrm{MJ}^{1}$

$80 \%{ }^{2}$

$0.11 \mathrm{~g} \mathrm{CH}_{4} / \mathrm{kWh}^{3}$

$0.034 \mathrm{~g} / \mathrm{MJ}^{4}$

$0.275 \mathrm{~g} \mathrm{CH}_{4} / \mathrm{MJ}^{5}$

In order to present cost effectiveness in terms of investment cost as a function of amount of methane reduced, investment costs are annualised using a payback time of 20 years and annual interest of $7 \%$.

The value of recovered gas is not included in calculating the costeffectiveness of methane mitigation methods presented in this report.

Regarding digestion of manure, it should be noted that IPCC recommends a methane conversion factor (MCF) for stored liquid manure of $10 \%$. It is unlikely that this values reflects methane emissions from stored liquid manure in the Nordic countries however, in the absence of concrete suggestions for MCF applicable to Nordic climate, a value of $10 \%$ was used (see further explanation section 2.2.2).

\section{In order to present cost effectiveness in terms of investment cost as a function of amount of methane reduced, investment costs are annualised using a payback time of 20 years and annual interest of $7 \%$.}

1 Gode et al. 2011, 32.
2 Gode et al. 2011, 32.
3 Gode et al. 2011, 126
4 Gode et al. 2011, 85.
5 Gode et.al. 2011, 60. 




\section{The Catalogue}

This chapter presents 14 different god examples of measures to abate methane emissions. Each measure is presented with available information regarding

- technical description

- methane reduction and other benefits

- costs

- barriers and difficulties

- contact information for each case study

The catalogue should be read as an initial guide for the selected technical measures. For more detailed description please refer to the contact person for each example.

Conditions and criteria for calculations are described in chapter 3. Calculations of methane emission reduction and cost estimation are based on available information and implemented where possible. In some cases it has not been possible to establish relevant system boundaries for the technical measure and the cost estimation is thus missing. For example it is difficult to estimate an investment cost for changing the diet in dairy production since the change in cost is split between several different cost carriers, and the allocation is not obvious. Also, lack of measurements or information has made it difficult to quantify the methane emission reduction effect for some methane reduction measures all though there is a confirmed and recognized methane reduction effect. As far as possible this challenges are described under each presented measure. When it has been considered reasonable to make assumptions without risking to describe the case study misleadingly (and when possible within the budget) default values, system boundaries and general investment costs are presented when case specific facts are missing.

Early in the project the quantification of emissions reduction and cost were identified as important information but also pointed out as consuming figures to quantify fairly. It has not been included in this project to analyse the data that have emerged during the compilation of the catalogue but the author has summarized some observations in chapter 5 Authors comment.

All figures presented in this chapter have been approved for publication by concerned plant and project owners. 


\subsection{Production of milk and meat with high productivity combined with high environmental awareness.}

Plant: Wapnö Farm

Location: Halmstad, Sweden.

Start-up year: The estate has been in use since the early fourteenth century. A part of Wapnö farm, 700 ha, was certified by KRAV (Swedish organic standard) 1995. It was converted to a limited company in the early 2000 s.

\section{Technical description}

Wapnö farm holds about 1,350 dairy cows and 2,000 calves and heifers for replacement meat production. Through a strategic breeding the dairy cows produce milk with a high protein content and also meat of comparatively good quality. This is possible by crossing typical milk breeds (the two breeds used at Wapnö are Holstein and SRB) with dual purpose breed f.eg. Simmental. As a health and safety measure to reduce the risk of udder inflammation a cow with high positioned udder (the milk breed Holstein) is interbred with the Wapnö cow. All of the dairy cows are inseminated with sexed semen, $50 \%$ of dairy purposes and 50\% with the beef breed Limousin.

The milk cows are productive for over three years and produce about $30 \mathrm{~kg}$ of milk per day $(9,500-10,500$ per year). The protein content is high in the milk and the meat quality is slightly better so this is a profitable concept according to the farmer. The heifers with Limousine father are used for beef production only. They reach full growth at about 20 months of age witch can be compared to 12-13 months when using bulls with pure beef breed. The heifers are held on pasture a large part of the year which in fact is considered to increase methane emissions (FAO 2013a). During winter and when pasture is not enough and the animals are feed with a mix of grass silage whole-crop cereal silage and grain. This diet is on the other hand considered to lower the methane emissions from enteric fermentation in ruminant (FAO 2013a). The addition value of having grazing heifers at Wapnö is they keep the landscape open and contribute to the biodiversity by doing so. This concept of combining beef and milk production at the same time as biodiversity is benefited is marketed as environmental meat.

The forage at Wapnö is Härodlat ${ }^{\circledR}$ which means it is produced at the own farm. This increases the farmers possibility to produce an optimally forage composition for the own animals. About $70-80 \%$ of the areal is cultivated with grass and the rest is, pasture, cereal that also gives straw for bedding. Wapnö is aware that pasture-finished cattle

\section{Short facts}

Wapnö Farm is a combined producer of milk and meat with a high environmental awareness. From the animals they have they produce

- protein rich milk,

- meat of goof quality from dairy cows and heifers

- plus biogas through anaerobic digestion of the manure

Providing as much output from one animal as possible is a good way of minimizing the emissions of methane per produced output. Wapnö also have a high awareness of the forage quality and its contribution to high productivity and minimized methane emissions. In order to maintain a high productivity and environmental care Wapnö have decided to produce the forage on their own farm, combining organic standards with conventional farming. They call it unconventional farming. Plus they try to have an energy efficient machinery to minimize usage of fossil fuel.

Why a methane abatement measure: Wapnö is a good example it is possible to integrate high environmental awareness, animal 


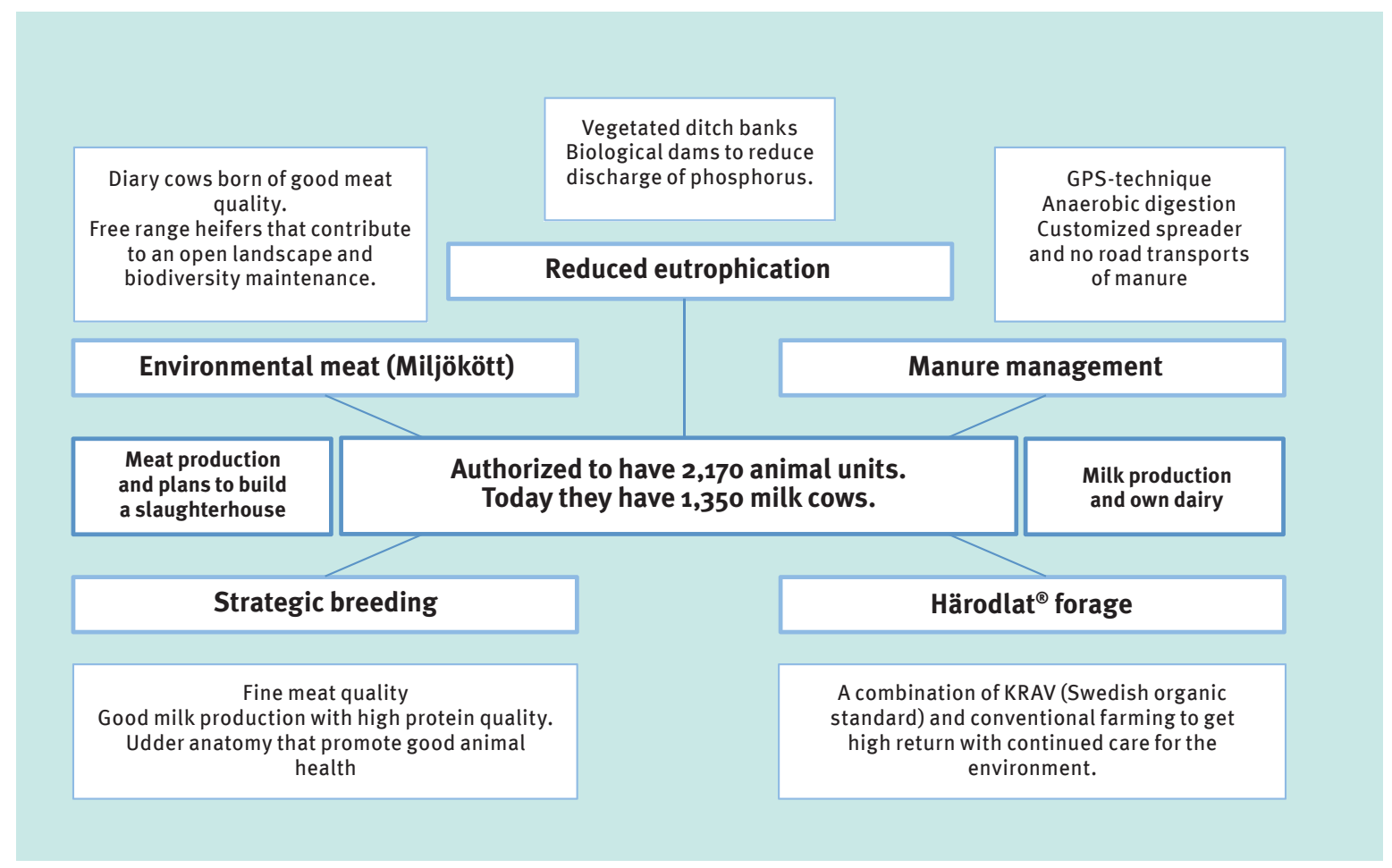

Figure 7 Overview of the animal husbandry at Wapnö farm.

consideration and at the same time have profitability in a farming company.

\section{Calculated yearly methane} reduction: Methane emissions from ruminant livestock are still researched and specific reduction at Wapnö will not be quantified due to lack of information. Scientists agree, however, high productivity without compromising animal health and environmental aspects is one possible sustainable way to reach lower methane emissions per produced unit. increase the methane emissions. At the same time it's important for Wapnö, from an ethical perspective, to provide conditions for the animals to behave naturally and be prosperous, this includes letting theme graze in summer. Wapnö's high animal welfare results in healthy animals with less need for antibiotic which means reduced risk for antibiotics resistance.

The farm has a long experience from farming according to Swedish organic standard (KRAV) where one demand is (if possible) to use the farms own manure as fertilizer to close the nutrients cycle. Furthermore the farm has adjusted their routines in the stables to minimize water usage and dilution of the manure. Besides there will be less manure volumes to handle, this is also advantageous for the farms biogas production plant. After the anaerobic digestion the farm is provided with a relatively odorless excellent biofertilizer. To minimize transports on road the biofertilizer is pumped in permanent pipelines to satellite basins near the fields where it is to be spread. All machinery is energy efficient to minimize usage of fossil fuels. The latest investment is a new manure spreader that pumps the biofertilizer from the basin instead of carrying a heavy loaded manure tank on the machine and risk soil compaction. Lighter load on the spreader makes it possible to begin spring tillage earlier and minimization of soil compaction also makes the soils conditions more favorable for higher yields. The farm is also taking steps to reduce nutrient losses and eutrophication. 


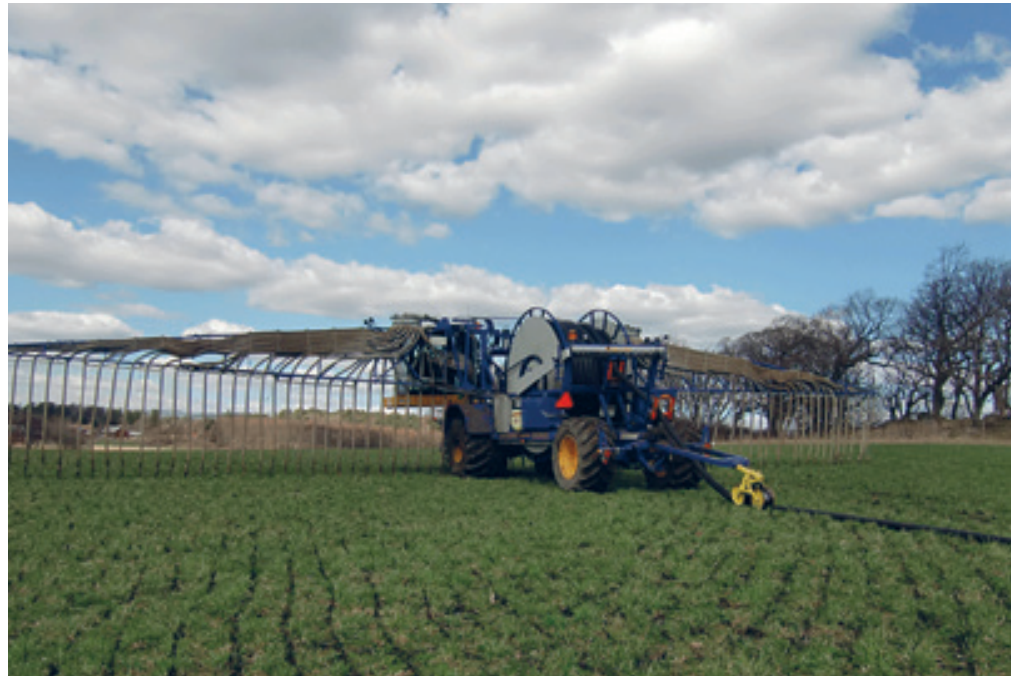

\section{Methane reductions and other benefits}

No action taken at Wapnö farm has been implemented with the explicit goal to minimize methane emissions. However the farm is very aware of environmental aspects and they have knowledge about some factors that affect methane emissions for example the cattle diet composition.

Any accurate calculations of the methane emission reduction have not been possible to make within this study due to lack of data. Some factors also have opposite effect on emissions f.eg. forage with a mix of grass silage, whole-crop cereal silages and grain during winter and pasture during summer, which complicates assessment. To get an accurate reduction amount emission measurements have to be done and a model would need to be set up. There is however some guiding results from other studies.

In general western European farmers already have a relatively low amount of methane emissions per produced unit especially compared to farmers in developing countries (FAO 2013b). According to a study by FAO (2013b) dairy production in OECD ${ }^{6}$ countries could however still reduce GHG-emissions by $14-17 \%$ compared to baseline emissions with feasible improvements in manure management, energy efficiency, feed quality and animal performance. A qualified estimation, discussing with scientists in both Sweden and Denmark, is that an adjusted diet could reduce methane emissions with about $10 \%$ compared to baseline emissions.

How much methane the cows at Wapnö emits has not been measured but down below an calculation example is made based on emission data from The Swedish Institute for food and biotechnology (Cederberg et. al. 2009) and the assumption that $10 \%$ of methane emissions can be reduced at Wapnö thanks to adjusted forage composition.
Figure 8 Manure spreader with tubing to manure concrete storage.
6 Includes Austria, Belgium, the Czech Republic, Denmark, Estonia, Finland, France, Germany, Greece, Hungary, Ireland, Italy, Luxembourg, the Netherlands, Poland, Portugal, Slovakia, Spain, Sweden, the United Kingdom of Great Britain and Northern Ireland, Switzerland, Norway, Iceland, Chile, Mexico, Israel, Turkey, Japan, Republic of Korea, Australia, New Zealand, Canada and the United States of America. 
Table 5 Example of methane reduction using standard values and estimated reduction potential.

\section{Contact information}

Lennart E. Bengtsson

CEO Wapnö Farm

+46 (0)35-2990301

lennart@wapno.se

\begin{tabular}{|c|c|c|c|}
\hline & Milk cow & Hifer & Total \\
\hline $\begin{array}{l}\text { Standard emission values } \\
\left(\mathrm{kgCH}_{4} / \mathrm{hd} \mathrm{yr}\right)\end{array}$ & 135 & 53 & \\
\hline Animals at Wapnö & 1,350 & 2,000 & 3,350 \\
\hline $\begin{array}{l}\text { Yearly standard emissions } \\
\left(\mathrm{kgCH}_{4} / \mathrm{yr}\right)\end{array}$ & 182,250 & 106,000 & 288,250 \\
\hline $\begin{array}{l}\text { Assumed reduction } \\
\text { compared to baseline (10\%) }\end{array}$ & $10 \%$ & $10 \%$ & $10 \%$ \\
\hline $\begin{array}{l}\text { Yearly calculated emission } \\
\text { reduction }\left(\mathrm{kgCH}_{4} / \mathrm{yr}\right)\end{array}$ & 18,225 & 10,600 & 28,825 \\
\hline
\end{tabular}

In addition to this reduction Wapnö should also have reduction of emissions thanks to a more energy efficient machinery, the biogas production and the efficient manure management with less transport on the roads.

\section{Costs}

Total cost for the breeding program, the cultivation methods, the forage production, manure management system and biogas production has not been estimated. However Wapnö writes the following statement regarding their energy investment (the biogas plant).

Energy investments have a too long Pay Back time but in the longer term Wapnö sees the investment as superior both regarding climate and energy and it provides a possibility for the costumers to climate compensate locally.

In FAO (2013b) the following statement is found

In the absence of financial incentives (e.g. mitigation subsidies) or regulations to limit emissions, most producers are unlikely to invest in mitigation practices unless they increase profits or provide other production benefits such as risk reduction.

This suggests many measures are too expensive for the individual farmer although it lies in the interest of society and the farmer to reduce methane emissions.

\section{Barriers and difficulties}

Two identified and clear obstacles are

- Many emission reduction measures in the ruminant livestock sector are still researched and lack of knowledge is still to be considered a barrier.

- The absence of financial incentives and regulation is problematic and a barrier to the implementation of existing measures in farming business. 


\subsection{Large scale biogas production from manure, organic waste and sewage sludge for electricity and heat production}

Plant: Måbjerg BioEnergy

Location: Holstebro (Måbjerg), Denmark

Start-up year: 2012

\section{Technical description}

The slurry is transported to the plant by a combination of pipelines and road transport, though mainly by road ( 50 truckloads per day). Originally, a network of pipelines in a "star formation" were planned, but after reconsidering cost and benefit only one slurry hub was constructed, $16 \mathrm{~km}$ east of town.

The pipeline is made up of two separate lines. One for pumping slurry into the facility as raw material for the biogas process and one for returning digested sludge.

A similar pipeline (approximately $4 \mathrm{~km}$ ) connects the Holstebro sewage plant with the Måbjerg BioEnergy plant.

The material in to the plant is presented in Table 6:

\begin{tabular}{lc}
\hline Biomass input & Tonnes/year \\
\hline Liquid and solid animal waste & 450,000 \\
Food industry waste & 270,000 \\
Waste water from local sewage facility & 80,000 \\
\hline Total & 800,000 \\
\hline
\end{tabular}

\section{Short facts}

One of the largest biogas plants in the world. The plant is owned by two local utilities ( $2 / 3$ owned by Vestforsyning, Holstebro, and $1 / 3$ owned by Struer Forsyning). It is run in close cooperation with the suppliers association, a cooperative of farmers and a group of companies within the waste- and energy sector.

A schematic view over the system is presented in figure 9.

The plant is expected to produce at least 18 million $\mathrm{Nm}^{3}$ biogas per year. In 2014 expected output is $20-21$ million $\mathrm{Nm}^{3}$. Some of the gas is used for the own process $\left(7\right.$ million $\mathrm{Nm}^{3}$ ) and the rest of the gas is distributed through a pipeline to the Vinderup heating plant (7.2 million $\mathrm{Nm}^{3}$ ) and Måbjerg (3.5 million $\mathrm{Nm}^{3}$ ) central heating plant for production of heat and power.

Måbjerg BioEnergy will meet the demand for heating in 5,000 homes and supply 12,000-12,500 homes with power. Besides biogas Måbjerg BioEnergy will produce 40,000 tonnes of fiber from animal waste to be combusted at the Måbjergværket central heating plant. 


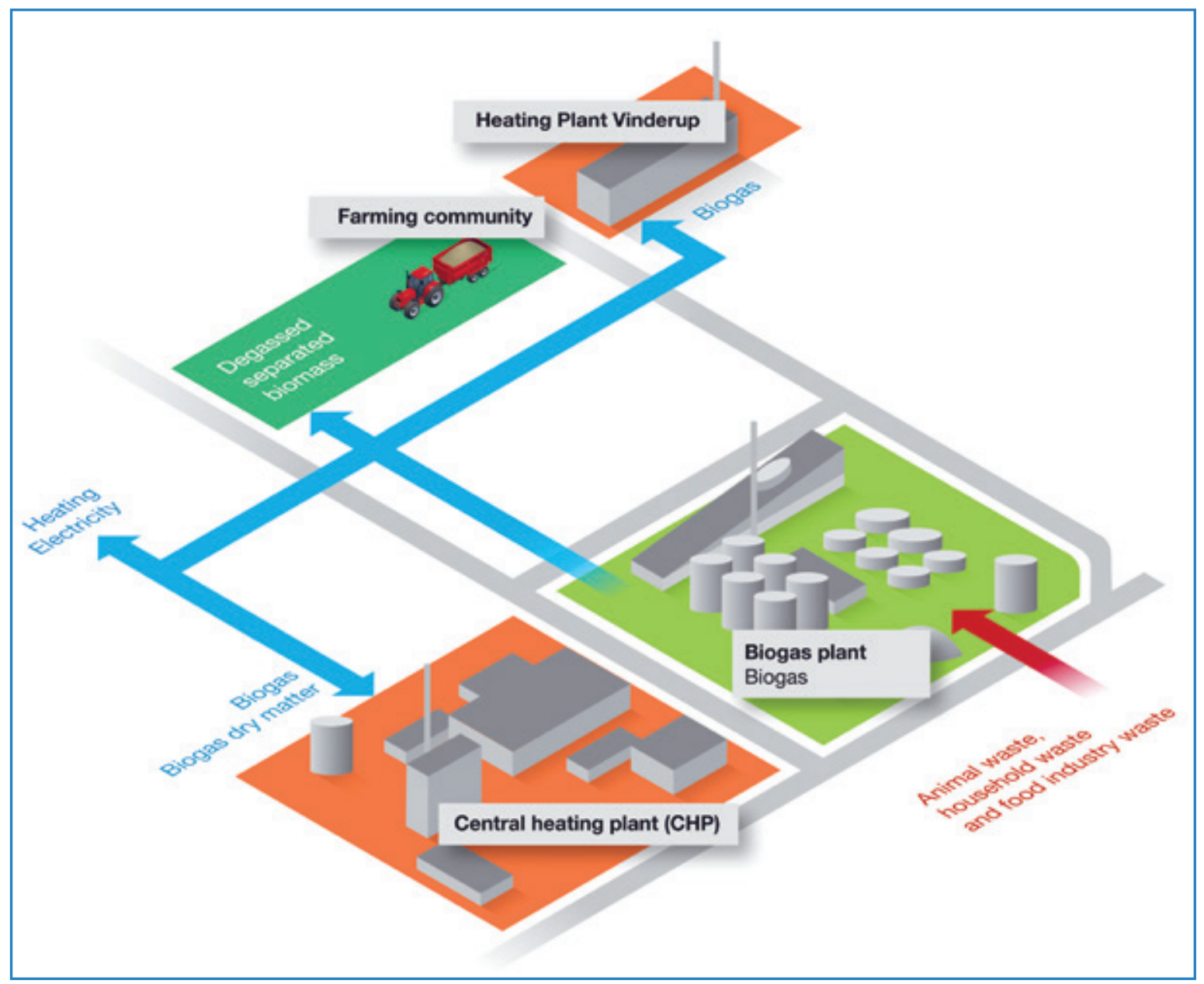

Figure 9 Overview of the process

\section{Methane reductions and other benefits}

The methane reduction from the plant is mainly due to two factors:

- Replacement of electricity and heat produced from fossil sources

- Reduction of diffuse small methane emissions by distributing by pipeline

\section{Replacement of electricity and heat}

The total amount of reduced methane from replacement of electricity and heat from fossil fuels is approximated to about 63 tonnes $\mathrm{CH}_{4}$ per year. The calculations are based on emission factors adjusted to known facts and assumptions about the plant. The gas at the heating site is assumed to be replacing heat production from natural gas and the electricity produced is assumed to be replacing Nordic power mix. The key factors for emissions used are: 


\section{Natural gas \\ $0.275 \mathrm{~g} \mathrm{CH}_{4} / \mathrm{MJ}^{7}$ \\ Nordic power mix \\ $0.11 \mathrm{~g} \mathrm{CH}_{4} / \mathrm{kWh}^{8}$}

The plant produces about 49.1 GWh electricity each year of which is assumed to replace the use of electricity from the national grid as mentioned previously. This equates to a reduction of about 5.4 tonnes $\mathrm{CH}_{4}$ per year. About $58.2 \mathrm{GWh}$ heat is produced from gas from the plant which is assumed to replace natural gas and with the emission factors described above the reduction of methane is calculated to about 57.6 tonnes per year.

\section{Other benefits}

The plant contributes to maintaining a cycle of nutrients. Some of the nutrients in the manure become available for the plants compared to not digested manure, mainly because of the lower viscosity of degassed slurry. The nutrients in the industrial waste will also be returned to agricultural use and can thus replace other fertilizers.

According to Mjaaberg Bioenergy the process yields two socioeconomic benefits. Energy production reduces costs and the farming community is able to maintain current production level while polluting less. Over 20 years the socioeconomic benefits is estimated at DKK 1 billion (about 134 million Euro).

\section{Costs}

The total investment for the plant is about 58 million Euro distributed as shown below.

\begin{tabular}{lcc}
\hline & M DKK & M Euro \\
\hline Bio energy facility & 329 & 44 \\
Pipelines, slurry transport & 65 & 8.7 \\
Misc. & 43 & 5,7 \\
\hline Total & 437 & 58.4 \\
\hline EU funding & 25 & 3.4 \\
\hline Net investment & 412 & 55 \\
\hline
\end{tabular}

Annualised costs were calculated to be 5,190,000 $€ /$ yr. No information was provided and thus it was not possible to incorporate running costs into the annual cost.

Based on the assumptions presented in section 3, and figures in 4.2, the cost effectiveness of the Maabjerg plant, as a means to reducing methane emissions, is 5,217 €/ton $\mathrm{CH} 4$.

\section{Short facts}

The plant co-digests manure, organic waste from food processing industries and sewage sludge. The plant receives manure slurry from more than 140 suppliers. Each manure supplier receives in return an amount of digested sludge equivalent to the livestock manure supplied. Some of the slurry is distributed through a pipeline (about $16 \mathrm{~km}$ ) made up of two separate lines, one for pumping slurry into the plant and one for returning the digested sludge.

The plant produces 18 million $\mathrm{Nm}^{3}$ biogas per year and the majority of the biogas produced is transported via a $16 \mathrm{~km}$ low pressure pipe line to Vinderup heating plant.

Table 7 Investment costs for the plant

\footnotetext{
7 Gode et.al. 2011, 60
}

8 Gode et.al. 2011, 126. 


\section{Short facts}

Additional biogas is transported via pipe line to the Måbjerg CHP plant on adjacent ground, and any additional biogas is utilized in Måbjerg BioEnergy's two biogas generators providing energy for the plant itself.

Why a methane abatement measure: One of the largest biogas plants in the world with a good example of pipeline for manure and digested sludge distribution which reduces the methane slip from storage and transportation of digested sludge.

Yearly methane reduction: The methane reduction from the plant is mainly due to two factors:

- Replacement of electricity and heat produced from fossil sources about 63 tonnes methane per year

- Reduction of diffuse small methane emissions by distribution by pipeline

\section{Contact information}

Contact person:

Thomas Maxe, MAXEffekt PR \&

Kommunikation

Phone number:

+4541572157

E-mail:

info@maxeffekt.dk

\section{Barriers and difficulties}

Mjaaberg BioEnergy has been working on the idea for more than ten years and has accumulated experience during this time. They have now started a consulting business, MBE Consulting to help others who intend to start a biogas plant. Their advice to start a successful business is to look at the big picture for a biogas plant: and address the following questions:

- How much energy can you sell? To whom? And how will you distribute it?

- Can you place your biogas plant close to other energy plants to reduce distribution costs?

- Will you be able to use biomass fiber for heat and power production?

- How much biomass will you need to gather to produce sufficient energy?

- How will you balance a steady supply with storage facilities?

- How will you handle the logistics to collect raw material from farms?

- How will you return wet segment fertilizer to the farms? 


\subsection{Small scale biogas production from manure, potatoes and flour for electricity and heat production}

Plant: Lövsta, SLU, Swedish University of Agricultural Science

Location: Uppsala, Sweden

Start-up year: 2012

\section{Technical description}

The biogas plant is located next to SLU's own farm with stables for pigs and cattle. The manure is pumped directly to the biogas plant and the heat and electricity produced from the biogas is used in the livestock stables.

An overview of the plant is shown in figure 10.

\section{Reception and pre treatment}

Manure from the stables is pumped through separate pipelines to buffer tanks at the biogas plant. Biogas substrates from external sources can also be pumped directly into the buffer tanks from tank trucks.

The plant also receives solid substrates such as potatoes from a local farm and waste flour from a mill. The solid substrates are received at a concrete area protected with a sealing and feed with a wheel loader to a mixer that chop and grind the substrate to small particles. The solid substrate is then transported by screw conveyor into the recirculation flow of the digestion tank and then pumped in to the digester.

\section{Digestion tank}

The digestion tank has a volume of $3,600 \mathrm{~m}^{3}$ and is completely mixed using top mounted mixers. The process is continuous and operated at mesophilic temperatures, $37^{\circ} \mathrm{C}$. The digestion tank is isolated and the incoming substrate is pre-heated through heat exchange with outgoing flow and a circulation flow from the digestion tank is heated with central heating. The current hydraulic retention time is around 58 days and the degree of degradation is approximated to around $70 \%$.

\section{Digested sludge}

The digested sludge is cooled via heat exchange with incoming substrate. This slows or stops methane production in the sludge. The storage tanks are covered which reduces ammonia emissions, prevents methane leakage and also reduces the risk of the sun warming the sludge and causing and methane production to restart.

\section{Short facts}

A plant for anaerobic digestion of manure from the own farm together with potatoes and waste flour from a mill. The manure mix consists of cattle, pig and poultry manure. The biogas is used to produce $3.4 \mathrm{GWh}$ of electricity and $3.5 \mathrm{GWh}$ of heat per year. The electricity and heat is used internally within the farm including the biogas process itself. A small amount of excess electricity is exported to the national power grid.

The plant is also a research center for the Swedish University of Agricultural Science.

Why a methane abatement measure: Good example of an efficient complete small scale system for the entire process from manure to production of energy. Methane reduction mainly through production of energy and replacing fossil energy sources.

Yearly methane reduction:

- Approximately reduction of $380 \mathrm{~kg}$ of $\mathrm{CH}_{4}$ from replacement of fossil energy sources.

- Reduction of diffuse emissions from storing of manure in covered storages (not quantified) 


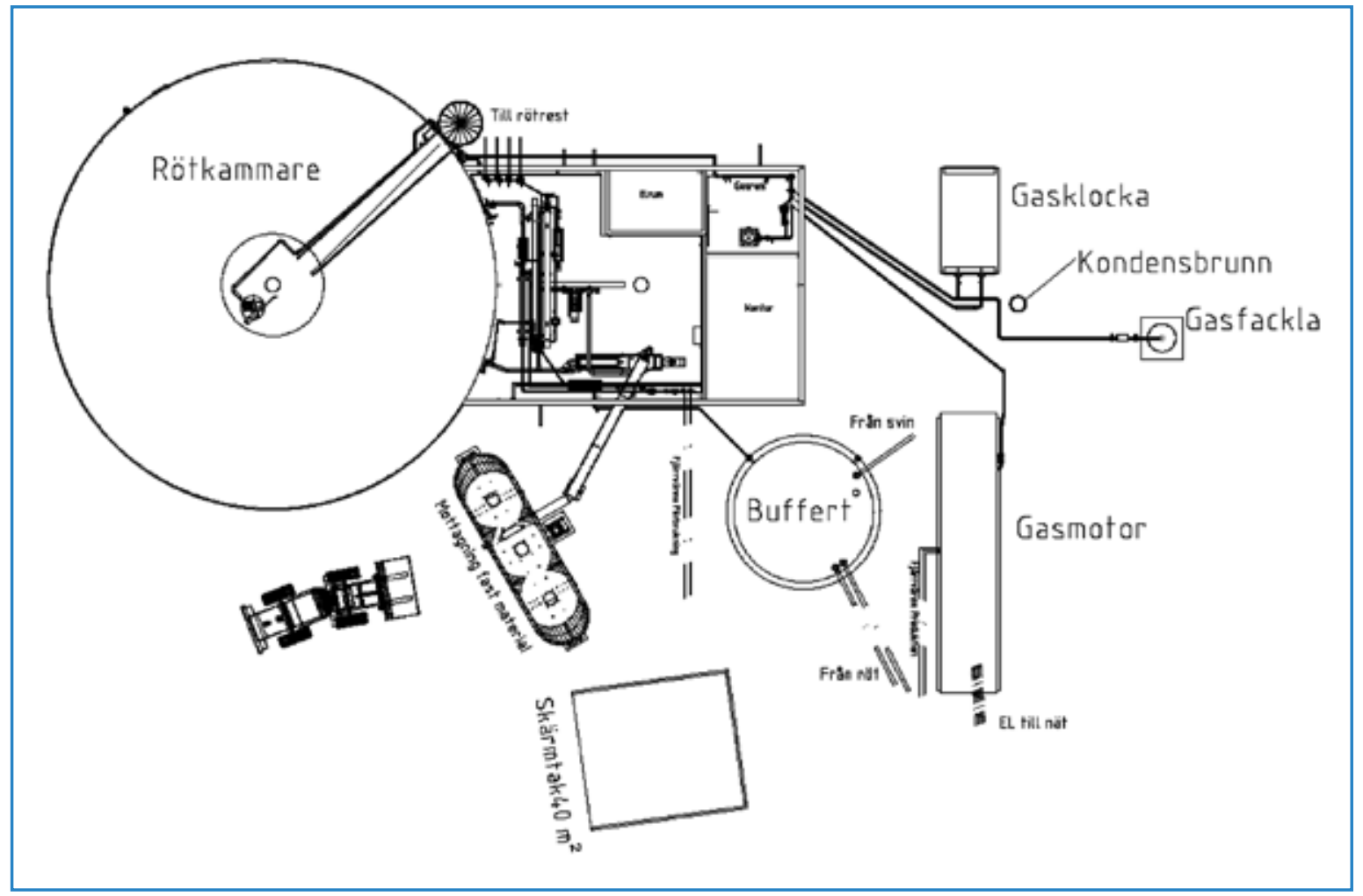

Figure 10 Overview of the plant

Gas system

The produced gas is collected at the top of the digestion tank and lead through a purification filter (active coal) to a gas engine. For reasons of safety, the gas system is also provided with a gas flare.

The engine has an installed power of $1.3 \mathrm{MW}$.

\section{Methane reductions and other benefits}

The plant produces about 1,800,000 Nm³ biogas/year. From this, the engine produces about 3,400 $\mathrm{MWh} /$ year of electricity and about 3,500 MWh/year of heat.

The methane reduction from the plant is mainly due to two factors:

- Replacement of electricity and heat produced from fossil sources

- Covered storage for digested sludge

Replacement of electricity and heat

The total amount of reduced methane from replacement of electricity and heat from fossil fuels is approximated to about $380 \mathrm{~kg} \mathrm{CH}_{4}$ per year. The calculations are based on emission factors adjusted to known facts and assumptions about the plant. If the farm at Lövsta did not have their own biogas plant the assumption is made that they would use combustion of wood chips to produce heat instead of biogas and electricity from the national grid which is assumed to consist of the Nordic power mix. 
The key factors for emissions used are:

\section{Combustion of wood chips, small scale Efficiency of bio boiler \\ Nordic power mix}

$0.0017 \mathrm{~g} \mathrm{CH}_{4} / \mathrm{MJ}^{9}$

$80 \%{ }^{10}$

$0.11 \mathrm{~g} \mathrm{CH}_{4} / \mathrm{kWh}^{11}$
9 Gode et.al. 2011, 32.

10 Gode et al. 2011, 32.

11 Gode et.al. 2011, 126
The plant produces about 3,400 MWh electricity each year of which $6 \%$ is used within the biogas process. The remaining 3,200 MWh is assumed to replace the use of electricity from the national grid as mentioned previously. This equates to a reduction of about 351 $\mathrm{kg} \mathrm{CH}_{4}$ per year. About 3,500 MWh heat is produced at the plant of which $9 \%$ is used for the biogas process. The remaining of 3,200 MWh of heat is assumed to replace combustion of wood chips and with the emission factors described above the reduction of methane is calculated to about $24 \mathrm{~kg}$ per year.

\section{Costs}

The total investment for the plant described above is approximately 2.95 million Euro including costs for ground work.

The operating cost for 2013, excluding costs for purchase of substrates, was approximated to about 186 thousand Euros. But this year had a comparatively high maintenance and service costs. The aim is to keep the operational cost on about 145-155 thousand Euros per year.

Annualised costs were calculated to be $430,000 € / \mathrm{yr}$

Based on the assumptions presented in section 3, and figures in 4.3, the cost effectiveness of the Lövsta plant, as a means to reducing methane emissions, is $5,085 € /$ ton $\mathrm{CH}_{4}$.

\section{Barriers and difficulties}

Over all the plant has been working well since the start. The operational costs have been slightly higher than expected due to higher need for maintenance and service than promised by the contractor.

One operational difficulty has been problems with the pumps into the digestion chamber. The advice from the plant owner is to make sure to purchase pumps constructed for manure and not for waste water treatment or other "easier" substrate.

\section{Contact information}

Contact person:

Jakob Källström, SLU

Swedish University of

Agricultural Science

Phone number:

+ 46706491907

E-mail:

Jakob.kallstrom@slu.se 


\subsection{Biogas production from solid horse manure}

\section{Short facts}

Sötåsen is a biogas plant run by a Natural Resource High school in Sweden. The plant mainly digests manure from cattle and has been in operation since 2008. The plant produces about $80,000 \mathrm{Nm}^{3}$ biogas per year which is used to produce heat and power.

During the years 2012-2014 JTI, Swedish Institute of Agricultural and Environmental Engineering, performed full-scale tests with digestion of solid horse manure at the plant and observed positive results. The technique involves a process of mixing solid manure with liquid manure to achieve efficient co-digestion with a high admixture of solid manure.

Why a methane abatement measure: There are few anaerobic digestion plants that process solid manure in any large quantities or high proportion. The possibility to digest solid horse manure will open up for a wider implementation of abatement measures that reduce the methane emission from all types of solid manure.
Plant: Sötåsen and JTI

Location: Töreboda, Sweden

Start-up year: The plant 2008 and the try-out with solid manure 2012-2014

\section{Technical description}

\section{The process at Sötåsen today}

The plant consists of two anaerobic digestion tanks (AD-tank) each with a volume of $260 \mathrm{~m}^{3}$ installed in series. The first AD-tank is equipped with two stirrers, one CRI-MAN fast rotating and frequency controlled bottom mixer ( $5.5 \mathrm{~kW}$ ) with continuous operation and one Suma Giant mix surface mixer (11 kW) with intermittent operation. The second AD-tank only has the surface mixer. Before the tanks there are two different input lines, one for pumpable substrates and one for solid substrates. The AD process is performed at mesophilic temperature, about $38-41^{\circ} \mathrm{C}$, in the first digestion tank. The first tank is isolated both under and above ground and has heating coils to maintain the right temperature. The second tank is more of a post digestion tank, it's not isolated and is fitted with a heat exchange system for effective cooling. During summer the temperature can be lowered to about $30^{\circ} \mathrm{C}$ and during winter to about $20^{\circ} \mathrm{C}$ and the excess heat is used to pre-heat incoming raw material.

The gas is mainly used for power production in an Otto engine $\left(10 \mathrm{Nm}^{3} / \mathrm{h}\right)$, excess gas is used in a gas boiler for heat production (7-10 $\left.\mathrm{Nm}^{3} / \mathrm{h}\right)$ or in case of brake down burnt in a flare.

An overview of the AD-process is shown in figure 11.

\section{Full-scale tests with horse manure}

The objective with the study was to enable future further implementation of co-digestion of liquid and solid horse manure with a high proportion of solid manure. The aim with the full scale tests was to gain practical experience of digestion of solid horse manure. In addition to the full scale test lab scale tests was carried out with the aim to examine how different bedding material effect the biogas production. Economic aspects were also examined. 


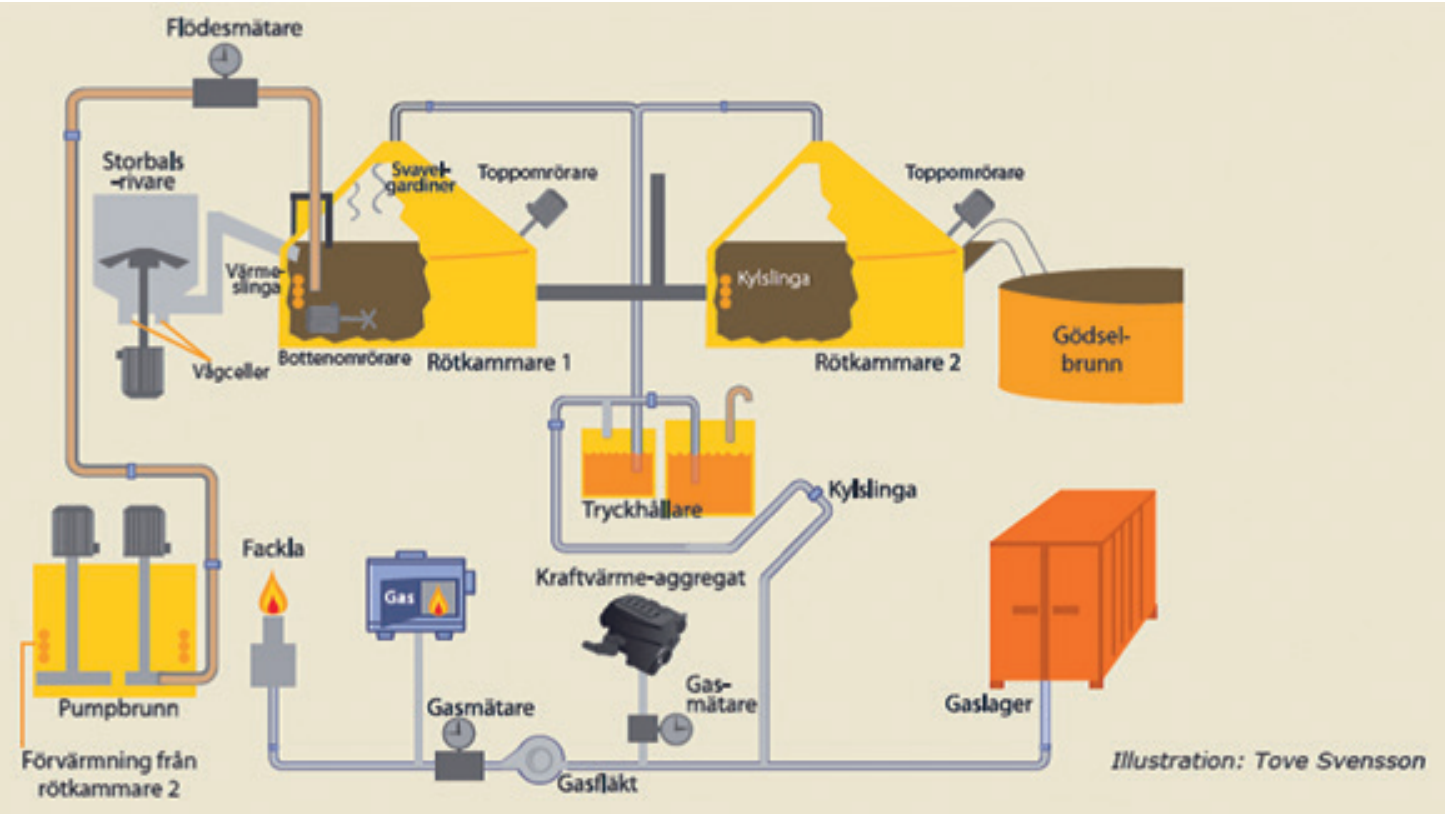

Figure 11 Overview of the anaerobic digestion process at Sötåsen

During the full scale test about 250 tonnes solid horse manure was co-digested with liquid manure from 60 dairy cows according to the table below.

\begin{tabular}{lcccc}
\hline & Period & $\begin{array}{c}\text { Total amount of } \\
\text { horse manure }\end{array}$ & $\begin{array}{c}\text { Horse } \\
\text { manure }\end{array}$ & $\begin{array}{c}\text { Liquid } \\
\text { manure }\end{array}$ \\
\hline $\begin{array}{l}\text { Sawdust as bedding } \\
\text { material }\end{array}$ & $\begin{array}{c}2013-05-22 \\
2013-08-30 \\
(100 \mathrm{~d})\end{array}$ & 120 tonnes & 1.2 tonnes/day & 4 tonnes/day \\
& & & & \\
$\begin{array}{l}\text { Straw pellet and } \\
\text { sawdust as bedding } \\
\text { material }\end{array}$ & $\begin{array}{c}2013-08-30 \\
2013-11-19 \\
(81 \mathrm{~d})\end{array}$ & 134 tonnes & 1.6 tonnes/day & 7 tonnes/day \\
\hline
\end{tabular}

Table 8 Summary of experimental design.

In order to co-digest the liquid and solid manure the solid horse manure has to be mixed together with some liquid, in this case digestate, to a pumpable slurry. Before the slurry is fed into the digestion reactor sand and gravel is separated through sedimentation.

During summer when dairy cows are pasturing accessible liquid manure decreases and biogas production normally goes down. During the summer of 2011 the average methane production during summer was about $100 \mathrm{~m}^{3}$ per day, digesting only liquid manure. When performing the full scale tests with solid horse manure over $170 \mathrm{~m}^{3}$ methane was produced in average per day. 


\section{Short facts}

Handling of horse manure is a growing problem in Sweden and is a significant expense in the equine industry. The possibility to digest the manure has potentially economic benefits and delivers a better plant nutrient quality in addition to reducing methane emissions and providing renewable energy.

Yearly methane reduction from digesting horse manure: It is estimated that methane emission reduction is about $40 \%$ higher when co-digesting dairy cow manure with solid horse manure as a complement during pasteurization season when biogas production normally goes down.

Table 9 Overview of methane emission reduction at Sötåsen during test period.

12 Gode et.al. 2011, 126.

13 Gode et.al. 2011.
Lab scale test showed methane production was strongly dependent on bedding material. Straw as bedding material result in the highest potential methane yield while saw dust or peat result in about half the potential methane yield. From the full scale test the saw dust or pelletized straw has proven to be easier to handle and cause less operational disruption.

\section{Methane reductions and other benefits}

In the calculations of methane reduction, results from anaerobic digestion of horse manure with saw dust as bedding material, has been used. Liquid dairy cow manure is set to have a methane yield of $14.3 \mathrm{Nm}^{3} /$ tonnes manure and horse manure $18.4 \mathrm{Nm}^{3} /$ tonnes manure.

\begin{tabular}{lcc}
\hline $\begin{array}{l}\text { Estimated biogas production } \\
\text { during test period }\end{array}$ & Only liquid manure & $\begin{array}{c}\text { Co-digestion with solid } \\
\text { horse manure }\end{array}$ \\
\hline $\begin{array}{l}\text { Methane production during 181 d } \\
\left(\mathrm{Nm}^{3} \mathrm{CH}_{4}\right)\end{array}$ & 13,800 & 22,400 \\
$\begin{array}{l}\text { Total energy content in gas (kWh) } \\
\text { Estimated power production (kWh) }\end{array}$ & 137,600 & 223,300 \\
$\begin{array}{l}\text { Estimated heat production (kWh) } \\
\text { Intern power consumption (kWh) }\end{array}$ & 68,800 & 111,700 \\
$\begin{array}{l}\text { Intern heat consumption (kWh) } \\
\text { Excess power (kWh) }\end{array}$ & 106 & 100,500 \\
$\begin{array}{l}\text { Excess heat (kWh) } \\
\text { Emission reduction calculations }\end{array}$ & 20,600 & 126 \\
$\begin{array}{l}\text { Reduced methane emission, power } \\
\text { (kg per 181 d) }\end{array}$ & 68,700 & 25,900 \\
$\begin{array}{l}\text { Reduced methane emission, heat } \\
\text { (kg per 181 d) }\end{array}$ & 41,300 & 111,600 \\
$\begin{array}{l}\text { Total methane emission reduction } \\
\text { (kg per 181 d) }\end{array}$ & 0,3 & 74,600 \\
\hline
\end{tabular}

Co-digestion with solid horse manure reduces methane emission with $13 \mathrm{~kg}$ per 181 days witch is applied to $24 \mathrm{~kg}$ per year. In reality this will differ since the conditions for methane gas production will vary over the year.

These standard emission values have been used to calculate emissions:
Nordic power mix
$0.11 \mathrm{~g} \mathrm{CH}_{4} / \mathrm{kWh}$ electricity ${ }^{12}$
Boiler (wood fired) $0.00765 \mathrm{~g} \mathrm{CH}_{4} / \mathrm{kWh}$ prod heat ${ }^{13}$

\section{Costs}

Investment for the present biogas plant is about 5.9 million SEK (about 0.6 million Euro). Annualised investment cost for the plant with Co-digestion with solid horse manure was 56,600 euro. Information on running costs was not provided. 
From the economical evaluation it is possible to read out that digestion of solid horse manure using straw pellet or chopped straw as bedding can be economically viable. Favourable conditions such as already existing feeding system for solid manure or exemption from pasteurization demands is important for the economic profitability.

Based on the assumptions presented in section 3, and figures in 4.4, the cost effectiveness of the Sötåsen plant, as a means to reducing methane emissions, is $17,300 € /$ ton $\mathrm{CH} 4$. This may be compared to the cost effectiveness of a similar sized plant for digestion of liquid manure which was calculated to be $43,900 € /$ ton $\mathrm{CH} 4$.

\section{Barriers and difficulties}

Some of the experiences and lessons learned from the full scale test are listed below:

- Sanitation aspects are extremely important and have to be carefully considered to avoid contamination and diseases on the farm.

- The sedimentation of sand and gravel is extensive but could possibly be partly avoided with right information and handling of the horse manure at the horse farm.

- Handling and feeding of horse manure takes longer time than handling of liquid manure and consumes more energy sense it has to be mixed to slurry.

- A barrier is the technical limitations of the equipment f.eg. the feeding system, blending proportion and viscosity that affect the possibility to effective mixing.

- A good market for the produced power, heat, and plant nutrients is important.

- Big technical challenges are the mixing in the reactor and the demand for pasteurization ${ }^{14}$ when manure from several farms is to be digested. The poor heat exchange properties due to high TS-ratio risk to make pasteurization very energy demanding.

- A fairly large number of horses are needed in order to generate manure enough to build a profitable anaerobic digestion plant.
14 This is due to Swedish legislation regarding animal bi-products.

\author{
Contact information \\ Contact person: \\ Henrik Olsson, \\ JTI- Swedish \\ Institute of Agricultural \\ and Environmental \\ Engineering \\ Phone number: \\ +46(0)10-5166936 \\ E-mail: \\ Henrik.Olsson@jti.se
}




\subsection{Small scale local biogas production with gas distribution pipelines to collective upgrading plant}

\section{Short facts}

The project is a unique constellation of cooperation between municipalities and farmers where biogas is produced from manure locally at different farms.

Manure from 10 different farms, waste from slaughter houses and waste from vegetables are digested at 4 different plants located at regional farms. The biogas plants are connected by pipelines to distribute the raw gas to a joint upgrading plant. The upgraded gas is then distributed by another pipeline to a compressor and vehicle fuel filling station.

At full capacity the plants produce 1.7 million $\mathrm{Nm}^{3}$ upgraded gas. The upgraded gas is mainly used for buses in the region.

\section{Why a methane abatement} measure: Good example of cooperation of municipalities and farmers to produce biogas from a number of small scale production facilities with a distribution through a pipeline to a joint upgrading plant. The method makes upgrading possible even from small farms and the pipeline system reduces methane emissions.
Plant: Biogas Brålanda

Location: Brålanda, Sweden

Start-up year: 2012

\section{Technical description}

The system consists of four different biogas plants located at four different farms. The substrates for digestion are mainly liquid manure from the own farms and also manure delivered from six other close by farms. A few of these farms are connected by a pipeline and the manure is pumped to the digestion plant. Some of the plants also receive slaughterhouse waste and waste from vegetables. The geographical overview of the pipeline system is shown in figure 12 .

The four different production plants are connected by a raw gas pipeline to a joint upgrading plant. The pipeline consists of $4.6 \mathrm{~km}$ main distribution line and a $14 \mathrm{~km}$ raw gas pipeline. The pipeline has a varied diameter, 63-160 mm.

There is also a raw gas pipeline to the slaughterhouse that delivers waste. The slaughterhouse uses a small amount of gas in their gas boiler for energy production. The rest of the gas is upgraded to vehicle fuel at the upgrading plant and distributed through a pipeline to a compressor and a vehicle fuel filling station. In total the biogas production plants have a capacity to produces about 1.7 million $\mathrm{Nm}^{3}$ upgraded gas each year. The plan is to reach full capacity in a few years.

The distribution of biogas in a pipeline system has been evaluated in the report Pumpning av gödsel och biogas i markledning, by Anders Broberg at Innovatum.

In the report there are also studies of pumping of manure and digested manure presented. Three different tests have been performed for two of the pipelines:

- Pipeline Berg- BergUngen, length 2,700 m, outer diameter $180 \mathrm{~mm}$, inner -diameter $158.6 \mathrm{~mm}$. Total altitude difference $1 \mathrm{~m}$.

1. Pumping pig manure from Berg to BergUngen

2. Pumping digested manure from BergUngen to Berg

- Pipeline BergUngen-Säby, length 1,500 m, outer-diameter 90 mm, inner-diameter $73.6 \mathrm{~mm}$

1. Pumping digested manure from BergUngen to Säby 


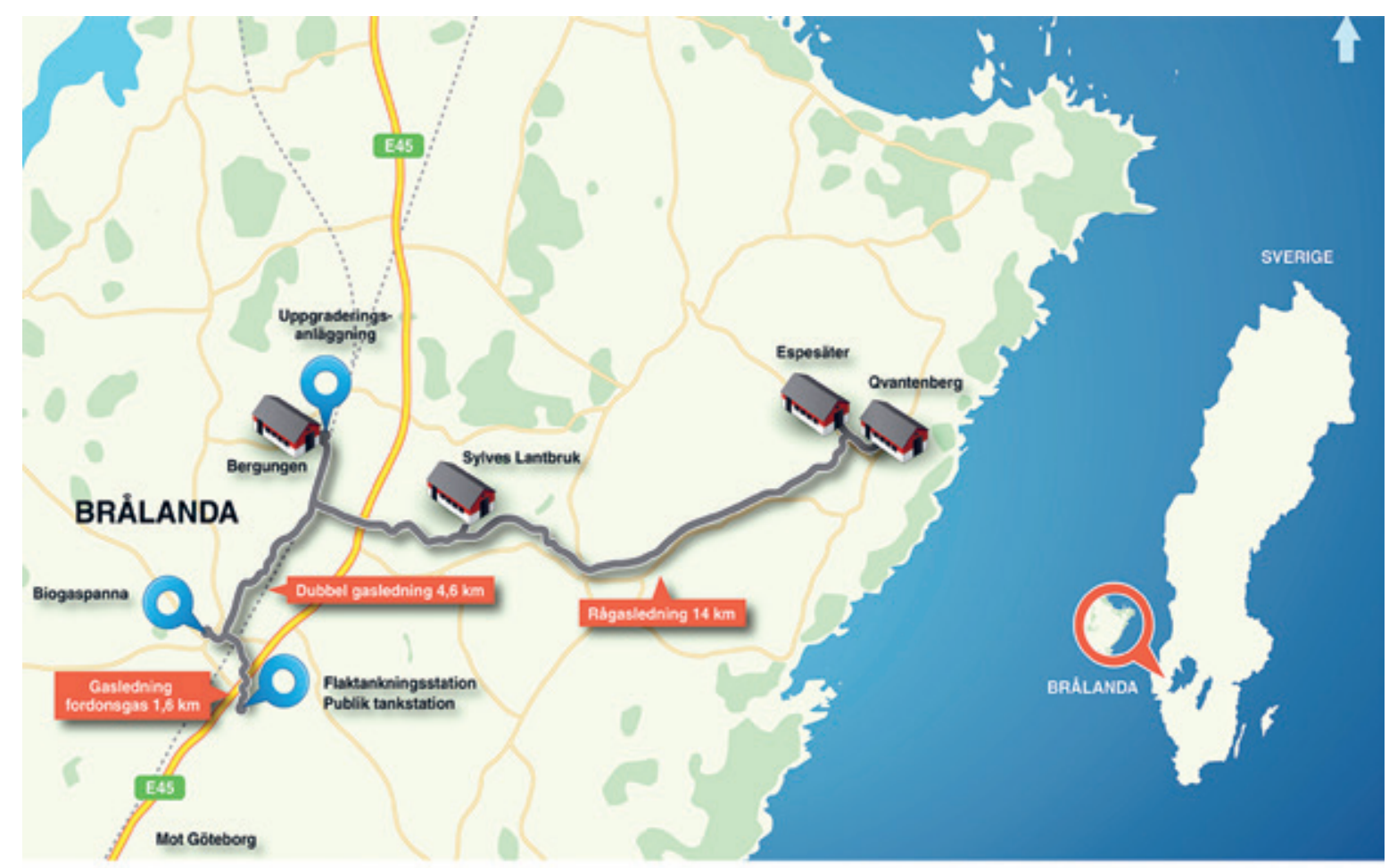

Figure 12 The geographic overview of the gas distribution system in Biogas Brålanda

For all studies a tractor (New Holland 7060, $250 \mathrm{hp}$ ) and a tractor driven pump from Astimac (Bauer Magnum SX 1000, $140 \mathrm{~m}^{3} / \mathrm{h}$ ) were used. The pipelines were cleaned using compressed air.

In the studies the pig manure held a dry substance content of $4.7 \%$ and the digested manure $3.2 \%$ dry substance.

The pumping of manure in all tests turned out well and after the tests the pipelines have been in use and are working as expected.

\section{Methane reductions and other benefits}

The plant produces about $1,700,000 \mathrm{Nm}^{3}$ upgraded biogas/year.

The methane reduction from the plant is mainly due to:

- Replacement of fossil fuel

- Reduced small diffuse emissions of methane with the pipeline system both for manure and gas dristribution

\section{Replacement of fossil fuel}

The total amount of reduced methane from replacement of fossil fuels is approximated to about 2 tonnes $\mathrm{CH}_{4}$ per year.

\section{Short facts}

Yearly methane reduction:

- Approximately reduction of 2 tonnes of $\mathrm{CH}_{4}$ from replacement of diesel.

- Reduction of diffuse emissions from distribution of manure and gas through pipeline systems (not quantified) 


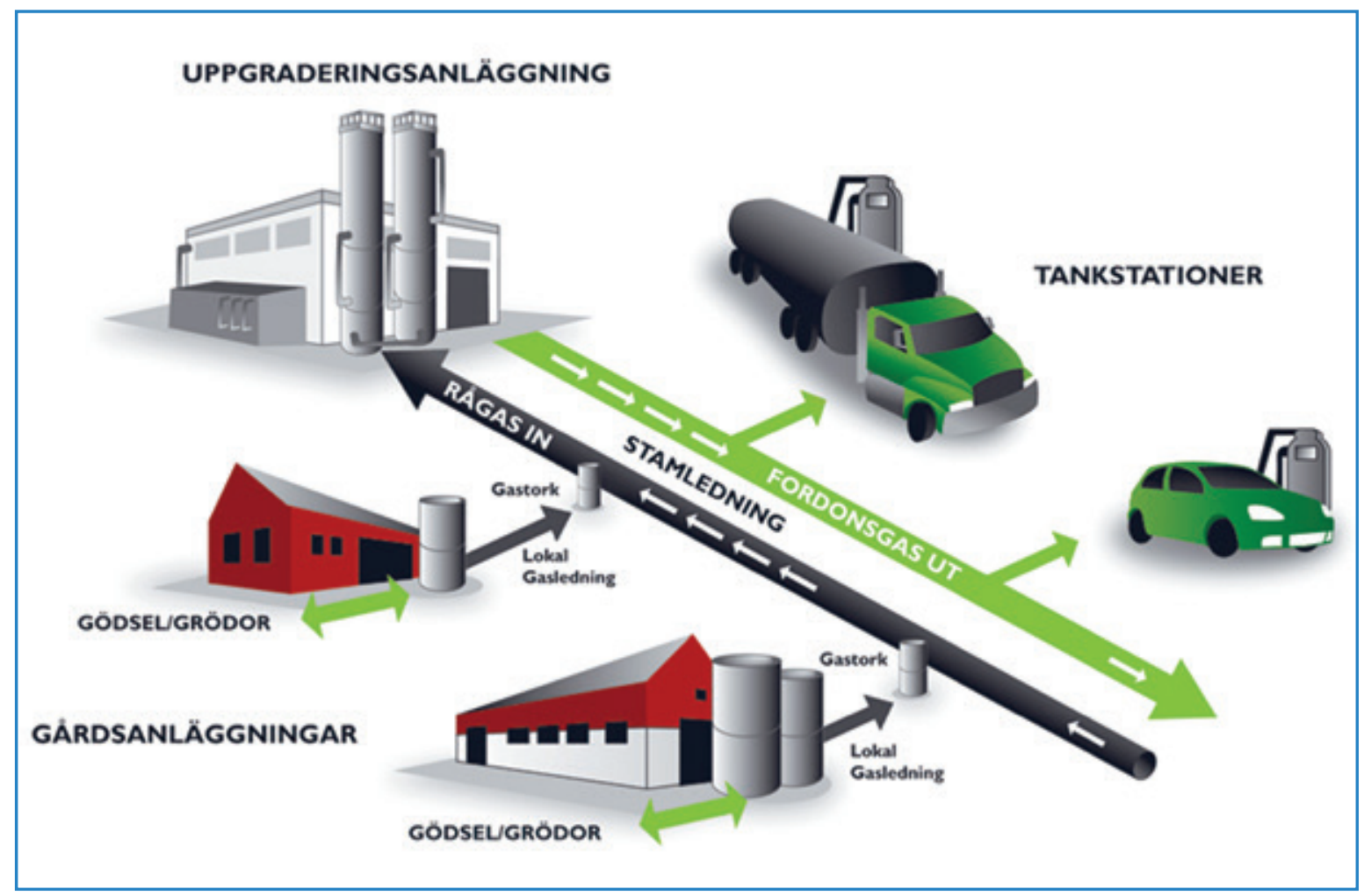

Figure 13 Overview of the pipeline system

The calculations are based on emission factors for production and utilisation of diesel for buses. The key factors for emissions used are:

\section{Production and utilisation of diesel, bus $\quad 0.034 \mathrm{~g} / \mathrm{MJ}^{15}$}

\section{Other benefits}

The project has given other positive effects on the society such as more jobs in the region. Workers are needed at the actual plants but also a new company for maintenance has started as a direct effect of the project and also a new consultant company specialized in biogas.

Economically there are other effects such as more tax refunds will stay within the region and also a sense of satisfaction and ownership is created with own locally produced biogas.

The business model

The business model for the project is unique and has been one of the main factors for the successful project.

The project is owned by Biogas Brålanda $A B$ and Biogas Brålanda net incorporated company. An overview of the business model is shown in figure 14. 


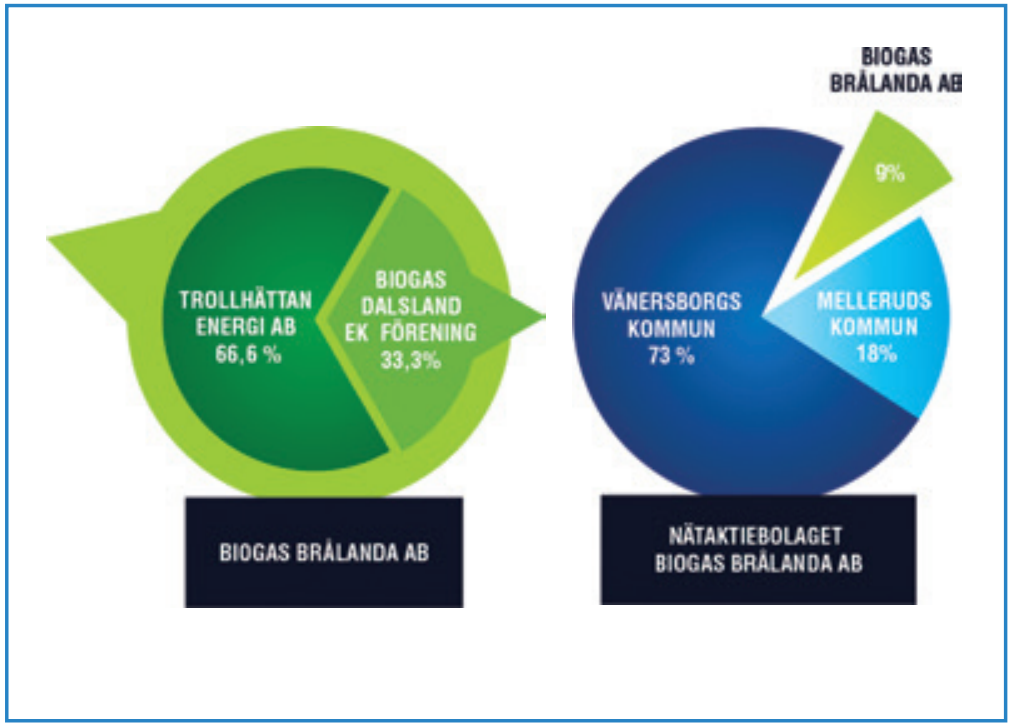

Biogas Brålanda $A B$ is owned by a local municipal energy company Trollhättan Energi and Biogas Dalsland which is owned by the local farmers and certain interested private investors. Biogas Brålanda net incorporated company is owned by the municipalities of Vänersborg and Mellerud and Biogas Brålanda AB.

The system is then divided into different ownership:

- The upgrading plant and filling stations are owned by Biogas Brålanda $A B$

- The system of gas pipelines (biogas into the upgrading plant and vehicle fuel out) are owned by Biogas Brålanda net incorporated company

- The four digestion plants are each owned by a single farm or a cooperation between several farms

\section{Costs}

The investment for the gas distributing system (excluding pipeline) are estimated to about 510,000 SEK (53,000 Euro). This includes gas-flow meter, gas analyses, dewpoint transmitter, chiller, absorption drier, gas compressor.

The yearly operational cost for measuring, drying and pressure increase of the gas is estimated to 0.2 Euro/kWh.

Pipeline for manure Berg- BergUngen, 2,700 m, investement 1 million SEK (100,000 Euro).
Figure 14 The business model of Biogas Brålanda 
Pipeline for digested manure BergUngen-Säby, 1,500 m, investment 180,000 SEK (19,000 Euro).

The above mentioned costs do not include costs for digestion of manure and upgrading of the raw biogas. Typically digestion costs are around $0.03 € / \mathrm{kWh}$ and the cost for upgrading the gas to vehicle fuel quality typically costs around $0.01 € / \mathrm{kWh}$. Based on this and the above mentioned costs, the annualised investment cost for the plant is $743,500 € / \mathrm{yr}$

Thus, based on the assumptions presented in section 3, and figures in 4.5, the cost effectiveness of the Brålanda project, as a means to reducing methane emissions, is $6,250 € /$ ton $\mathrm{CH} 4$.

\section{Barriers and difficulties}

There has been a long process, about 8 years, from the first start up meetings to the final plant being in operation. Since there are not very many projects like Biogas Brålanda in operation there were no real experiences to learn from. Many of the discussions in the planning phase were addressing risks and in particular who should take different risks. The winning concept seems to be the business model which was incorporated due to the way in which risk is divided.

Another problem not foreseen from the start has been the long start up time for the biological processes at the four biogas plants. It has taken two years and a lot of consultation with experts to reach almost full output.

\footnotetext{
Contact information

Contact person:

Karin Stenlund, Fyrbodals

kommunalförbund

Phone number:

$+46522440868$

+ 46703944839

E-mail:

karin.stenlund@fyrbodal.se
} 


\subsection{Landfill gas collection system and upgrading}

Plant: Álfsnes, SORPA

Location: Reykjavík, Iceland

Start-up year: Collection of gas 1996, pilot upgrading plant 2000, upgrading plant 2005

The Álfsnes landfill site is the largest landfill site in Iceland and where waste from the whole Reykjavik area is deposited. In 1996 collection of gas from the landfill started but at that time the collected gas was channelled to a flare. In 2005 SORPA opened a new gas refining and production plant at Álfnes to clean the gas for use as vehicle fuel.

\section{Technical description}

The upgrading plant in Álfsnes relies upon water scrubbing technique to separate the carbon dioxide $\left(\mathrm{CO}_{2}\right)$ from the collected landfill gas. Figure 15 shows a schematic view of the upgrading process.

The landfill gas from the gas collection system enters the upgrading plant saturated at gauge pressure $250 \mathrm{mbar}$ and $20^{\circ} \mathrm{C}$. The gas is cooled at the inlet and condensate separated from it.

Three gas compressors are used for parallel compression of the gas up to gauge pressure 20 bar and the gas then enters one of two scrubbing columns in the plant. The gas is washed with water in the scrubbing column and the water absorbs $\mathrm{CO}_{2}$ from the gas. The water is led through a flashing tank to reclaim methane before being stripped of $\mathrm{CO}_{2}$ and recirculated.

The gas is upgraded to vehicle fuel quality (about $95 \% \mathrm{CH}_{4}$ ). The landfill gas contains nitrogen in small quantities that remains in the gas after scrubbing. After the scrubbing, the gas is dried in one of two adsorption drying units. The dew point after drying is about $-25^{\circ} \mathrm{C}$ at 250 bar.

After odorizing the gas it is either compressed up to 250 bar for refilling of transportation units in Alfsnes or transported at gauge pressure 9 bar by a $10 \mathrm{~km}$ pipeline to a refuelling station in Reykjavik.

\section{Landfill}

Short facts

Álfsnes is the largest landfill site in Iceland and has a modern gas collection system. Most of the collected biogas is upgraded and used as vehicle fuel. The gas not used for vehicle fuel is flared.

Why a methane abatement measure: The site with the collection system and upgrading plant is a good example of a efficient system for gas collection and use from landfill sites.

Yearly methane reduction:

- Approximately reduction of 2.4 tonnes of $\mathrm{CH}_{4}$ from replacement of diesel.

- Reduced leakage of methane gas from the landfill 2,506 tonnes $\mathrm{CH}_{4}$

The plant is shown in figure 16. 


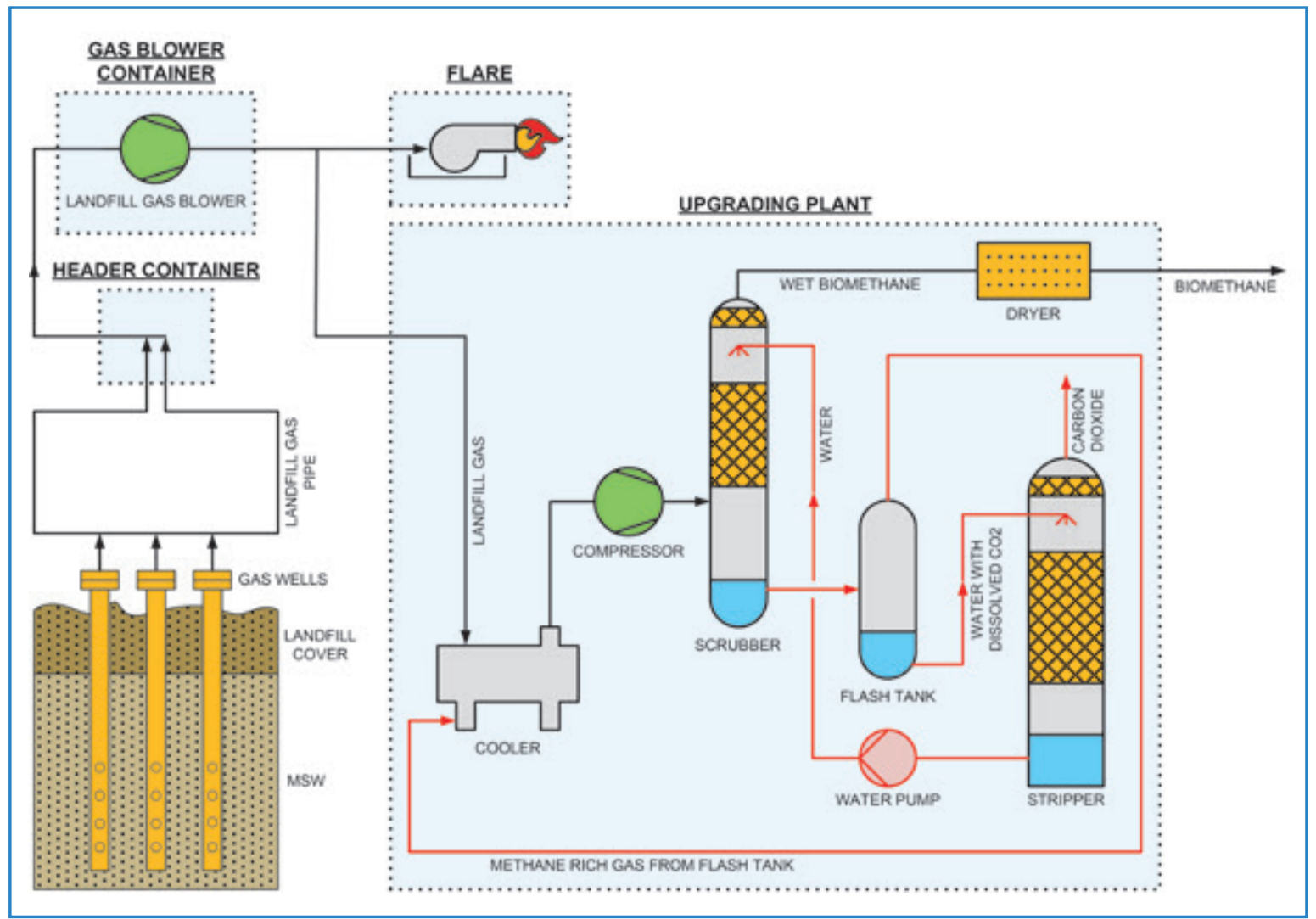

Figure 15 Schematic process flow diagram of the landfill gas upgrading process

\section{Methane reductions and other benefits}

The upgrading plant designed capacity is about $1,000 \mathrm{Nm}^{3} / \mathrm{h}$ of compressed methane gas. Annual production is just over $2,000,000 \mathrm{Nm}^{3}$ of compressed methane gas. The produced methane gas from landfill gas is used as vehicle fuel.

The methane reduction from the plant is mainly due to:

- Replacement of fossil fuel

- Reduced leakage of methane gas from the landfill (not quantified)

Replacement of fossil fuel

The total amount of reduced methane from replacement of fossil fuels is approximated to about 2.4 tonnes $\mathrm{CH}_{4}$ per year. The calculations are based on emission factors for production and utilisation of diesel for buses. The key factors for emissions used are:

Production and utilisation of diesel, bus

Amount of methane used as fuel

Energy content of methane fuel

Methane reduction due to less diesel use
$0.034 \mathrm{~g} / \mathrm{MJ}^{16}$

1,432 tonnes/year

71,600,000 MJ

2.4 tonnes $\mathrm{CH}_{4} /$ year 


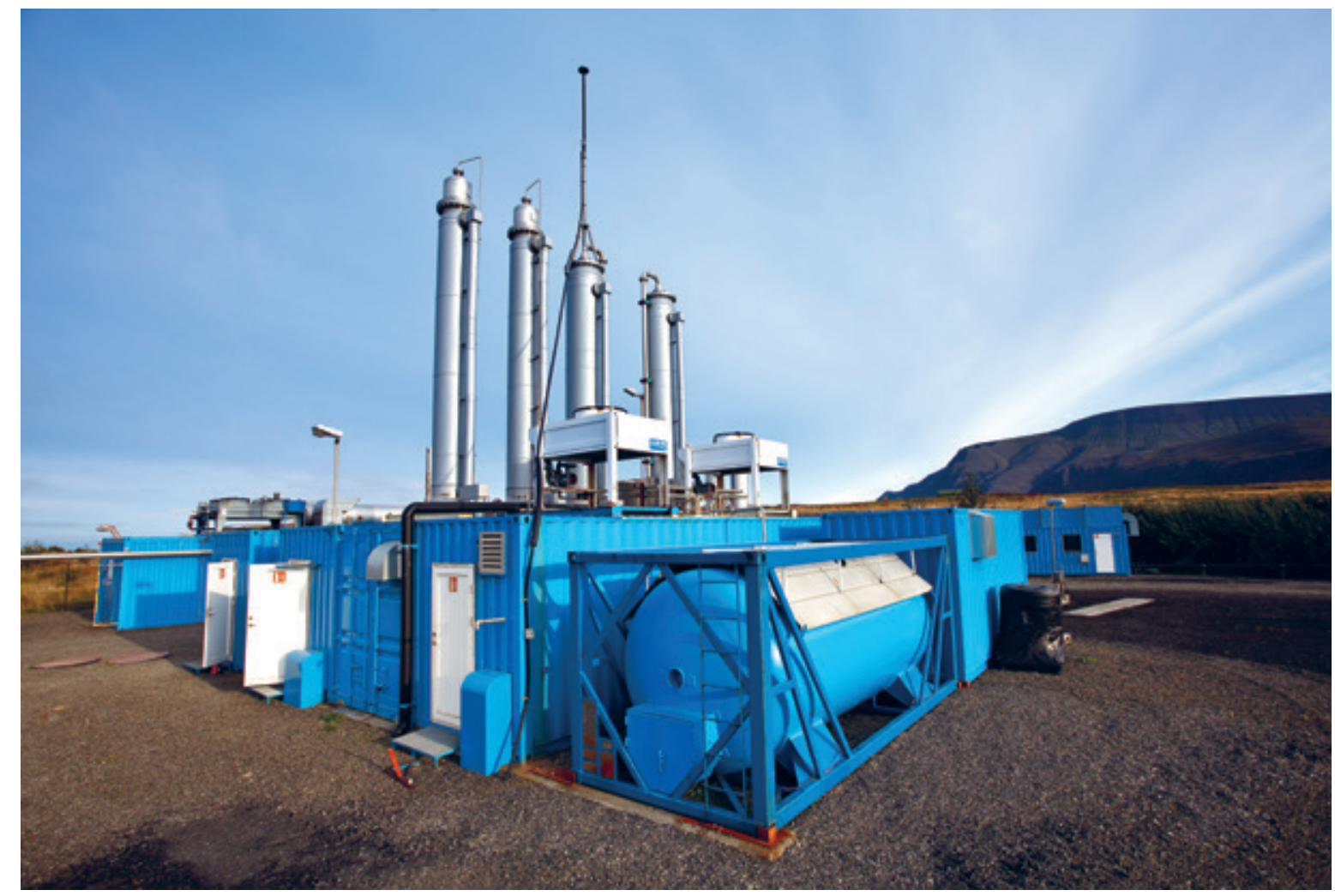

Figure 16 Landfill gas upgrading plant in Alfsnes

The total amount of reduced carbon dioxide emissions from replacement of fossil fuel is approximately $5,300 \mathrm{t} / \mathrm{y}$ of $\mathrm{CO}_{2}$. The calculations are based on emission factors for busses ${ }^{17}$. The produced methane gas from landfill gas is used as vehicle fuel.

$\begin{array}{ll}\text { Production of methane fuel for vehicles } & 2,000,000 \mathrm{Nm}^{3} / \mathrm{y} \\ \text { Amount of methane used as fuel } & 1,432 \mathrm{tonnes} / \mathrm{y} \\ \text { Energy content of fuel } & 71.6 \mathrm{TJ} \\ \text { Emission factor for diesel fuel } & 74,100 \mathrm{~kg} / \mathrm{TJ} \\ \text { Total amount of reduced } \mathrm{CO}_{2} \text { emission } & 5,305 \mathrm{tonnes} / \mathrm{y} \mathrm{CO}\end{array}$

Reduced leakage of methane gas from landfill

The total amount of reduced methane leakage from the landfill as equal to the amount produced and amount flared. The calculations are based on emission factors for methane losses. The key factors for emissions used are:

Production of methane fuel for vehicles Amount of methane flared Total amount reduced leakage
$2,000,000 \mathrm{Nm}^{3,18}$ $1,500,000 \mathrm{Nm}^{3}$

2,506 tonnes/year $\mathrm{CH}_{4}$
172006 IPCC Guidelines for Greenhouse Gas Inventories. 18 SORPA's bookkeeping. 


\section{Costs}

The upgrading plant was built in 2005. Since then the plant has been expanded with increased capacity. Total investment is around 400 million ISK (about 2.6 million Euro).

Annualised costs were calculated to be $306,777 € / y$ r. No information was provided on running costs and thus a typical figure of $25 \%$ of annual investment cost was assumed.

Based on the assumptions presented in section 3, and figures in 4.6, the cost effectiveness of the Alfsnes plant, as a means to reducing methane emissions, is $285 € /$ ton $\mathrm{CH} 4$.

\section{Barriers and difficulties}

The landfill gas upgrading plant has proved to be reliable and has been operated without any major difficulties. The equipment requires regular maintenance and the packing material in the columns needs to be inspected on a regular basis. A close monitoring of the system is also important to be able to react quickly to changes in the system.

\section{Contact information}

Contact person:

Björn H. Halldorson, CEO SORPA

Phone number: $+(354) 5202200$

E-mail:

bjorn.halldorsson@sorpa.is 


\subsection{Low- tech bio cover system}

\section{Landfill}

Plant: Klintholm losseplads

Location: Klintholm, Denmark

Start-up year: 2008

The biocover has been established at Klintholm landfill in Denmark in 2009 on the old part of the landfill, which was in operation from 1980 till 1996 and received approximately $485,000 \mathrm{~m}^{3}$ of mixed waste during this period.

Generation of methane at the old part of Klintholm landfill was in April and August 2008 measured to approx. $8.3 \mathrm{~kg}$ methane/h. It was though difficult to separate the contribution of methane from the old part of the landfill from the rest of disposal area and composting activities taking place at the territory of the landfill.

\section{Technical description}

The bio-cover system is basically a filter of biologically active material, compost, built-in in "windows" in the final soil cover of the landfill body.

In the compost layer the natural methane oxidizing bacterial converts the methane to carbon dioxide and water. The $\mathrm{CO}_{2}$ is of biogenic origin and to be seen as greenhouse gas neutral. At Klintholm landfill, the compost filter was built as at $10 \mathrm{~m}$ wide belt on the top of the waste body. The system consists of $0.3 \mathrm{~m}$ thick layer of high permeable (inert inorganic material, e.g. gravel) covered with about $0.7 \mathrm{~m}$ locally produced compost. The layer of inert material is ensuring an even distribution of the gas to the compost layer.

The total area of the bio-cover system required for the total reduction of methane emissions from this part of the landfill was calculated based on the methane oxidation capacity of the compost material used for the filter.

The selected compost for the filter is a mixture of garden-park compost and kitchen compost at a ratio of $7 / 2$. In column tests the daily methane oxidation rate of the mixture was measured to approx. 96 $\mathrm{g} \mathrm{CH}_{4} / \mathrm{m}^{2}$. The daily methane oxidation rate of $50 \mathrm{CH}_{4} / \mathrm{m}^{2}$ was though chosen as a design parameter for the filter. Based on it, the required filter area was calculated to be $4,800 \mathrm{~m}^{2}$. The construction is shown in.

\section{Short facts}

The technique is quite simple, efficient and relatively cost-effective in reduction of methane emission from landfills. It has been successfully implemented at Klintholm landfill in Denmark.

Why a methane abatement measure: The technique shall be used on landfills with rather low but still significant production of landfill gas where other landfill gas management techniques, such as collection and utilisation for energy production or flair are not applicable. It is therefore recommended for old landfills or new landfills receiving rather limited amount of organic waste and consequently having lower landfill gas production rates. 


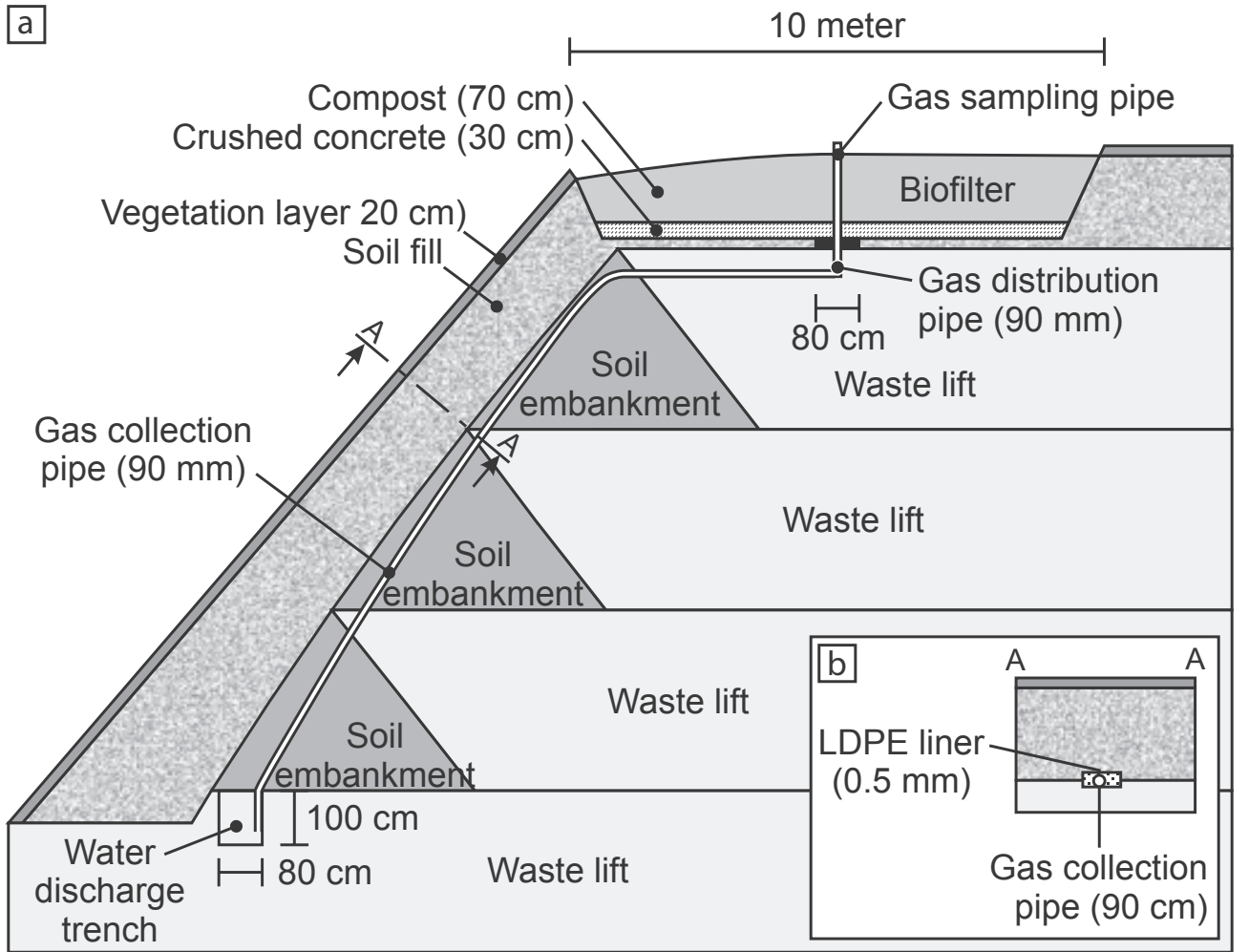

Figure 17 Construction of the bio-cover system. Cross section

\section{Short facts}

Yearly methane reduction:

- The yearly reduction calculates to about 76-129 tonnes of methane per year based on the measurements carried out during the time period 2009-2012, where 76 tonnes per year is the "worst-case scenario". During a 30 year period the methane reduction is calculated to $1,140-1,930$ tonnes of methane equal to 28,580-48,290 tonnes of $\mathrm{CO}_{2}$-eq.
The landfill gas is collected by means of the perforated pipes located under the bio-cover and on the slopes of the landfill body as shown in figure 17. These pipes are placed in trenches having direct contact with the waste and backfilled with coarse inert material, such as shingle stones.

The permeability of the final soil cover is sufficiently low so the landfill gas is directed to the biocover "window" and its content of methane decomposed before leaving the landfill body.

\section{Methane reductions and other benefits}

The project has well documented measurements and reference systems both before and during the implementation of the biocover system.

The measurements have revealed that the total emission of methane has been reduced from approximately $15.7-9.7 \mathrm{~kg} / \mathrm{h}$ to $0.6-1.9 \mathrm{~kg} / \mathrm{h}$. This equals a reduction of $88-94 \%$.

The yearly reduction calculates to about 76-129 tonnes of methane per year based on the measurements carried out during the time period 2009-2012, where 76 tonnes per year is the "worst-case 
scenario". The yearly methane reduction rates are expected to decline gradually following the gas generation rate for the landfill body, which is expected to decline substantially over the next 30 years. During this period the methane reduction is calculated to $1,140-$ 1,930 tonnes of methane equal to $28,580-48,290$ tonnes of $\mathrm{CO}_{2}$-eq.

\section{Costs}

The cost for the construction of the biocover at Klintholm landfill was about 2.4 million DKK (320 thousand Euro).

The cost for monitoring the biocover during the aftercare period of the landfill, which is set to 30 years, is estimated to 3.1 million DKK (420 thousand Euro).

Based on the measurements performed by use of the dynamic plume method the total reduction of methane during this period from the old part of Klintholm landfill can be calculated to an amount equalling the radiative forcing of $\mathrm{CO}_{2}$ - equivalent.

Annualised costs were calculated to be $44,205 € / \mathrm{yr}$. Based on the assumptions presented in section 3 , and figures in 4.7 , the cost effectiveness of the Low tech bio cover, as a means to reducing methane emissions, is $687 € /$ ton $\mathrm{CH} 4$.

\section{Barriers and difficulties}

The biocover project at Klintholm was successful. The majority of the remaining emissions were found to originate from hot spots located in the border area between the biocover and the slope. The reason for this is probably the uneven distribution of gas by the gravel layer.

It is possible that the gas collected by the trenches in the slopes to a large extent is supplied to the part of the biocover closest to the slopes instead of being evenly distributed to the entire area of the biocover. That could mean that in this area the capacity of methane oxidation is exceeded.

As the reduction of methane emission using this technology is achieved due the microbiological processes in the compost filter it can be difficult to control. Knowledge of the landfill gas flow/emission patterns in the waste body and selection of the biologically active compost are crucial factors for achieving the desired results.

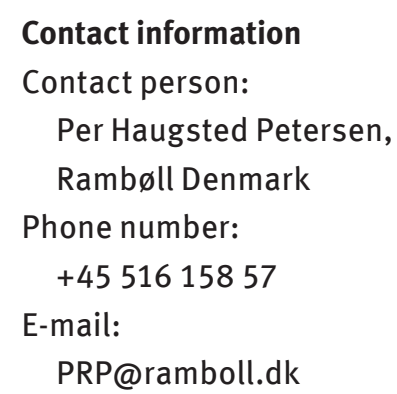




\subsection{Micrometeorological methods for efficient recovery of landfill gas and control of emissions}

\author{
Short facts \\ A major part of the pro- \\ duced landfill gas escapes \\ to the atmosphere through \\ hot spots in the landfill \\ cover layer or landfill gas \\ recovery structures. \\ Active waste disposal \\ areas without cover \\ structures are also large \\ methane gas emitters. A \\ powerful alternative for \\ this kind of heterogeneous \\ environment is the micro- \\ meteorological eddy \\ covariance method, which \\ produces continuous, \\ spatially average data \\ needed for landfill gas \\ emission estimates and \\ monitoring of the perfor- \\ mance of landfill cover \\ structure and landfill gas \\ recovery systems.
}

Why a methane abatement measure:

The project is interesting in how it uses a more accurate gas measurement method and utilizes the data to optimize the gas recovery. In this way it has been possible to use the landfill gas to a further extent.

\section{Calculated yearly methane} reduction

The total methane emissions recovered were in average approximately 160 tonnes per year.
Plant: Päijät-Häme Waste Disposal Ltd.

Location: Lahti, Finland

Start-up year: 2009

\section{Technical case description}

Landfills are significant sources of greenhouse gas emissions, thus landfill gas is usually recovered and treated in the Nordic countries. However in most of the cases landfill gas generation and its recovery rate is rarely determined by representative methods. The micrometeorological method for landfill gas control is a practical tool to be used for landfill design, operation and control of emissions. It has been possible to develop improved gas collection strategies, e.g. increasing the number of landfill gas recovery wells and focussing their location and operation on the basis of data on emissions. The emission measurements have also been used in optimising the performance of the existing landfill gas plants and to evaluate methane generation rate at recently established landfill sites. The recovery rate of the landfill gas system can also be determined. Moreover the micrometeorological flux measurement system includes a direct measurement of evapotranspiration, which helps the control of the water balance of the top cover and the whole landfill.

The particular case, Lahti landfill MSW, has been in operation since the 1950's. In 2002 a landfill gas recovery system (including 26 landfill gas wells) was implemented. The landfill was closed at the end of the 2007 in accordance with the EU landfill directive (1999/31/EC). In 2008 landfill gas emissions caused odour in the neighbourhood, thus landfill gas generation (recovered volume and major components) and emissions were determined by the micrometeorological methods. The objective of this study was to determine total volume of landfill gas generation and its characteristics and to optimize landfills recovery according to data determined.

\section{Micrometeorological method for landfill gas emission control}

The emitted landfill gas was measured using the micrometeorological eddy-covariance method (Baldocchi, 2003), which measures continuously vertical gas mass fluxes of methane, carbon dioxide and water vapour (Laurila et al. 2005; Lohila et al. 2007). It consisted of a 3-d sonic anemometer (METEK USA-1), for measuring three-dimensional wind velocity and air temperature, a carbon-dioxide $\left(\mathrm{CO}_{2}\right)$ and 


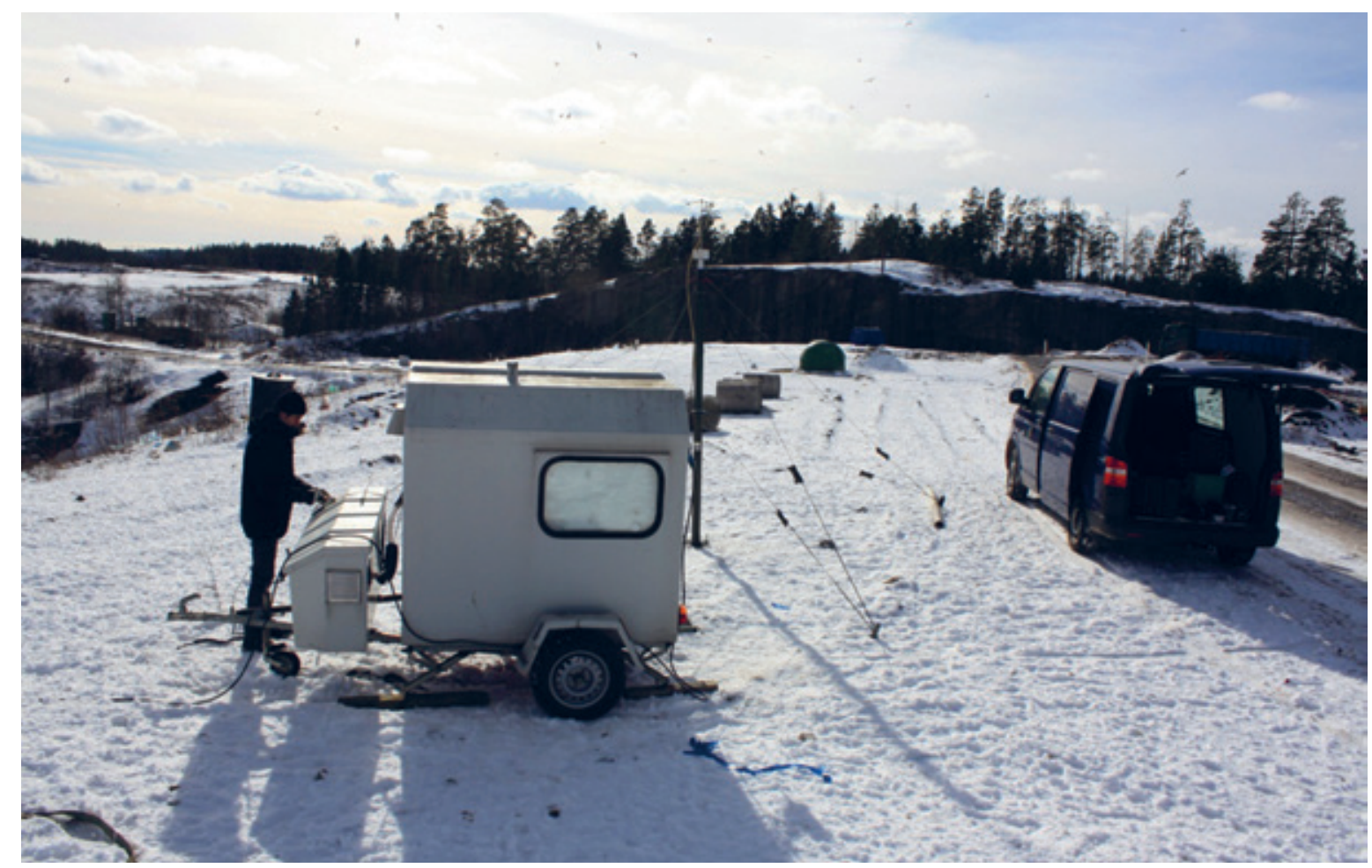

Figure 18 Micrometerological measurement station located at the landfill site.

water vapour $\left(\mathrm{H}_{2} \mathrm{O}\right)$ analyser (LI-7000, Li-Cor, Inc.) and an off-axis integrated cavity methane tuneable diode laser (PMT-200, Los Gatos Res., Inc.). Hydrogen sulphide emissions were estimated combining collocated methane emission and ambient air Total Reduced Sulphur measurements.

In 2009 measurements were used in order to obtain good spatial coverage of the large (15 ha) landfill area. Concentration and anemometer data were collected at a frequency of $10 \mathrm{~Hz}$ on a computer using RS232 data transfer protocol. The fluxes were calculated on-line as 15-minute averages. The software included coordinate rotation, decoding of signals using block averaging, removal of time shifts between the signals from the anemometer and each gas analyser, and the correction for high-frequency flux loss. Air and soil temperatures, air humidity, air pressure, net radiation and PAR radiation were measured to support data analysis.

The source areas of micrometeorological flux observations extend several hundreds of metres upwind from the mast. The source area depends on the measurement height, roughness length, wind speed, friction velocity, and atmospheric stability. In data analysis only good 
quality data based on turbulence and source area characteristics were included. The total emission from the landfill was calculated from the average emissions per unit area according to the surface cover types. The total emission from the landfill is the sum of subareas which were multiplied by its respective emission factor to cover the studied area.

\section{Methane reduction and other benefits}

According to measurements landfill gas generation was approximately $600 \mathrm{~m}^{3} / \mathrm{h}$, of which approximately $50 \%$ was methane. Moreover hydrogen sulphide $\left(\mathrm{H}_{2} \mathrm{~S}\right)$ generation was approximately $3,000 \mathrm{~g} / \mathrm{h}$. Before implementing any emission reducing measures the landfill gas recovery rate was approximately $50 \%$. As a result of optimized landfill gas recovery, the recovery rate was increased to up to $90 \%$. Hydrogen sulphide emissions were reduced by $95 \%$ (from $1,200-1,400 \mathrm{~g} / \mathrm{h}$ down to $20-90 \mathrm{~g} / \mathrm{h}$ ). The increased recovery rate is equivalent to approximately $1 \mathrm{MW}$ of additional energy, which is used for heat and power production on industrial scale. Moreover odour in the local neighbourhood was minimized.

\section{Costs}

The total investment for such an undertaking to measure landfill gas emissions $\left(\mathrm{CH}_{4}, \mathrm{CO}_{2}, \mathrm{H}_{2} \mathrm{~S}\right)$ and to optimize operation of landfill gas recovery are approximately 40-70 thousand Euro depending on length of monitoring and optimisation period.

Assuming a first order exponential decay of the amount of methane emitted from the landfill site over 20 years, the average amount of methane emitted is $554,478 \mathrm{Nm} 3 / \mathrm{yr}$. This reflects a total reduction in methane emissions of 118 ton/yr.

\section{Contact information}

Contact person:

Kai Sormunen,

Ramboll Finland Ltd

Tuomas Laurila,

Finnish Meteorological

Institute

Phone number:

Kai Sormunen

+ 358405127944

Tuomas Laurila

+358503671305

E-mail:

kai.sormunen@ramboll.fi

mailto:

tuomas.laurila@fmi.fi
Annualised costs were calculated to be $18,879 € / y$ r. Based on the assumptions presented in section 3 , and figures in 4.8 , the cost effectiveness of the micrometeorological methods and associated optimisation procedures, as a means to reducing methane emissions, is $120 € /$ ton $\mathrm{CH} 4$.

\section{Barriers and difficulties}

It is possible that landfill gas recovery has to be improved by additional landfill gas recovery wells, which may add total cost. Moreover damages in landfill gas wells and other structures may cause additional costs. In the particular landfill site landfill gas management was improved by more efficient operation of landfill gas recovery plant to optimize suction pressure in certain (emission) areas and landfill cover was sealed by surplus soils, thus higher investments were avoided. 


\subsection{Using landfill gas with low methane content to a further extent with an stirling engine}

Plant: Yggeset landfill

Location: Asker Community, Norway

Start-up year: Waste disposal since 1940's the stirling engine was

installed 2013

\section{Technical description}

The Yggeset land fill consist of about 430,000 tonnes of waste and is expected to theoretically produce about 1,400 tonnes of methane during its lifetime. In order to prevent this from reaching the atmosphere and contribute to global warming the landfill is covered by a modern gas collecting system put into operation in 2011. The system consists of 4,000 meter gas pipes and 23 gas wells were land fill gas is extracted. In order to have a god control of the landfill a monitoring system measures gas production, methane content, vaporization amongst other parameters. The gas generated is sent to a combustion system with five stirling engines.

The starter engine uses liquefied petroleum gas (LPG) before the stirling engine reaches a sufficiently high temperature so as to be running on landfill gas. According to the supplier the electrical efficiency is about $25 \%$, including usage off excess heat the total efficiency can reach 95\%. At Yggeset the electricity is used for heating buildings at the waste disposal facility and any overproduction is distributed out to the grid. Excess heat is in wintertime used to melt ice and snow and during summer mostly just cooled away. About $40 \%$ of the heat is used effectively. In total the energy content in the gas during 2012-2013 was estimated to 1,145 MWh.

Methane could be burnt in a flare or in a conventional gas engine with equal reduction of methane emissions as in a stirling engine. The benefits of a stirling engine over a conventional gas engine is above all a better resistance to the crude gas and a tolerance for lower methane content in the gas. The stirling engine is though more expensive in investment.

\section{Methane reductions and other benefits}

During the period of September 2012 to September 2013 approximately $293,000 \mathrm{Nm}^{3}$ landfill gas was generated with in average $38 \%$ methane content. This result in a methane emission reduction of 90 tonnes $\left(111,000 \mathrm{Nm}^{3}\right.$ with density $\left.0.8 \mathrm{~kg} / \mathrm{Nm}^{3}\right)$ per year.

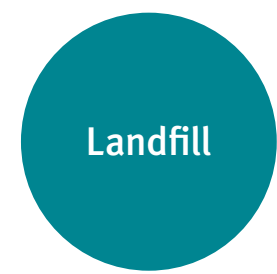

Short facts

Yggeset waste disposal is a medium-sized landfill with an average gas production compared to other Norwegian landfills. The quality and amount of gas varies over time and the landfill has passed its peak production which makes it more challenging to utilize the gas. For many years the gas was simply burnt in a flare. But in 2012 the Municipality voted the gas should be used for heat and power production in a stirling engine.

Why a methane abatement measure: The stirling engine at Yggeset is a good example of how to use conventional technique in a relatively new application so as to utilize the landfill gas to a further extent.

Calculated yearly methane reduction: The methane reduction during sept 2012 to sept 2013 was calculated to about 90 tonnes of methane. The methane production declines every year and so will the methane reducing effect. 


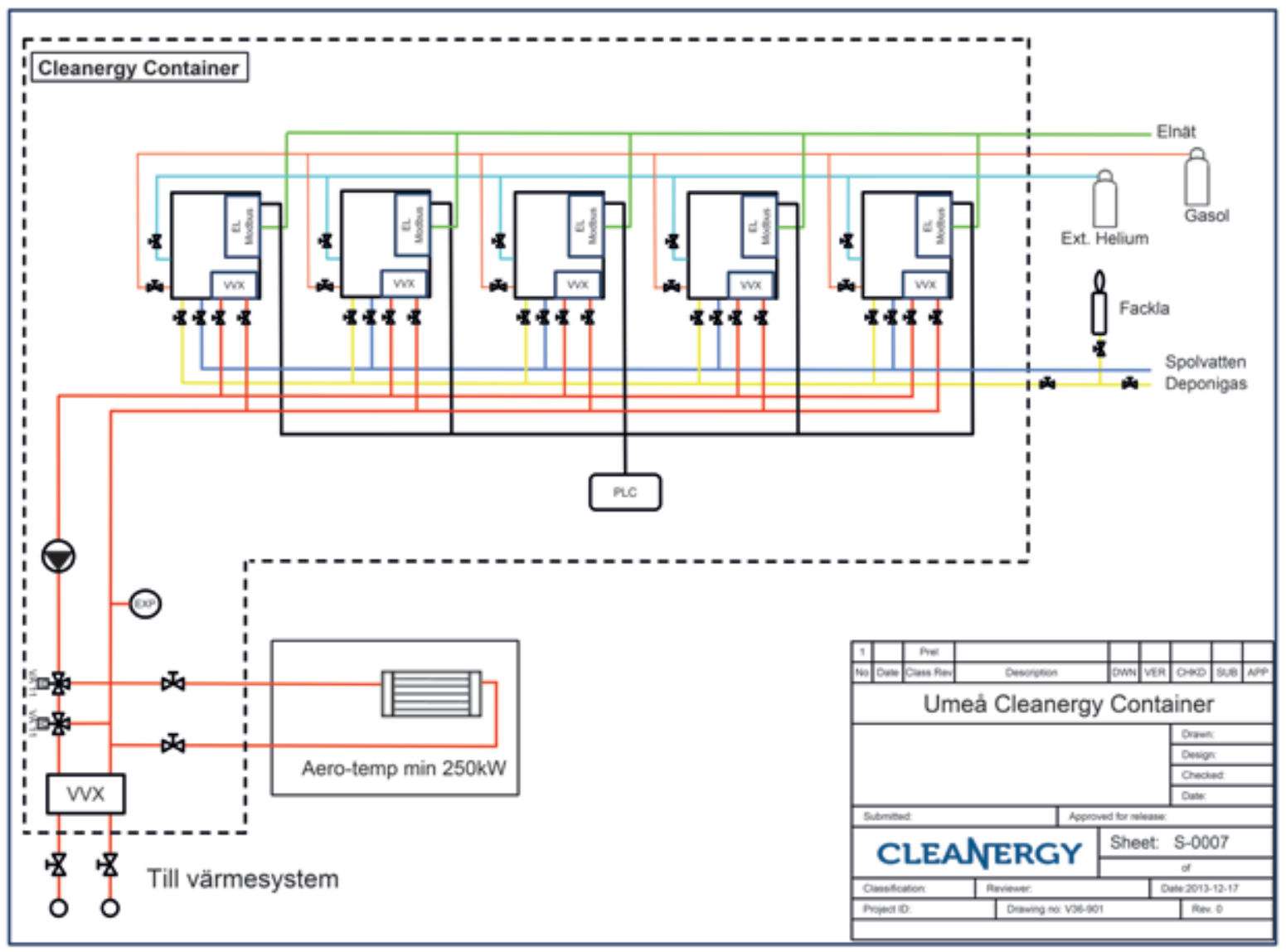

Figure 19 Overview of a system (not Yggeset) with five stirling engines, cooling/heating system and power generating unit (Cleanergy 2013).

Besides the direct reduction of methane emissions from the landfill less fossil fuel is needed to run the machines used for snow removal. Land fill gas also substitute other primer energy (Nordic power mix) previously used for heating.

The landfill had been calculated to continue producing gas during another 25 years. The methane content in the gas will decrease during the productive lifetime of the landfill. The calculated total amount of usable methane is estimated to be around 1,000-1,500 tonnes (less than $2 \mathrm{MNm}^{3}$ ).

\section{Costs}

The project budget was set to $557 \mathrm{t}$ Euro (4.7 MNOK) and included the investment of the complete gas engine system shown in .

Maintenance cost is by the supplier said to be between $1,700-3,400$ Euro per engine and year which results in a total maintenance cost of 8,500-17,000 Euro per year for Yggeset. Operating costs is still to be determined since the plant has only been operating for about 6 months. 
The investment divided with the total estimated reduction of methane results in the key figure of $0.56-0.37$ Euro per reduced $\mathrm{kg}$ of methane calculated as an average during the hole lifetime.

\section{Barriers and difficulties}

Since the plant has only been in operation for a few months problems and difficulties are still to be reviled.

One barrier for implementing this technique is the higher investment for stirling engines comparing to conventional gas engines. On the other hand the stirling have other advantages listed below that can justify a higher investment cost.

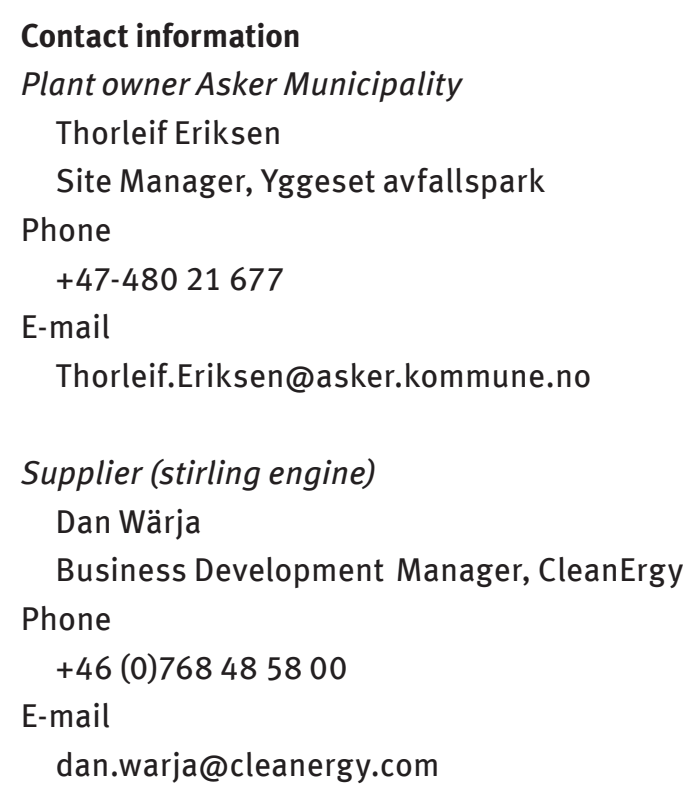




\subsection{Thermal hydrolyses of sludge for anaerobic digestion}

\section{Short facts}

The Fredericia waste water treatment plant (WWTP) is owned by the Municipality of Frederica and has a load of about 350,000 pe. Due to limitation of digestion tank volume they used to only be able to digest the primary sludge. By implementing a thermal hydrolyses process, (THP), they now digest all the sludge and have thus increased the biogas production by more than $100 \%$.

In the thermal hydrolyses process the sludge is exposed to high temperature and pressure resulting in an increased degree of degradation and thereby in creased biogas production. With a greater methane yield in the biogas process less methane is thus emitted from the digested sludge. This method can be used at all kinds of anaerobic digestion plants, digestion of sludge, organic waste, manure and codigestion plants.
Plant: Fredericia Spildevand A/S

Location: Fredericia, Denmark

Start-up year: Thermal hydrolysis in 2001

\section{Technical description}

The Frederica WWTP serves a residential population of about 90,000 equivalent peak load of about 350,000 pe. The non-domestic input comprises wastewater from a fertilizer factory, dairies, breweries, refineries (for both mineral and edible oils) and food industries. The sludge treatment is designed for 8,000 tonnes dry substance per year and currently about 5,000 tonnes dry substance per year are being treated.

Before the thermal hydrolysis only the sludge from the anoxic primary stage was digested and then dewatered. The sludge from the secondary treatment was not digested but only dewatered. This left a sloppy and smelly sludge cake that had to be disposed at landfill at a high cost.

After installation of the thermal hydrolyses process both primary and secondary sludge are treated and digested. The dewatered digested sludge are now delivered to a site where they are co-composted with greenwaste. Farmers are then paid to collect and apply the compost.

\section{Thermal hydrolyses}

The thermal hydrolysis process at Frederica WWTP was retrofitted in 2001 as a turnkey contract with Cambi. The plant was fitted in between an existing service building and the digester. The wastewater (and hence the sludge) has a high chloride content $(8,000 \mathrm{mg}$ $\mathrm{Cl} / \mathrm{l})$. This required that the thermal hydrolysis plant be manufactured in high-grade duplex stainless steel.

First the sludge from the primary clarification and the secondary treatment are combined and thickened to $18 \%$ dry substance content with a centrifuge. The thickened sludge is then pumped to a pulper tank where it is heated with waste steam from the thermal hydrolysis reactors to about $75-90^{\circ} \mathrm{C}$. From the pulper the sludge moves under steam pressure to one of two $12 \mathrm{~m}^{3}$ reactors. When one reactor is filled it is heated to $160^{\circ} \mathrm{C}$ using steam. The content is held in one reactor for about 0.5 hour. The sludge is then pushed by steam 
pressure to a flash tank. In the flash tank the pressure is released via the pulper and used to move the sludge to a reactor.

The solid content of the hydrolysed sludge is less than that of the thickened feed sludge because of dilution with condensed steam and solubilisation of organic matter. A controlled amount of extra water is added to reduce sludge to $10 \%$ dry substance to ease flow through the sludge cooler heat exchanger. The temperature of the sludge is dropped to about $40-45^{\circ} \mathrm{C}$ and the digester feed pump operates continuously feeding hot sterilized sludge to the two mesophilic digesters alternately, $0.5 \mathrm{~h}$ each. There are two digesters, 2,000 $\mathrm{m}^{3}$ each with conical bottoms. The digesters operate at $39.5^{\circ} \mathrm{C}$.

\section{Digested sludge}

The plant produces about 4,000 tonnes dry substance of digested sludge each year. The sludge is dewatered and delivered to a compost site. The composter requires that the cake does not exceed $30 \%$ dry substance. The quantity of the cake produced is now only $57 \%$ of the former volume (before thermal hydrolysis). Farmers are then using the compost which leads to returning the nutrients to the agricultural land. Before thermal hydrolysis the sludge cake was disposed at landfill.

\section{Biogas production and use}

The total biogas production with thermal hydrolysis is about 3200 $000 \mathrm{Nm}^{3}$ per year with a methane content of $63 \% .50 \%$ of the biogas is used for steam raising of the process and the other $50 \%$ is used for CHP (combined heat and power) as showned in table 10.

\begin{tabular}{lccc}
\hline & $\begin{array}{c}\text { Produced biogas } \\
\left(\mathrm{Nm}^{3} / \mathbf{y}\right)\end{array}$ & $\begin{array}{c}\text { Methane content } \\
(\%)\end{array}$ & $\begin{array}{c}\text { Produced methane } \\
\left(\mathrm{Nm}^{3} \mathrm{CH}_{4} / \mathbf{y}\right)\end{array}$ \\
\hline Before & $1,560,740$ & $65 \%$ & $1,008,238$ \\
With thermal hydrolysis & $3,188,528$ & $63 \%$ & $2,008,773$ \\
\hline Difference & $1,627,788$ & & $1,000,535$ \\
\hline
\end{tabular}

\section{Usage of water}

For the process approximately $0.2 \mathrm{~m}^{3}$ water (steam) is used per 1 tonne thickened sludge. The tap water is very expensive in Denmark and therefore all of the water used within the thermal hydrolysis process is recovered from the final effluent using a sequence of sand filter, carbon filter, ultra-filtration and reverse osmosis.

\author{
Short facts \\ Why a methane abatement \\ measure: Good example \\ of thermal hydrolyses \\ to increase biogas \\ production and decrease \\ methane potential in the \\ digested sludge.
}

Yearly methane reduction: The methane reduction from the plant is mainly due to:

- Reduction of the methane potential in the dewatered sludge

Table 10 Biogas production and use 


\section{Methane reductions}

The methane reduction from the plant is mainly due to:

- Reduction of the methane potential in the dewatered sludge

The thermal hydrolysis process increase the biogas production with about $100 \%$ but the high temperatures requires about $50 \%$ of the produced gas is used in the process. This means that all increased gas is used and the net methane reduction from the process is mainly due to a more decomposed sludge and therefore lower leakages. These amounts of reduced methane are not possible to quantify without further measurements.

\section{Costs}

Investment about 2.2 million Euro in 2001.

\section{Contact information}

Contact person:

Annemarie Gotfredsen, driftsleder at Fredericia Spildevand A/S

Phone number:

+ 4541892325

E-mail:

ag@fredericiaspildevand.dk 


\subsection{Sealed tanks for digested sludge}

Plant: Rya wastewater treatment plant (WWTP), operated by Gryaab AB

Location: Gothenburg, Sweden

Start-up year: 2013

\section{Technical description}

The Rya WWTP in Gothenburg has reduced methane emissions by retrofitting a sludge storage silo as a digester with variable sludge volume. In this way the methane is captured whilst maintaining the possibility to buffer up to $3,500 \mathrm{~m}^{3}$ of digested sludge.

\section{Emission measurements}

Gryaab AB, the operator of The Rya WWTP in Gothenburg, performed emission measurements in 2009 as a part of the organization's continuous work with mapping of the plant's Carbon Footprint. The methane measurements were performed with FID instrument (flame ionization detector) combined with collection of samples for analysis by GC (gas chromatography). The measurements indicated that $34 \%$ of the identified methane emissions from the wastewater treatment plant were derived from a large digested sludge silo which was open to the atmosphere.

\section{Capture of the emitted methane}

It was decided that the open silo should be sealed in order amend the emission problem. The original objective was to install a gas tight cover on the existing silo but this solution turned out to be costly and complicated due to concerns about the stability of the existing structure to withstand the weight of a cover and the increased gas pressure. The final solution was the placement of a custom built $4,000 \mathrm{~m}^{3}$ stainless steel tank, which was constructed on site, within the existing silo. The 22 meter high, 80 tonnes steel tank was lifted into place in less than an hour with a 600 tonnes crane.

\section{Preparations}

In order to carry out the project, a temporary operational strategy was required, where one the two existing digesters was modified to be operated as a sludge storage silo during the retrofitting. This meant that the remaining digester was highly loaded during this period. This strategy required new gas zone documentation and several risk analysis hade to be performed at different phases of the work.
Waste

water

treatment

\section{Short facts}

The Rya WWTP in Gothenburg has reduced methane emissions by retrofitting a sludge storage tank as a digester. Gryaab measures methane emissions as a part of the organization's continuous work with mapping of the plants Carbon Footprint. In 2009 the measurements indicated that about $34 \%$ of the methane emissions from the wastewater treatment plant originated from a large digested sludge storage silo. A decision was taken in 2010 to amend the problem. A sealed steel tank, placed inside the existing concrete silo was taken into operation in 2013.

Why a methane abatement measure:

Good example of an efficient action. The methane that was previously emitted is now captured and incorporated into the biogas production.

Yearly methane reduction:

- 81 tonnes by capturing previously emitted methane. 
Figure 20 A sealed silo is placed within the existing sludge-storage tank.

Photograph: Bo Enström, Gryaab 2013

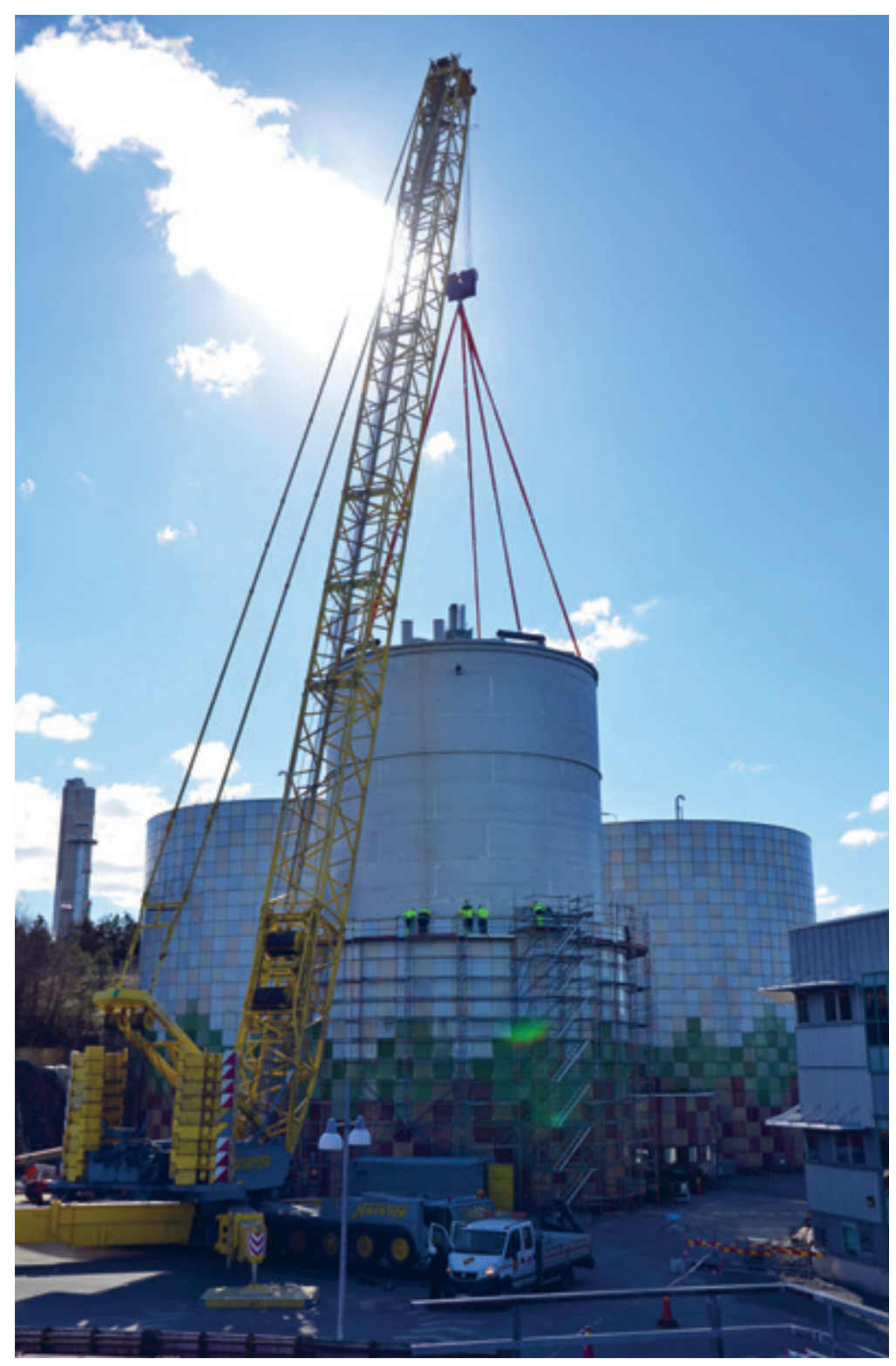

Positive side effects

The retrofitting yielded several positive effects in addition to the climate benefits. Occupational health and safety has improved significantly as three new emergency evacuation routes have been created on the exterior of the biogas plant. The biogas collection system has been upgraded to the latest standards for this type of facility. The capacity of the biogas collection system and the ability to flare off any unused biogas has also significantly increased. In addition, the original $200 \mathrm{~m}^{3}$ biogas buffer tank was replaced by a new $800 \mathrm{~m}^{3}$ tank. These improvements provide better stability within the whole gas collection and delivery system and result in more stable operation with fewer disturbances. 


\section{Methane reductions and other benefits}

Gryaab AB estimates that by retrofitting the sludge-storage silo with sealed tank methane emissions have been reduced by about 81 tonnes per year.

\section{Costs}

Investment cost was approximately 48 million SEK (about 470 million Euro).

The project also received 1.5 million SEK (about 14.8 million Euro) in subsidy from the Swedish Energy Agency.

The annualised cost for this investment is 497,896 euro/yr which represents a cost effectiveness of $6,146 € /$ ton $\mathrm{CH} 4$. No information provided on added operating costs

\section{Barriers and difficulties}

One of the major challenges was to keep the biogas plant in continuous operation during the project. This required constantly evaluating all risks associated with working in an environment with the presence of large amounts of potentially explosive biogas.

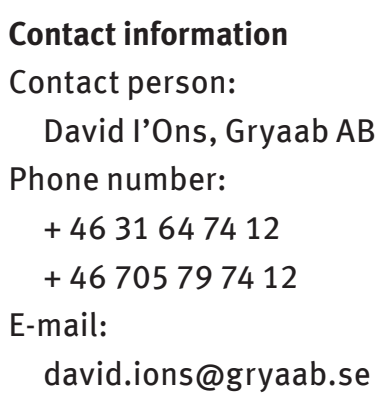




\subsection{Large scale anaerobic digestion and pre-treatment of organic waste from households and slaughter house waste}

\author{
Short facts \\ A plant for anaerobic \\ digestion of organic waste \\ from households. The \\ plant at Kungsängens gård \\ receives annually 3,000 \\ tonnes of slaughter house \\ waste and 25,000 tonnes \\ of organic waste from \\ households. The anaerobic \\ digestion plant produces \\ $28 \mathrm{GWh}$ biogas per year. \\ The biogas produced \\ at Kungsängens gård is \\ upgraded to a methane \\ content of minimum $97 \%$ \\ and it is used as vehicles \\ fuels for the public buses \\ in Uppsala.
}

Why a methane abatement measure: Good example of one of the first plants for anaerobic digestion of organic waste from households, the entire process from collection of waste to production of biogas used as vehicle fuel. Methane reduction through production of vehicle fuel replacing fossil fuel and also reduction of methane gas from alternative handling of organic waste.
Plant: Uppsala Biogas Plant

Location: Kungsängens gård, Uppsala, Sweden

Start-up year: 1996 with continuous development

The biogas plant is located at Kungsängens gård in Uppsala, Sweden. The plant produces biogas and biofertilizers from food waste from households and organic waste from food companies, such as slaughterhouses. The plant receives 25,000 tonnes organic waste from households every year as well as 3,000 tonnes slaughter house waste. The biogas is used as fuel in buses and cars the biofertilizers are used at the agricultural fields in Uppsala which certifies a natural and local recycling of nutrients.

Information and collection of organic waste from households Uppsala Water leads an intensive work with information campaigns directed towards the public in Uppsala in order to secure the supply of organic waste. The information campaigns takes place in people's homes, in schools and in kindergartens and the public are asked to sort the organic household waste.

\section{Technical description}

\section{Reception}

At the plant there are two receiving bays, one for the household food waste, which comes in bags and one for food waste that is not packaged, such as slaughterhouse waste. A special machine tears the bags and separates them from the food waste. The bags are compressed and sent for incineration. With the help of large screws the food waste goes into the facility where it is mixed with the unpackaged food waste. The mixed food waste is diluted with water in a pulper in order to enable it to be pumped on to large buffer tanks, where it is stored until further processing.

\section{Decomposition}

In the buffer tanks decomposition takes place where the organic waste is milled to pieces in a dispersing. After milling the material is screened in a sieve gauze in order to separate residual contaminants, such as plastic. The residues trapped in the sieve gauze is thereupon transported to a waste treatment plant for composting or to an 


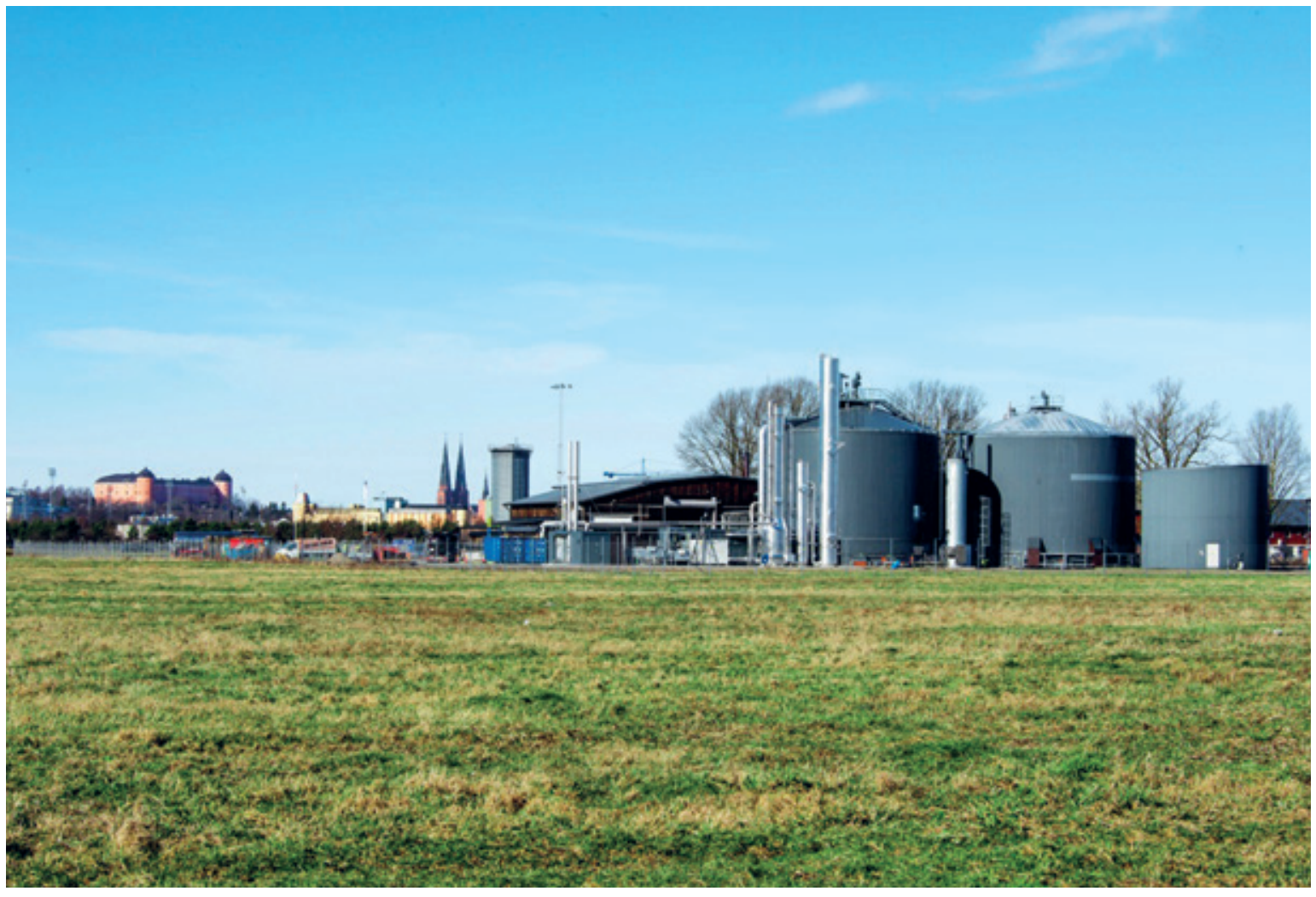

Figure 21 Anaerobic digestion plant in Uppsala, Sweden.

incinerator. After being decomposed the organic waste is stored in a buffer tank in order to enable a smooth entry to the pasteurized tanks.

\section{Sanitisation}

After the decomposition the organic waste is distributed to three pasteurized tanks ( $8 \mathrm{~m} 3$ each) which run alternately so that there is an even outflow. In each tank the material is heated to $70^{\circ} \mathrm{C}$ for at least an hour in order to secure sanitation and the removal of infectious microorganisms. To get the right temperature to the next step the material passes a heat exchanger where the excess heat is recovered.

\section{Digestion}

At the plant there are two anaerobic digesters (2,300 m3 each). In the anaerobic digesters there are a continuous input and stirring of the decomposed organic matter. Through this process different types of microorganisms degrade organic materials in the absence of oxygen at $52{ }^{\circ} \mathrm{C}$ for approximately 30 days in a process referred to as a continuous anaerobic thermophilic process. The anaerobic digestion produces biogas and biofertilizers. The biogas consists of $65 \%$ methane and $35 \%$ carbon dioxide.

\section{Short facts}

Methane reduction:

- Approximately reduction of 3 tonnes of methane from replacement of diesel.

- Reduced methane potential in digested sludge for fertilizers compared to e.g. composting of organic waste (not quantified) 


\section{Gas system}

The majority of the biogas production is used as vehicle fuel. For the gas to be used as vehicle fuel it must be purified of carbon dioxide and reach a methane concentration of minimum $97 \%$. From the spring of 2014 there gas is upgraded in a new water scrubbing system before delivered to filling station. The water scrubbing uses water in order to separate carbon dioxide from the gas and deliver a gas with substantially higher content. The upgraded gas is supplied to filling stations for buses and cars. A small portion of the biogas is used for electricity and heat production in the plants. In case of disturbances the gas is combusted in a flare in order to secure that no emissions of methane is released to the atmosphere.

\section{Production of biofertilizers}

The organic material remaining in the digester after the gas production is known as digestate, which can be used as biofertilizer. The digestate is pumped from the digester to a tank, wherefrom it is transported to farmers around Uppsala. Digestate is a full fertilizer containing available nutrients, such as nitrogen and phosphorus. It also supplies valuable humus. The biofertilizer is authorized under the certification rules for digestate from SP Technical Research Institute SPCR 120 and bears the mark "certified recycling” (Uppsala Vatten, 2011).

\section{Methane reductions and other benefits}

In 2013 the plant produced about 4.6 million Nm3 biogas/year, about $28.4 \mathrm{GWh}$ of which $89 \%$ was upgraded and used as vehicle fuel, $9 \%$ for internal heating and $2 \%$ combusted in the torch.

The methane reduction from the plant is mainly due to two factors:

- Replacement of fossil fuel to vehicles (diesel for buses in Uppsala)

- Reduction of the methane emissions from organic waste compared to compost handling (not quantified)

\section{Replacement of fossil fuel}

The total amount of reduced methane from replacement of fossil fuels is approximated to about 3 tonnes methane per year. The calculations are based on emission factors for production and utilisation of diesel for buses. The key factors for emissions used are:

Production and utilisation of diesel in bus $0.034 \mathrm{gCH}_{4} / \mathrm{MJ}^{19}$

\section{Costs}

The overall total investment costs for the plant described above exceeds 150 million SEK a number that includes a lot of development costs. As pioneers and one of the first to implement the technology 
with biogas production from organic household waste the plant has been rebuilt and improved in many different stages.

Based on current knowledge an estimated investment for a similar plant projected and built today would be about 150-200 million SEK (about 15-20 million Euro). That would include a plant with pretreatment, digestion and upgrading.

The operating costs, excluding costs for collection of substrates, for a similar plant is estimated to about 15-20 million SEK per year (about 1.5-2 million Euro).

Annualised investment cost for the plant was 2,087,860 euro. Based on the assumptions presented in section 3 , and figures in 4.12 , the cost effectiveness of the Uppsala plant, as a means to reducing methane emissions, is $684,720 € /$ ton $\mathrm{CH} 4$.

\title{
Barriers and difficulties
}

Uppsala Water has over the years encountered and overcame a lot of difficulties. For example there have been problems to get the reception process to function properly, there have also been operational difficulties with the fermentation process and there have been incidents leading up to gas explosions. A lot of knowledge has been gained throughout the process and over the years the plant has been a case study for many young technicians.

When asked to give advice for someone interested in a similar investment Michael Persson, Waste Manager at Uppsala Water and Waste emphasizes on the need to ensure enough raw materials. Persson suggests that an annual collection of about 20,000 tonnes organic waste is necessary in order to get a return of the investment (Uppsala Vatten 2011); Persson, M. (2014).

\author{
Contact information \\ Contact person: \\ Michael Persson, \\ Uppsala Water and Waste \\ Phone number: \\ + 46187279361 \\ E-mail: \\ michael.persson@ \\ uppsalavatten.se
}




\subsection{Voluntary agreement for anaerobic digestion and gas upgrading plants}

\section{Short facts}

Avfall Sverige (Swedish

Waste Management and

Recycling Association)

has set up a voluntary agreement for control of methane emissions from biogas and upgrading plants. Starting in the year 2007 the Voluntary Agreement was initiated with the aim of establishing a systematic approach to quantification and minimization of methane emissions. There are three actions performed in the voluntary agreement, 1) Inventory of systematic emissions,

2) Leak detection and

3) Emission measurements and calculations.
Plant: Several biogas and upgrading plants in Sweden

Location: Several locations in Sweden

Start-up year: 2007

\section{Technical description}

Starting in the year 2007 the Voluntary Agreement was initiated by Avfall Sverige (Swedish Waste Management and Recycling Association) with the aim of establishing a systematic approach to quantification and minimization of methane emissions from biogas and upgrading plants. To date measurements and calculations have been performed at ca 20 individual biogas plants and ca 30 upgrading plants.

\section{System boundaries}

The Voluntary Agreement includes control and measurement of methane emissions from biogas and upgrading plants within:

- parts of the plant of which the plant owner has control over and

- parts connected to production or cleaning/upgrading of biogas.

Thus methane emissions that arise from utilization of biogas or digestate are not included.

The Voluntary Agreement system starts where the substrate is delivered to the biogas plant. If the plant is a waste water treatment plant the system only includes the parts that are directly related to biogas production and in that case the system of Voluntary Agreement begins when the sewage sludge enters the digester or at the point where the sewage sludge is treated before the digestion (in e.g. mills or centrifuges). Thereupon all parts of the biogas production plant are included in the context of the agreement; from storage of the substrate, pre-treatment processes, mixing, digestion, post-digestion and storage of digestate at the plant. The system covers stages up until the point at which the digestate is transported from the plant by truck or in a pipeline. For produced biogas, the system covers up until the point at which the gas is transferred to a boiler, engine, a turbine or an upgrading plant. For the upgrading plants, the Voluntary Agreement starts when the gas enters the building containing the upgrading equipment and ends when the gas is cleaned, dried or odorized. Methane emissions during transport of the upgraded biogas, 
compression, propane addition, gas storage or emissions at filling stations are not included.

\section{Methodology}

There are three actions performed in the voluntary agreement:

- Inventory of systematic emissions

- Leak detection by the staff of the AD and/or biogas upgrading plants

- Emission measurements and calculations

\section{Inventory of systematic emissions}

If the plant is participating in the Voluntary Agreement the plant's staff are required to make an inventory of systematic emissions. These shall be marked on a map or plan of the plant, which is then reviewed together with a measurement consultant. To be able to do this, staff needs a thorough knowledge of the plant. At least one of the staff members participating in the inventory shall have taken the course on the Voluntary Agreement regularly organized by Avfall Sverige. A classification plan can be helpful in making the inventory of systematic emissions, since it describes where explosive gas mixtures can occur and thus where systematic emissions may be expected.

From experience the following points of emission can be found at biogas plants and sewage sludge digesting plants:

- Central ventilation (whole or part of the plant, mechanical or natural ventilation)

- Ventilated tanks (mixing tanks o, process water tanks, digestate tanks)

- Digester (systematic emission at overflows and/or leaks collected in building ventilation on top of the tank)

- Dewatering systems (usually ventilated)

- Digested storage (liquid/solid fraction stored on site, note system boundaries)

- Instruments for gas analysis (rotameter readings)

From experience the following points of emission can be found at biogas upgrading plants:

- Off-gas $\left(\mathrm{CO}_{2}\right.$ release)

- Central ventilation (whole or part of the plant, mechanical or natural ventilation)

- Instruments for gas analysis (Rotameter readings)

\section{Short facts}

Why a methane abatement measure: To date measurements and calculations have been performed at about 20 individual biogas plants and about 30 upgrading plants. The available results show that the majority of plants have total methane emissions of less than $2 \%$ of the methane produced at the specific plant. During the first three years a few outliers were identified with methane emissions of up to $10 \%$. In these cases measures have been taken already and these plants now have much lower emissions during the second round of measurements (2010 and onwards).

Yearly methane reduction: Not applicable since there are several different measures within the same programe. 


\section{Leak detection}

Systematic leak detection shall be performed by the staff of the plant throughout the entire plant with a leak detection instrument and leak detection spray. The instrument is moved along potential leakage points, both at a distance from the equipment, and very close to it. Thereupon detected readings are noted in a protocol. If possible, the exact source of the leakage shall be determined and noted, and if possible the leakage shall be addressed and stopped immediately. A checklist shall be used as a protocol for the leak detection and it needs to be archived for inspection. Leak detection shall be performed at least once a year, but it is strongly recommended that it is performed on a monthly basis. Avfall Sverige advises the plants to use an external resource from time to time to avoid "domestic blindness".

\section{Emission measurements, calculations and set of targets}

Every third year an external measurement consultant visits the plants and makes measurements during normal production conditions. Measurements shall be done during a longer time (as a general rule one hour at each point) and data shall be logged. Avfall Sverige advises that the measurement shall continue until a stable signal is detected or a stable pattern is identified, this is important since the resulting methane emissions are extrapolated to a yearly basis from this measurement. Methane slip in one point is related to the total flow of methane in the plant by calculation. Measurements are typically made in ventilation systems and Off-gas release. European and international measurement standard methods are being used for these measurements when applicable. Many measurement and calculation methods have had to be adopted to the varying circumstances found at plants, and these experiences have since been gathered in a Methane Measurements Handbook. The results from the emission measurements are used to calculate annual emissions and with these results at hand the plant has to set specific targets for their mass emissions and show that they take measures to reach these set targets.

\section{Methane reductions and other benefits}

To date measurements and calculations have been performed at ca 20 individual biogas plants and ca 30 upgrading plants. The available results show that the majority of plants have total methane emissions of less than $2 \%$ of the produced methane at the specific plant. A few outliers have been identified, especially during the first 3 years, within methane emissions of up to $10 \%$. In these cases measures have been taken already and these plants now have much lower emissions during the second round of measurements (2010 and onwards). 


\title{
Costs
}

Avfall Sverige administers the program, which is free and optional/ voluntary to join. Each plant pay for their own systematic work with inventory of systematic emissions, leak detection, emission measurements, calculations, set of targets and the systematic work to reach these set targets.

Cost effectiveness is difficult to quantify for the voluntary agreement for anaerobic digestion and gas upgrading plants due to the fact that technical measures as well as actual methane emission reduction varies considerably between the different members.

\section{Barriers and difficulties}

It is both a strength and a weakness that the program is voluntary. There is a risk some facilities does not participate although there would be useful for them as an emission reduction measure. On the other hand the facilities actually participating have entered of free will and are hopefully motivated to take action.

Technically there is a difficulty in measuring methane emissions and accurate measurements can be quite expensive if a certified firm and advanced instruments are used. Techniques and methods for measuring of methane emissions is still under developing and for example measuring of methane emissions from larger surfaces such as digestate storages is developed by SP. It can also be hard to determine where to place measuring points and in some cases it is also hard to actually do the drilling and make the point of measurement dense.

\author{
Contact information \\ Contact person: \\ Adviser Biological \\ Treatment, Avfall Sverige \\ Phone number: \\ + $46(0) 40356623$ \\ For further reading se \\ www.avfallsverige.se
}




\subsection{Hydrocarbon blanketing to eliminate VOC emissions from cargo tanks at FPSOs}

\section{Short facts}

Inert gas blanketing is commonly used by Floating Production Storage and Offloading units (FPSOs) for crude storage tanks. A variable mix of inert gas and hydrocarbon (HC) vapours (with HC vapour concentrations up to $70 \%$ ) is then vented to the atmosphere during loading through dedicated deck vents, resulting in significant VOC emissions to the atmosphere (including methane and non-methane VOCs (nmVOC).

Blanketing of crude storage tanks with $\mathrm{HC}$ gas can enable recovery of blanket gas during loading (often requiring additional compression). The recovered gas is routed back to the process stream, and under normal operation, VOC emissions from the tanks are eliminated.

HC blanketing systems have successfully been installed on a number of Norwegian FPSOs and have resulted in significant avoided emissions of methane and nmVOC from crude oil storage.
Plant: Multiple, see references under "Contact information"

Location: North Sea, Norwegian continental shelf

Start-up year: First installation in 1999 by Statoil (Åsgard A)

\section{Technical description}

\section{Inert gas blanketing - base case system description}

Upon discharge of crude storage tanks on a FPSO, a blanket medium is required to displace the discharged volume and maintain a slight overpressure. Inert gas is typically used to replace the tank atmosphere and prevent air being drawn in and potentially forming explosive mixtures with HC vapors in the tanks. "Inert gas" is the common term for the flue gas that is produced by burning fuel oil or diesel in boilers or inert gas generators, and consists mainly of $\mathrm{CO}_{2}$ and $\mathrm{N}_{2}$.

During both offloading and loading $\mathrm{HC}$ gases will continuously be released from the oil in the storage tanks and mix with the inert gas. This can result in a gas mixture of up to $80 \% \mathrm{HC}$ gas by volume towards the end of a loading cycle. During production of crude, this mixture (with variable $\mathrm{HC}$ content) is vented to the atmosphere via carefully located deck vents. Venting results in significant emissions of hydrocarbons to the atmosphere, typically in the range of hundreds of tonnes of methane and thousands of tonnes of nmVOC per year. Venting can also lead to formation of hydrocarbon clouds during calm weather. This sometimes result in a gas alarm triggering an Emergency Shut Down (ESD) with an associated loss of production.

\section{HC blanketing system}

The purpose of the $\mathrm{HC}$ blanketing system is to replace the use of inert gas with pure hydrocarbon gas as the main blanket gas in the storage tanks and to recover the off gas. The principle of using hydrocarbon gas as blanket gas is equal to the existing inert gas system. Both inert gas and $\mathrm{HC}$ gas are used to prevent low pressure and intrusion of oxygen into the storage tank atmosphere. The advantage of the $\mathrm{HC}$ blanketing system is a pure hydrocarbon atmosphere, which results in a less problematic approach regarding recovery of displaced gas from the storage tanks during loading. The HC blanket gas also reduces the corrosion problems in the storage tanks and in the tank vent system as it contains less corrosive components. The 


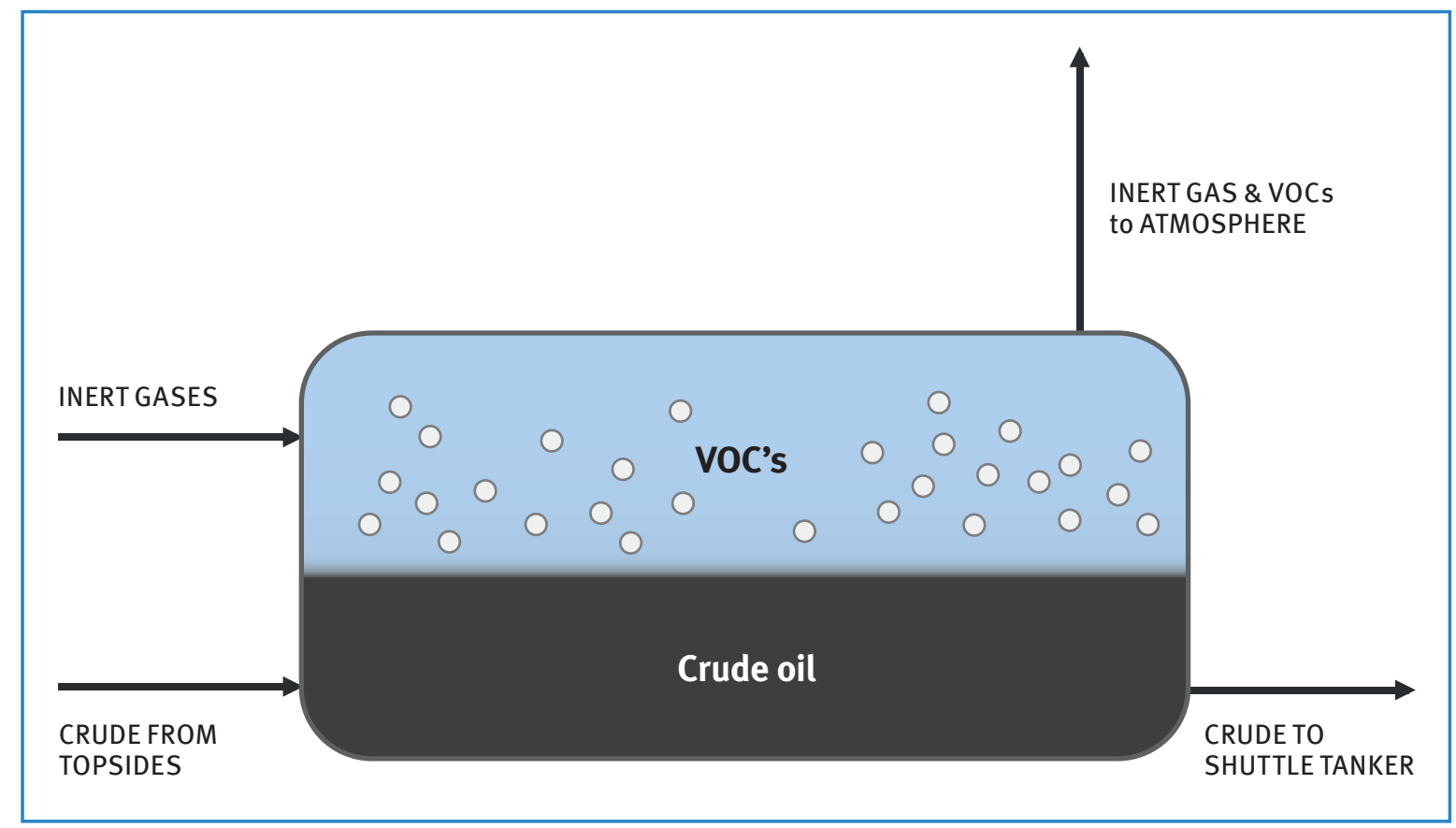

Figure 22 Inert gas blanketing

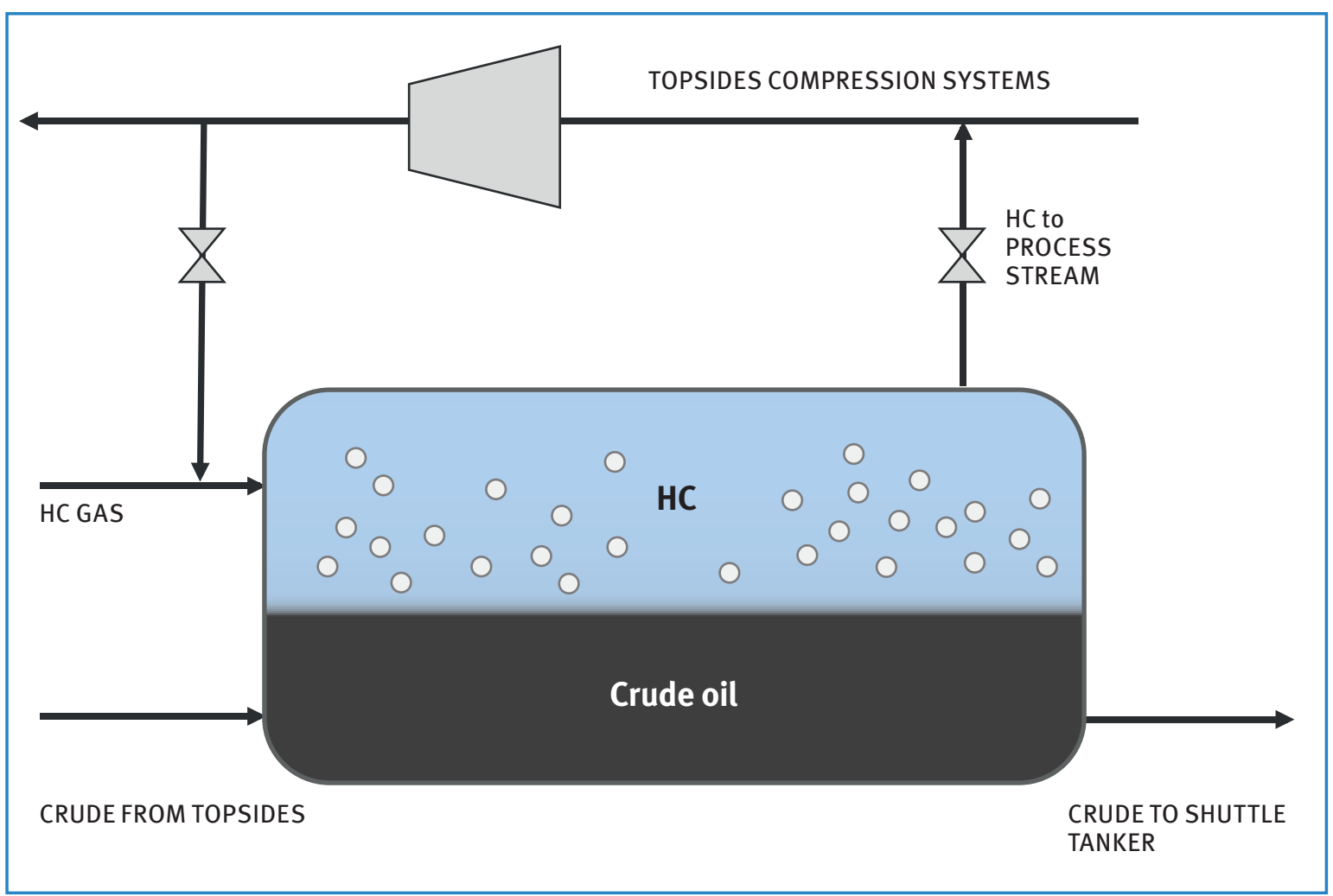

Figure 23 HC blanketing 
existing vent or inert gas header may be utilized for the $\mathrm{HC}$ blanket gas supply and recovery system. Alternatively, a new set may be installed to increase flexibility.

The extra equipment required for the $\mathrm{HC}$ blanketing system as compared to the inert gas blanketing system comprise the following:

- Compressor/blower/ejector (case specific)

- Heat exchanger/pressure vessel (case specific)

- Structural steel

- Piping and valves

- Instrumentation/controls

- Additional fire/gas monitoring, deluge systems and drain lines

The two normal operating modes of the $\mathrm{HC}$ blanketing system are:

1. Normal oil production without oil export. Requires treatment of surplus gas. The HC Blanket Gas Skid recovers displaced gas from the storage tanks back to the process plant.

2. Crude oil offloading exceeds oil production. Need for $\mathrm{HC}$ blanket gas supply. HC blanket gas from the process plant is being supplied to the storage tanks.

The utilized $\mathrm{HC}$ blanket gas should come from a source delivering gas close to equilibrium with the oil and preferably at low pressure. This might reduce power consumption in the gas compressor train and reduce evaporation of the oil. It is also an advantage that the gas is recovered to the process were the pressure is low in order to save compression work in the recovery compressor. If the oil production is low, the gas flow from a single blanket gas source might be insufficient for blanket gas. Additional blanket gas may then be taken from another source (e.g. 1st stage separator gas outlet or the fuel gas system).

Using HC blanket gas instead of inert gas has been proven to be environmentally, economically and technically justifiable for a number of FPSOs operating on the Norwegian Continental Shelf, and this measure has eliminated VOC emissions from storage tanks during normal operation.

\section{Methane reductions and other benefits}

Use of a $\mathrm{HC}$ blanketing system provides both environmental and economic benefits compared to an inert gas blanketing system. Key benefits comprise the following: 
- Increased crude oil volume for sale. Use of hydrocarbon gas as blanketing medium reduces the evaporation of VOCs from the crude, resulting in a higher volume of crude that can be transferred to the shuttle tanker (and slightly higher vapor pressure).

- Increased gas volume for sale. Recovery of VOC from the storage tanks will lead to increased gas volumes for sale (or other uses).

- Reduced use of fuel to run the inert gas generator. With a HC blanketing system, use of the inert gas generator is limited to tank inspections, maintenance and upsets related to the VOC recovery system. If diesel-powered generators are used for producing inert gas, cost-savings can be significant (up to \$0.5 MM per year).

- Reduced risk of ESD during calm weather (loss of production).

- Reduced emissions of nmVOC, methane and $\mathrm{CO}_{2}$.

- Reduced maintenance due to less corrosive blanketing gas (in particular when diesel is used as fuel for the inert gas generator).

The combination of these benefits has made $\mathrm{HC}$ blanketing an interesting measure both from an environmental and an operational perspective.

The net reductions in methane and nmVOC emissions for a specific case are primarily determined by the factors affecting the VOC emission that would result from using inert gas blanketing:

- The production profile of crude oil and its composition

- The vapor pressure of the crude oil

- Loading arrangement to cargo tanks

- Temperature and pressure in cargo tanks

- Wave action (movement)

As a result, emission reductions are very case specific and will vary over time. As the emissions that would have resulted from using inert gas as blanketing medium are not measurable after installation of a $\mathrm{HC}$ blanketing system (process change), the avoided emissions of methane and nmVOC needs to be quantified though modelling ${ }^{20}$.

Tank cleaning for inspections and tripping of equipment would be associated with increased VOC emissions when using HC blanketing compared to an inert gas system due to venting of $100 \% \mathrm{HC}$ gas as opposed to gas with a lower HC content (30\%-80\%) for a limited period of time. This reduce some of the environmental benefits obtained during stable operations. Potential leakage points are also introduced (flanges etc.).

Based on simulations with DynaVap, emission reductions resulting from use of $\mathrm{HC}$ blanketing have been estimated for two types of crude
20 Different modelling approaches could be applied, from static equilibrium models to advanced Computational Fluid Dynamics (CFD) models. The main supplier of the $\mathrm{HC}$ blanketing systems installed in Norway have applied dynamic simulations with DynaVap for facility design and estimation of emission reductions. The program is used to calculate the amount and composition of gas emitted from the storage tanks during loading as an inert blanket gas or HC blanket gas is used. The amount of inert or $\mathrm{HC}$ blanket gas needed to maintain storage tank operation pressure during offloading is also calculated. The models for loading and offloading of the tank are programmed in Microsoft Excel Visual Basic. Thermodynamic calculations are performed in Hysys. This makes it possible to integrate the equilibrium model in an existing simulation of a process system (Wärtsilä Oil \& Gas Systems). 
Table 11 Summery of cases.

Table 12 Economic of different technical alternatives.

$21 \mathrm{HC}$ blanketing is sometimes combined with flare gas recovery (FGR), a case which is not considered in this document (FGR will increase costs and yield additional benefits). Potential cost savings related to painting of deck heads due to using a less corrosive blanketing gas are not considered. Installation of a $\mathrm{HC}$ blanketing system require space and add weight (40 tonnes for one concrete installation). This represent an opportunity cost which has not been quantified. Furthermore, added weight can reduce the crude storage capacity of the PFSO requiring higher frequency of offloading. with different vapor pressure in the table below (for a temperature of $60^{\circ} \mathrm{C}$ and a pressure of $108.33 \mathrm{kPa}$ in the cargo tanks):

\begin{tabular}{lcc}
\hline & Case 1: Low RVP & Case 2: High RVP \\
\hline Oil production: & $24,600 \mathrm{bbl} / \mathrm{day}$ & $24,600 \mathrm{bbl} / \mathrm{day}$ \\
Avoided methane emissions: & $90 \mathrm{t} / \mathrm{yr}$ & $220 \mathrm{t} / \mathrm{yr}$ \\
Avoided nmVOC emissions: & $1,065 \mathrm{t} / \mathrm{yr}$ & $2,571 \mathrm{t} / \mathrm{yr}$ \\
\hline
\end{tabular}

The lifetime of the reduction measure exceeds 10 years, and the annual benefits will be dictated by numerous factors and vary with the oil production rate.

\section{Costs}

For the purpose of this document, the typical costs of $\mathrm{HC}$ blanketing is compared to an alternative inert gas blanketing solution (base year 2011) $)^{21}$.

\begin{tabular}{|c|c|c|c|c|c|}
\hline & & \multicolumn{2}{|c|}{ INERT GAS BLANKETING } & \multicolumn{2}{|c|}{ HC BLANKETING } \\
\hline & & NOTE & COST & NOTE & COST \\
\hline \multirow{2}{*}{$\begin{array}{l}\times \\
\text { w } \\
\text { a } \\
\leq\end{array}$} & Inert gas generator & 2 generators & $\$ 800 \mathrm{k}$ & 1-2 generator & $\$ 400-800 k$ \\
\hline & $\begin{array}{l}\text { Compressor/driver, } \\
\text { piping, misc.* }\end{array}$ & $\begin{array}{c}\text { Base case set } \\
\text { to zero }\end{array}$ & $\$ 0$ & $\begin{array}{l}\text { Dependent on } \\
\text { design }\end{array}$ & $\$ 5-9 M M$ \\
\hline \multirow{2}{*}{$\begin{array}{l}x \\
w \\
\stackrel{a}{\circ}\end{array}$} & $\begin{array}{l}\text { Fuel for inert gas } \\
\text { generators }\end{array}$ & $\begin{array}{c}\text { Dual fuel } \\
\text { probably chosen }\end{array}$ & - & $\begin{array}{l}\text { Dual fuel still } \\
\text { required }\end{array}$ & - \\
\hline & Maintenance & $\begin{array}{l}\text { Base case set } \\
\text { to zero }\end{array}$ & $\$ 0$ & $\begin{array}{c}\text { More required } \\
\text { equipment }\end{array}$ & $\$ 100-200 k$ \\
\hline
\end{tabular}

\section{Cost effectiveness as a methane mitigation measure:}

The costs and benefits of HC blanketing is highly case specific.

For a number of installations, the solution has been justified from an economic and environmental perspective. The measure results in significant reductions of nmVOC emissions, which has been a priority for the oil and gas sector in Norway due to international commitments and industry agreements. Achieving methane reductions, while significant, has not been the main driver for the implemented projects. It would thus be misleading to present an abatement cost only for methane for this measure. Nevertheless, HC blanketing has contributed to avoiding significant emissions of methane from the oil and gas sector in Norway (roughly estimated at 2,600 tonnes $\mathrm{CH}_{4}$ in 2013 , equivalent to $11 \%$ of total reported $\mathrm{CH}_{4}$ emissions on the Norwegian continental shelf based on industry statistics). 


\section{Barriers and difficulties}

HC gas availability versus blanket gas requirements:

The main limitation of the use of the $\mathrm{HC}$ blanketing system is the minimum $\mathrm{HC}$ gas requirements to re-fill the storage tanks during offloading. DNV GL (ship and offshore classification, certification bodies) and SOLAS (International Convention for the Safety Of Life At $\mathrm{Sea}$ ) require a minimum blanket gas design rate of $125 \%$ of the maximum offloading rate. If a reservoir does not produce enough gas over its lifetime, the use of $\mathrm{HC}$ blanketing is challenging; the lifetime of the HC system might be limited, or HC blanketing blocked as an option. One FPSO with HC blanketing system installed had to revert to inert gas blanketing upon being moved from the Norwegian continental shelf to operate on a field on the UK continental shelf with limited gas production.

Process safety:

As long as proper care is taken in the design of pressure protection of the cargo tanks, HC gas used as blanket gas has been found to have no additional safety risks compared to the use of inert gas as blanket gas (according to DNV GL). There are three main issues regarding process safety and use of a $\mathrm{HC}$ blanketing system:

- High-pressure protection. New source for high pressure in the storage tanks during blanketing mode (but not a new scenario).

- Low pressure protection. New source for low pressure in the storage tanks during recovery mode (but not a new scenario).

- $100 \% \mathrm{HC}$ atmosphere in the storage tanks. Cargo and vent systems must be handled as a HC system even if inert blanket gas is used. In case of a trip of the recovery compressor, the vapors from the storage tanks needs to be vented to atmosphere (consisting of $100 \%$ hydrocarbons).

Operability issues:

Using $\mathrm{HC}$ gas as a gas-blanketing source is a step-change from normal operational practice for FPSOs. Getting acceptance from the crew using $\mathrm{HC}$ blanket gas has been reported as a challenge for the first Norwegian installations.

Introduction of more complexity could result in more process upsets and downtime. Some challenges associated with drainage of knock-out drums and condensate in headers have been presented by Statoil for HC blanketing at Norne FPSO. 
There are some influence of the existing process using a $\mathrm{HC}$ blanketing system. During oil offloading, HC gas to be used for blanketing is taken from the process. This reduces the flow of gas through the existing gas recompression train. Compressors must be able to handle the reduced flow. During recovery, HC gas emitted from the storage tanks is recovered back to the process. This increases the flow through the gas compression train resulting in a slightly increase in for example the gas export rate. It must be verified that the recompression train has sufficient capacity to compress the recovered tank emission in addition to the gas from the crude stabilization process.

\section{Contact information}

$\mathrm{HC}$ blanketing installations on FPSOs in the Nordic region:

\begin{tabular}{ccccc}
\hline Oil field: & FPSO: & Operator: & Skid capacity: & Start-up: \\
\hline Åsgard A & Åsgard FPSO & Statoil & & 1999 \\
Norne & Norne FPSO & Statoil & $2,800 \mathrm{~m} 3 / \mathrm{hr}$ & 2002 \\
Balder & Balder FPSO & ExxonMobile & $709 \mathrm{~m} 3 / \mathrm{hr}$ & 2004 \\
Jotun & Jotun FPSO & ExxonMobile & $2,082 \mathrm{~m} 3 / \mathrm{hr}$ & 2004 \\
Varg & Petrojarl Varg & Talisman & $750 \mathrm{~m} 3 / \mathrm{hr}$ & 2004 \\
Alvheim & Alvheim FPSO & Marathon & $1,500 \mathrm{~m} 3 / \mathrm{hr}$ & 2008 \\
Skarv & Skarv FPSO & BP & $2,286 \mathrm{~m} 3 / \mathrm{hr}$ & 2012 \\
Goliat & Goliat FPSO & ENI & $2,280 \mathrm{~m} 3 / \mathrm{hr}$ & Construction \\
Knarr & Knarr FPSO & BG Norge & $1,250 \mathrm{~m} 3 / \mathrm{hr}$ & Construction \\
\hline
\end{tabular}

HC blanketing systems for these FPSOs (except Åsgard A) have been delivered by:

Wärtsilä Oil \& Gas Systems AS

P.O. Box 144, 1371 Asker

Main: +47 66109500 Web: www.wartsila.com

Contact person: Stig TAndersen 


\section{Authors comment}

During the research and work with this paper many measures, techniques and ideas have been found. The specified selection criteria and input from external experts made it possible to narrow the vast number of generally listed measures down to the 14 selected case studies presented in this catalogue. At the same time many measures did not make it through the selection process and this not only because they do not fit as good examples. Especially in the ruminant livestock category several interesting measures had to be ruled out because they have not yet reached implementation phase. Also in the oil and gas sector it is the authors believe several more methane reduction measures can be presented in only a year or two. By then a large Norwegian governmental project on the theme (conducted by the Norwegian Environmental Agency) will hopefully be completed.

Since one of the conditions stated in the tender was that the measures should be technical the selection criteria was reviewed to exclude measures which can be categorized as economic or political instruments.

The demand that every measures should be implemented has drastically reduced the number of measures of relevance for the catalogue especially within the ruminant livestock category. The selection criteria also have a large impact on the rest of the identified measures since methane abatement have received more focus only over recent years. Many projects have thus just started or measurements for background data is still on going.

The sector wetland has been reviewed and found not to be relevant for the catalogue and therefore measure from this sector is not included in the catalogue. Landscaped wetlands have shown to be a relatively small contributor to anthropogenic emissions of methane. Studies have shown that the methane emission rates in waste water ponds are of the same magnitude as methane emissions from lakes in temperate regions. (Stadmark, Leonardson, 2005).

A conclusion from a review made on studies of wetland research is that the environmental benefits from nitrogen removal in wetlands are greater than the environmental impact from methane emissions. Although it would be of interest to implement measures to reduce methane emission if possible, no research on such measures has been found. After speaking with Johanna Stadmark, Researcher Lund University, the only measure that came to mind is to consider the 
location of the wetland. Studies have shown that amount of methane released is limited by substrate availability; temperature and nitrate are of less importance (Stadmark, Leonardson, 2007). It is thus concluded that measures for reducing methane emissions from landscaped wetlands are of minor interests for the methane catalogue and have not be studied further in this project.

As the issue of methane reduction has come into focus during the last years it is likely for most of the studied sectors that many interesting solutions and innovations are yet to be developed or discovered. When performing this study it is our opinion there are several more measures coming within just a few years. 


\section{References}

Bertilsson,J. (2014) Telephone conversation with Jenny Cerruto, 23 January

Blom, A. (2014) Telephone conversation with Maria Nilsson, 04 June

Broberg A. 2013, Innovatum. Pumpning av gödsel och biogas i markledning

Carbon Limit (2012) Best practice for reduction of methane and black carbon from arctic oil and gas productions. Commissioned by the Ministry of Environment in Norway.

Cederberg et. al. 2009. Greenhouse gas emissions from Swedish production of meat, milk and eggs 1990 and 2005. SIK

Environment Agency of Iceland, (2013) National Inventory Report Sweden 2013, Emissions of greenhouse gases in Iceland from 1990-2011 - Submitted under the United Nations Framework Convention on Climate Change and the Kyoto Protocol, Source: Swedish Greenhouse Gas Inventory, submission 2013 to the UNFCCC. Available at: http://unfccc.int/national_reports/ annex_i_ghg_inventories/national_inventories_submissions/ items/7383.php

Eksvärd, J. (2014) Telephone conversation with Jenny Cerruto, 14 February

Food and agriculture organization of the United Nations FAO. 2013b. Tackling climate change trough livestock.

Gerber, P.J, Henderson, B. and Makkar, P.S (2013) Mitigation of greenhouse gas emissions in livestock production - A review of technical options for non- $\mathrm{CO}_{2}$ emissions, $177 \mathrm{FAO}$ Animal production and health paper, Food and agriculture organization of the United Nations

Gode, J., Martinsson, F., Hagberg, L., Öman, A., Höglund, J. and Palm, D. (2011) Miljöfaktaboken 2011 Uppskattade emissionsfaktorer för bränslen, el, värme och transporter, Värmeforskning, Anläggnings- och förbränningsteknik 1183.

Gryaab (2013) Gryaabs verksamhet 2013 Available at: http://www.gryaab.se/arsredovisning2013/

Holmgren M.A, Hellström H., Petersson A., Blom A. (2012) The Swedish Voluntary Agreement for control of methane emissions from biogas plants, SP Technical Research Institute of Sweden and Swedish Waste Management Association.

IEA BIOENERGY (2014) Task 37 Biogas Country Overview, Available at: http://www.iea-biogas.net/files/daten-redaktion/ download/publications/country-reports/november2013/ Countryreport2013.pdf

I'Ons, D. (2014) Telephone conversation with Maria Nilsson, 17 June Lövendahl, P. (2014), Telephone conversation with Jenny Cerruto, 28 January

Norwegian Oil and Gas Association (2013) MILJØRAPPORT 2013 -

Olje- og Gassindustriens miljöarbeid fakta og utviklingstrekk. 
Available at: http://www.norskoljeoggass.no/Documents/ Miljørapport\%202013/NOROG\%20miljørapport13_NO_web_ mar14.pdf

Norwegian Environmental Agency. 2013. Foreløpig Sektorrapport Underlagsrapport til Forslag til handlingsplan for norske utslipp av kortlevde klimadrivere. Rapport M90/2013.

Paulsson, R. (2014) Email to Jenny Cerruto, 6 February

Pedersen R. (2012), Reduktion af metanemissionen fra Klintholm losseplads ved etablering af biocover.

Persson, M. (2014) Telephone conversation with Maria Nilsson, 10 June

Rodhe, I., Ascue, J., Tersmeden, M., Willén, A., Nordberg, Å., Salomon, E. and Sundberg, M. (2013) Växthusgaser från rötad och orötad nötflytgödsel vid lagring och efter spridning

Stadmark J, Leonardson L. (2005) Emission of greenhouse gases from ponds constructed for nitrogen removal. Lund University

Stadmark J, Leonardson L. (2007) Greenhouse gas production in a pond sediment: Effects of temperature, nitrate, acetate and season. Lund University

Statistics Denmark (2014), Emissions by Industry and type, Available at: http://www.statbank.dk/MRU1

Statistics Finland (2014) Distribution of main methane emissions in Finland 2011 Available at http://www.stat.fi/til/tilma/2011/ tilma_2011_2013-09-26_tau_005_en.html

Statistisk sentralbyrå (2014) Metan, utslipp, Available at http://www.miljostatus.no/Tema/Klima/Klimanorge/ Utslipp-av-klimagasser/Metan-CH4-utslipp/

Swedish Environmental Protection Agency (2013) National Inventory Report Sweden 2013, Greenhouse Gas Emission Inventories 1990-2011 - Submitted under the United Nations Framework Convention on Climate Change and the Kyoto Protocol, Source: Swedish Greenhouse Gas Inventory, submission 2013 to the UNFCCC. Available at: http://unfccc.int/national_reports/ annex_i_ghg_inventories/national_inventories_submissions/ items/7383.php

Swedish Board of Agriculture (2009) Växthusgaser från jordbruket Uppsala Vatten (2011) Biogasanläggningen vid Kungsängens gård, Available at: http://www.uppsalavatten.se/Documents/ Gemensam/Informationsmaterial/Anl\%C3\%A4ggningar/ Biogasanlaggning_Kungsangensgard_webb.pdf

\section{Websites}

http://www.miljostatus.no/Tema/Klima/Klimanorge/Utslippav-klimagasser/Metan-CH4-utslipp/

http://www.stat.fi/til/tilma/2011/tilma_2011_2013-09-26_ tau_005_en.html

http://www.statbank.dk/MRU1 
http://unfccc.int/national_reports/annex_i_ghg_inventories/

national_inventories_submissions/items/7383.php

http://www.sjugardar.se

http://www.slu.se/lovsta

http://naturbruk.nu/sv/Startsida/Skolorna/Sotasen/Miljo--

Utveckling/JTI-projekt/

http://www.swedishbiogas.com/index.php/sv/

referensanlaeggningar/sverige/katrineholm

http://www.trollhattanenergi.se/Page.asp?Pageld=209

http://www.sorpa.is/en

http://www.cambi.no/wip4/plant.epl?cat=10643\&id=190983

http://www.uppsalavatten.se/omoss/Anlaggningar/

Avfallsanlaggningar/Biogasanlaggning/

http://www.nsr.se/Default.aspx?ID=864

http://www.avfallsverige.se/avfallshantering/biologiskaatervinning/roetning/frivilligt-aatagande/

http://www.upplandsvasby.se/2/bygga-bo-och-miljo/avfall-ochatervinning/sortering-och-atervinning/matavfall.html

http://www.uppsalavatten.se/Documents/Gemensam/ Informationsmaterial/Anl\%C3\%A4ggningar/Biogasanlaggning_ Kungsangensgard_webb.pdf 
norden

Nordic Council of Ministers

Ved Stranden 18

DK-1061 Copenhagen K

www.norden.org 